Air plasma kinetics under the influence of sprites

This article has been downloaded from IOPscience. Please scroll down to see the full text article.

2008 J. Phys. D: Appl. Phys. 41234016

(http://iopscience.iop.org/0022-3727/41/23/234016)

View the table of contents for this issue, or go to the journal homepage for more

Download details:

IP Address: 161.111.22.141

The article was downloaded on 11/12/2012 at $11: 33$

Please note that terms and conditions apply. 


\title{
Air plasma kinetics under the influence of sprites
}

\author{
F J Gordillo-Vázquez ${ }^{1}$ \\ Instituto de Óptica, CSIC, Serrano 121, 28006 Madrid, Spain \\ E-mail: vasquez@io.cfmac.csic.es
}

Received 7 May 2008, in final form 25 June 2008

Published 20 November 2008

Online at stacks.iop.org/JPhysD/41/234016

\begin{abstract}
A full time-dependent kinetic study is presented for the main microscopic collisional and radiative processes underlying the optical flashes associated with an impulsive ( $\tau=5 \mu \mathrm{s})$ discharge in the form of a single sprite streamer passing through an air region of the mesosphere at three different altitudes $(63,68$ and $78 \mathrm{~km})$. The kinetic formalism developed includes the coupling of the rate equations of each of the different species considered (electrons, ions, atoms and molecules) with the Boltzmann transport equation so that, in this way, all the kinetics is self-consistent, although, in the present approach, the electrodynamics (no Poisson equation is considered) is not coupled. The chemical model set up for air plasmas includes more than 75 species and almost 500 reactions. In addition, a complete set of reactions (more than 110) has been considered to take into account the possible impact of including $\mathrm{H}_{2} \mathrm{O}$ (humid chemistry) in the generated air plasmas. This study also considers the vibrational kinetics of $\mathrm{N}_{2}$ and $\mathrm{CO}_{2}$ and explicitly evaluates the optical emissions associated with a number of excited states of $\mathrm{N}_{2}, \mathrm{O}_{2}, \mathrm{O}$ in the visible, $\mathrm{CO}_{2}$ in the infrared (IR) and ultraviolet (UV) emissions of sprite streamers due to the $\mathrm{N}_{2}$ Lyman-Birge-Hopfield ( $\mathrm{LBH}$ ) and the NO- $\gamma$ band systems. All the calculations are conducted for midnight conditions in mid-latitude regions $\left(+38^{\circ} \mathrm{N}\right)$ and $0^{\circ}$ longitude, using as initial values for the neutral species those provided by the latest version of the Whole Atmosphere Community Climate Model (WACCM). According to our calculations, the impact of $4 \mathrm{ppm}$ of $\mathrm{H}_{2} \mathrm{O}$ is only slightly visible in $\mathrm{O}_{3}^{-}$at 68 and $78 \mathrm{~km}$ while it strongly affects the behaviour of the anion $\mathrm{CO}_{4}^{-}$at all the altitudes investigated. The local enhancement of $\mathrm{NO}_{x}$ predicted by the present model varies with the altitude. At $68 \mathrm{~km}$, the concentrations of $\mathrm{NO}$ and $\mathrm{NO}_{2}$ increase by about one order of magnitude while that of $\mathrm{NO}_{3}$ exhibits a remarkable growth of up to almost three orders of magnitude. The variation of the $\mathrm{O}_{3}$ density predicted by the model in the sprite streamer head is negligible in all the altitudes investigated. The analysis of the time dependence of the electron distribution function (EDF) in the sprite plasma during the pulse reveals that the EDF transient is quite fast, reaching its 'steady' values during the pulse in less than $100 \mathrm{~ns}$ (much shorter than streamer head lifetimes). In addition, the calculated EDF during the pulse and in the afterglow is far from being Maxwellian, especially for energetic electrons (with $\varepsilon>30 \mathrm{eV}$ ). Finally, the evaluation of the mid-latitude nighttime electrical conductivity of air plasmas under the influence of a single sprite event reveals an increase of up to four orders of magnitude (at $68 \mathrm{~km}$ ) above its measured background level of $10^{-11} \mho \mathrm{v} \mathrm{cm}^{-1}$ at an altitude of $\sim 70 \mathrm{~km}$. This sudden increase in the electrical conductivity lasts for $100 \mathrm{~ms}$ (at $68 \mathrm{~km})$, being shorter $(\sim 1 \mathrm{~ms})$ and longer $(1 \mathrm{~s})$ at $63 \mathrm{~km}$ and $78 \mathrm{~km}$, respectively. The total power delivered by the streamer head of a single sprite event has been estimated to be approximately $1677 \mathrm{~W}$ (at $78 \mathrm{~km}$ ), $230 \mathrm{~kW}$ (at $68 \mathrm{~km}$ ) and $78 \mathrm{MW}$ (at $63 \mathrm{~km}$ ).
\end{abstract}

(Some figures in this article are in colour only in the electronic version)

\section{Introduction}

1 Present address: Instituto de Astrofisica de Andalucia, CSIC, Apdo. 3004, 18008 Granada, Spain.
The so-called transient luminous events (TLEs) are large scale optical flashes taking place at altitudes that go from approximately 50 to $90 \mathrm{~km}$, that is, they occur at stratospheric 
and mesospheric altitudes, and they originate as a consequence of the electrical activity in underlying thunderstorms as predicted in 1925 by Wilson [1]. Of the various types of TLEs, the so-called sprites $[2,3]$, which are weakly ionized plasmas, are the most commonly detected since their first recording in 1989 [4]. Later on, in 1994, the first colour images of sprites were taken from a plane [5] and their characteristic red and blue emission features were clearly observed for the first time. Since then, many sprite observations from the ground have taken place all over the world [6-11]. In 1992, the first space observation of sprites was performed during thunderstorm observations from the Space Shuttle [12-14]. The optical measurements resulting from sprite emissions detected with the lightning and sprite observations (LSO) experiments running between 2001 and 2004 in the International Space Station (ISS) were reported in 2004 [15]. The results from the MEIDEX experiment onboard the Space Shuttle provided new sprite observations from the space [16]. More recently, ISUAL, the first sprite experiment onboard a satellite, was launched in May 2004 and has been providing many visible and ultraviolet (UV) spectral data on sprites since then [17-20]. The future missions TARANIS [21] and ASIM [22] are expected to produce more insights and understanding of sprites in a wider region of the electromagnetic spectrum. More recently, telescopic imaging of sprites has revealed a great variety of spatial and temporal scales suggesting a preliminary approach to the time scales of streamer-like structures in sprites and demonstrating that they exhibit a highly nonuniform altitude structure characterized by a lower $(50-70 \mathrm{~km})$ streamer-like region and a higher diffuse region (70-90 km) [10,23-26]. The latter together with very recent high-speed video recordings [27-29] of the sprite temporal development illustrates the sprite streamer dynamics and its remarkable similarity [30] to the streamers formed within different types of gas discharges produced at ground pressure [31].

The earliest spectroscopic observations of sprites [32,33], performed with low temporal $(15-30 \mathrm{~ms})$ and spectral resolution $(6-9 \mathrm{~nm})$, were only able to identify the $\mathrm{N}_{2}$ first positive band system $\left(1 \mathrm{PN}_{2}\right)\left(B^{3} \Pi_{\mathrm{g}} \rightarrow A^{3} \Sigma_{\mathrm{u}}^{+}\right)$as the most important optical emission feature in the sprite spectra resolved from 460 to $800 \mathrm{~nm}$. These initial studies did not detect any features associated with the $\mathrm{N}_{2}^{+}\left(A^{2} \Pi_{\mathrm{u}} \rightarrow X^{2} \Sigma_{\mathrm{g}}^{+}\right)$Meinel band, the $\mathrm{N}_{2}^{+}$(1NG) $\left(B^{2} \Sigma_{\mathrm{u}}^{+} \rightarrow X^{2} \Sigma_{\mathrm{g}}^{+}\right)$first negative group or other optical emissions, like the $\mathrm{N}_{2}$ second positive band system $\left(2 \mathrm{PN}_{2}\right)\left(C^{3} \Pi_{\mathrm{u}} \rightarrow B^{3} \Pi_{\mathrm{g}}\right)$ and the first negative band of $\mathrm{O}_{2}^{+}$, expected (all of them) to be the most intense during the interaction of electromagnetic pulses from lightning with the lower ionosphere [34,35]. Later studies [36] have shown that, assuming a distribution of intensities of different wavelengths within the $1 \mathrm{PN}_{2}$ band similar to the one observed in auroral emissions, the $\mathrm{N}_{2}$ first and second positive bands seem to be primarily responsible for the largest red and blue signals in video recordings of sprites [5]. The latter has been confirmed by UV/blue spectrum of sprites observed at $65 \mathrm{~km}$ [37].

In addition to the $\mathrm{N}_{2}$ second positive band system, blue optical emissions from sprites have also been associated with the radiative de-excitation of $\mathrm{N}_{2}^{+}\left(B^{2} \Sigma_{\mathrm{u}}^{+}\right)$previously excited in collisions with electrons [38-40]. Blue emission from $\mathrm{N}_{2}^{+}$originates from the lower (tendrils) region of sprites and is produced during the initial stages of sprite formation, not usually being detectable in temporally integrated spectra [39].

Recent analyses have also shown that, in addition to the $1 \mathrm{PN}_{2}$ features, the higher-altitude sprite spectrum also shows the presence of some peaks associated with the $\mathrm{N}_{2}^{+}$ Meinel band which are hardly visible in the lower-altitude spectrum [41]. The confirmation of the presence of $\mathrm{N}_{2}^{+}$in sprites, through the detection of blue emissions from the $1 \mathrm{NG}$ of $\mathrm{N}_{2}^{+}$, was a remarkable result since it was an indication that excited ionized species were also produced in sprites in addition to the neutral emissions found in the early red observations. The latter suggests that the average electron energies needed to produce the observed sprite spectra are above $0.5-2 \mathrm{eV}$ predicted by preliminary spectral analysis providing information on the vibrational distributions of the excited $\mathrm{N}_{2}\left(B^{3} \Pi_{\mathrm{g}}\right)$ state [41-44]. In addition to visible emissions, sprites can also emit in the IR and UV parts of the electromagnetic spectrum [18]. The IR and UV emissions come from excited species such as $\mathrm{CO}_{2}, \mathrm{~N}_{2}$, $\mathrm{NO}$ and/or $\mathrm{N}_{2}^{+}$. However, IR and UV are usually strongly absorbed by $\mathrm{H}_{2} \mathrm{O}$ (IR emissions) and $\mathrm{O}_{2}$ (UV emissions). The latter makes it difficult to conduct IR and UV observations from the ground or even using planes. In spite of this, there are some early studies about the modelling of IR emission from sprites and its possible detection from space $[45,46]$. In the same way, two recent works have presented modelling studies of NO- $\gamma$ (UV) and LBH (far UV) emissions of sprite streamers showing that, at $70 \mathrm{~km}$ altitude, the total gamma emissions from the excited $\mathrm{NO}$ are considerably smaller than those due to $\mathrm{N}_{2} \mathrm{LBH}$ emissions $[47,48]$. Consequently, while LBH emissions due to sprites have already been detected by ISUAL [49] and compared with streamer modelling [18], the detection of NO- $\gamma$ emissions from space has not yet been reported because it requires a narrower bandwidth spectrophotometer than the $130 \mathrm{~nm}$ bandpass photometer $(150-280 \mathrm{~nm})$ presently installed in ISUAL [20].

All the above spectroscopic data about sprite emissions in different wavelength ranges have given us valuable information about the important excited species that are able to radiate. However, the final chemical impact of TLE and, in particular, of sprites in the surrounding upper atmosphere is not yet well understood. Recent data by ISUAL have revealed that, between 40 and $60 \mathrm{~km}$, the average electron energies and reduced electric field producing the optical spectra recorded from sprites change between 6.2-9.2 eV and between 243 and $443 \mathrm{Td}$, respectively, that is, the sustaining electric field takes a value between 2.1 and 3.7 times that of the atmosphere breakdown field $\left(E_{k}\right)$ at these altitudes [17]. It is possible that these energetic electrons under the action of such high electric fields might create highly chemical reactive species (such as, for instance, $\mathrm{NO}_{x}$ ) that can induce local changes in the background chemical composition of the mesosphere [50,51]. Thus, one active line of research nowadays focuses on understanding the ability of sprite discharges and postdischarge air plasma chemistries to locally produce nitride oxides such as $\mathrm{NO}_{x}\left(\mathrm{NO}, \mathrm{NO}_{2}\right)$ and $\mathrm{N}_{2} \mathrm{O}$. These oxides 
are important since they provide catalytic pathways for the destruction of ozone and participate in the oxidation of a number of chemical species in the stratosphere. The local perturbations of $\mathrm{NO}$ and $\mathrm{O}_{3}$ concentrations due to a single blue jet event (a type of TLE) have been modelled following a kinetic approach showing an enhancement of $10 \%$ and $0.5 \%$ at $30 \mathrm{~km}$ altitude [52]. However, such enhancements in the upper atmosphere have rarely been reported and there are only a few observational studies [53,54].

The earliest studies [53,55] reporting results on the chemistry of sprites used the kinetic approach typically used to investigate the plasma chemistry associated with gas discharges produced in different types of plasma reactors. Later on, a reduced set of electron-driven reactions has been used to predict a significant enhancement of metastable oxygen atoms $\mathrm{O}\left({ }^{1} \mathrm{D}\right)$ in the mesosphere associated with the sprite chemical activity [56]. Very recently, at the beginning of 2008, three different works were published (or sent to publication) incorporating complex chemical schemes in order to undertake the kinetic modelling of the chemical effects of sprites during nighttime conditions in the middle and upper atmosphere [57-59]. While two of them predict fractional enhancements of $50 \%$ for $\mathrm{NO}$ at $70 \mathrm{~km}$ [57] and $\mathrm{NO}_{x}$ at $73 \mathrm{~km} \mathrm{[58],} \mathrm{the} \mathrm{third} \mathrm{one} \mathrm{[59]} \mathrm{predicts} \mathrm{an} \mathrm{increase} \mathrm{in} \mathrm{the}$ NO concentration of four orders of magnitude above its background level at $70 \mathrm{~km}$. These differences might be due to the initial conditions chosen, the uncertainty in the reaction rate coefficients and the number of kinetic processes considered. The results from two of the previously mentioned models [58, 59] can be compared with a very recent study [60] reporting $\mathrm{NO}_{2}$ nighttime mid-infrared $\left(680-2410 \mathrm{~cm}^{-1}\right)$ measurements from the Michelson interferometer for passive atmospheric sounding (MIPAS) instrument onboard the ESA satellite ENVISAT. Results shown in [60] indicate a possible sprite induced $\mathrm{NO}_{2}$ enhancement of about $10 \%$ at $52 \mathrm{~km}$ altitude with a trend to increase with height from a few per cent at $47 \mathrm{~km}$ to tens of per cent at $60 \mathrm{~km}$. The latter agrees with the predictions of the ion-neutral chemical model reported in [58], but is far from the $\mathrm{NO}_{2}$ enhancement of two orders of magnitude at $50 \mathrm{~km}$ altitude predicted by another recent model based on ion-neutral reactions to explain the chemistry of sprite discharges [59].

This paper is an attempt to contribute to the general understanding of the non-equilibrium plasma chemistry triggered by sprite streamers in the Earth mesosphere and its possible impact in the local chemical composition of the upper atmosphere. In doing so, this work describes a kinetic approach used to evaluate the temporal evolution of the concentrations of a number of important chemical species created while sprite discharges are occurring and during their afterglows. A quantitative analysis is also performed of the most important microscopic processes underlying the sprite chemical activity at three different altitudes $(63,68$ and $78 \mathrm{~km})$. In addition, the model predicts the emission brightness of sprites associated not only with visible radiative transitions but also with other important ones emitting in the UV (NO- $\gamma, \mathrm{LBH}$ and the $2 \mathrm{PN}_{2}$ system) and IR (from vibrationally excited $\mathrm{CO}_{2}$ and the $1 \mathrm{PN}_{2}$ system) regions of the electromagnetic spectrum that could be detected from the space.
The structure of this paper consists of a preliminary description of the used model approach and its basic equations followed by the different kinetic processes taken into consideration (section 2). Later on, in section 3, a detailed enumeration of the main results obtained is accompanied by a discussion of the most important findings reported. Finally, the conclusions are presented in section 4 . In addition, this paper also includes an extensive appendix where the reader can find all the reactions and their rate coefficients considered in the chemical scheme proposed for modelling the non-equilibrium air plasma chemistry associated with single sprite events.

\section{Model approach}

The approach followed in this work assumes that the main chemical activity of sprites originates in their brightest regions, that is, in their short living streamer heads recently observed during very high-speed $\left(10^{4} \mathrm{fps}\right)$ video recordings [28, 29]. Recent $(100 \mu \mathrm{s}$ average $)$ measurements by the ISUAL instrument onboard the FORMOSAT- 2 satellite have shown that the average electron energies in the luminous regions of sprites are between 6.2 and $9.2 \mathrm{eV}$ [17]. This finding suggests that, in a first stage, electrons are capable of generating a considerable degree of excitation and ionization in the low temperature air plasmas confined within the streamer tips and, consequently, a considerable number of atmospheric species can become chemically active through electron-driven reactions. The timescale of the streamer heads is connected to their dimensions and speed [61] which, according to recent measurements of speeds between 1 and $6 \times 10^{7} \mathrm{~m} \mathrm{~s}^{-1}$ associated with $25 \mathrm{~m}$ streamer heads [29], suggest a temporal duration of several microseconds. The reduced electric field $E / N$ underlying the brightest sprite optical emissions has recently been estimated by the ISUAL instrument by studying $2 \mathrm{PN}_{2} / 1 \mathrm{NN}_{2}^{+}$ratios of several sprites observed between altitudes of 40 and $60 \mathrm{~km}$ and the reported $E / N$ fields range between 243 and $443 \mathrm{Td}\left(2.1-3.7 E_{k} / N\right.$, where $E_{k} / N \cong 121 \mathrm{Td}$ is the atmosphere breakdown reduced electric field and $N$ is the gas density) [17]. The upper limit of the $E / N$ values reported in [17] is in agreement with the electric field magnitudes $\left(>3 E_{k} / N\right)$ predicted in recent models of sprite streamers [18].

\subsection{Model equations and numerical procedure}

The basic model equations controlling the non-equilibrium air plasma chemistry of sprite streamers are

$$
\frac{\partial n_{i}}{\partial t}=G-L,
$$

which represents a set of differential rate equations for each of the chemical species of type $i$ in the streamer plasma where $n_{i}$ stands for the concentration of the atomic and molecular neutrals, ions (positive and negative) and free electrons that can change as a consequence of the gain $(G)$ and loss $(L)$ kinetic processes taking place during and after the short time pulse that the electric field is on within the streamer head. The microscopic processes considered in $G$ and $L$ include the 
chemistry of neutral and ions together with the electron-driven kinetics. In this regard, the rate coefficients of each of the electron-driven reactions considered need to be calculated by using appropriate sets of cross sections and the corresponding electron distribution function in each time step. In order to do these calculations as accurately as possible, equation (1) has been coupled to a time-dependent and spatially uniform Boltzmann transport equation of the form

$$
\left(\frac{\partial}{\partial t}+\frac{e E(t)}{m_{\mathrm{e}}} \cdot \nabla_{\mathrm{v}}\right) f(v, t)=\left(\frac{\partial f}{\partial t}\right)_{\text {collisions }},
$$

where $f(v, t)$ is the distribution function for free electrons at time $t$ with speed $v$ whose relation to their kinetic energy is simply $\varepsilon=1 / 2 m v^{2}$. The symbols $e, m_{\mathrm{e}}, E$ and $\nabla_{\mathrm{v}}$ stand for the electric charge and mass of electrons, the electric field within the streamer head and the velocity gradient operator, respectively. The coupling between equations (1) and (2) comes through the collision term on the right-hand side of equation (2) which represents the rate of change in $f(v, t)$ due to different kinds of collisions. This term also includes the densities of neutrals (atom and molecules) and ions in the plasma. In this study, the electron collisions considered are elastic, inelastic and superelastic ones. It is worth mentioning that electron-electron collisions, that is, Coulomb collisions, are not included because sprite plasmas have low electron densities and, consequently, Coulomb collisions only play a negligible role in the kinetics of this plasma so that they can be safely disregarded. Finally, a condition of macroscopic electrical neutrality is imposed so that the net charge balance in the plasma is zero (quasi-neutral plasma) in each time step. Therefore, the solutions of the system of equations (1) and (2) need to satisfy that

$$
\sum_{j} n_{j}^{+}=n_{\mathrm{e}}+\sum_{k} n_{k}^{-}
$$

where $n_{j}^{+}, n_{k}^{-}$and $n_{\mathrm{e}}$ stand for the concentrations of all the positive and negative ions and free electrons in the plasma, respectively. In order to solve equation (2), the program ELENDIF [62] was used as a subroutine called by a chemical kinetics code that integrates the stiff system of differential equations (1) in successive time steps. As time progresses, the electron distribution function is recomputed and new rate coefficients are calculated so that the electron and ion concentrations fulfil the condition imposed by equation (3). The numerical integrator used by our kinetic model is the updated version of the Livermore solver for ordinary differential equations (LSODE) [63,64], which is the basic solver of the ODEPACK collection of FORTRAN solvers for the initial value problem of ODE systems. This series of solvers can be freely downloaded from LLNL [65]. In particular, LSODE solves the initial value problem of stiff and nonstiff systems of first order ODEs of the form

$$
\frac{\mathrm{d} y}{\mathrm{~d} t}=g(t, y) .
$$

For stiff problems, the LSODE solver uses the backward differentiation formula (BDF) method (the Gear method) [66].
The BDF method is particularly convenient for solving a highly nonlinear set of differential equations since it has the property of stiff stability [66] and therefore does not suffer, as the popular explicit Runge-Kutta and Adams methods, from the stability step size constraint once the concentrations of the fast chemical components in the plasma have decayed to negligible values.

\subsection{Model assumptions, parameters and initial conditions}

The kinetic formalism adopted includes the coupling of the rate equations of each of the different species considered (electrons, ions, atoms and molecules) with the Boltzmann equation so that, in this way, all of the kinetics is self-consistent, although, in the present approach, the electrodynamics (no Poisson equation is considered) is not self-consistently solved with the plasma kinetics. In this regard, it has been assumed that the reduced electric field $(E / N)$ within the streamer head plasma is an external parameter of the model and that it exhibits a step-like shape, that is, $E / N=400 \mathrm{Td}\left(\sim 3.3 E_{k} / N\right)$ during a short time interval of $t_{\mathrm{p}}=5 \mu \mathrm{s}$ while, afterwards, $E=1 \mathrm{Td}$. The low field value after the pulse is characteristic of the afterglow region recently observed behind sprite streamer heads [28] so that the electron-driven kinetics becomes of secondary importance when compared with the processes controlled by the collisions between heavy species. Another important assumption of this model is related to the noninclusion of photochemistry processes in spite of the fact that some photochemical mechanisms, such as photoionization, might have some importance in the propagation and branching of sprite streamers $[67,68]$ but with an indirect influence on the non-equilibrium chemistry of the streamer plasma.

For a typical pressure $\left(4.45 \times 10^{-5} \mathrm{~atm}\right)$ and gas temperature $\left(T_{\mathrm{g}} \sim 220 \mathrm{~K}=0.0189 \mathrm{eV}\right)$ of the altitudes where sprite streamers develop, the diffusion coefficient of neutrals is about $3000 \mathrm{~cm}^{2} \mathrm{~s}^{-1}$, while in a non-thermal $\left(\varepsilon_{k} \neq\right.$ $\left.T_{\mathrm{g}}=T_{\text {ion }}\right)$ quasi-neutral plasma, the ambipolar diffusion coefficient $\left(D_{\mathrm{a}} \cong D_{+} \times\left(1+\varepsilon_{k} / T_{\text {ion }}\right)\right)$ of electrons and ions reaches the value of $1.94 \times 10^{5} \mathrm{~cm}^{2} \mathrm{~s}^{-1}$ [69], where $\varepsilon_{k}$ is the characteristic electron energy, $D_{+}$is the diffusion coefficient of positive ions $\left.\left(D_{ \pm}=D_{ \pm}^{0} / p\right) \times\left(T_{\mathrm{g}} / 273\right)^{2}\right)$ and $T_{\text {ion }}$ is the ion temperature [69]. Therefore, the time needed by neutrals and charged particles (electrons and ions) to move through a typical streamer radius $(\sim 12.5 \mathrm{~m})$ is $\sim 6.5 \mathrm{~s}$ and $\sim 520 \mathrm{~s}$, respectively. However, these timescales are usually longer than those of the kinetic reactions controlling the concentrations of electrons and most of the ions and neutrals and, consequently, the densities of most of the species have decayed to negligible values before their transport by diffusion starts to be noticeable. Therefore, in the present approach, the transport of electrons and ions by diffusion has not been considered. In evaluating the ambipolar diffusion coefficient above, one needs to first evaluate the characteristic electron energy, $\varepsilon_{k}=D_{\mathrm{T}} / \mu_{\mathrm{e}}$, where $\mu_{\mathrm{e}}=v_{\mathrm{d}} / E$ is the electron mobility, $v_{\mathrm{d}}$ is the electron drift velocity and $D_{\mathrm{T}}$ is the electron transverse diffusion coefficient. These magnitudes $\left(D_{\mathrm{T}}, \mu_{\mathrm{e}}\right)$ have been calculated once the electron distribution function (EDF) is obtained from the solutions of the system of equations (1)-(3). Thus, it 
was found that $\varepsilon_{k}=5.76 \mathrm{eV}$ which is lower than the value of the electron mean energy $\langle\varepsilon\rangle=7.86 \mathrm{eV}$ obtained while the streamer reduced sustaining field $E / N=400 \mathrm{Td}$ is on. The values of both $\varepsilon_{k}$ and $\langle\varepsilon\rangle$ are within the experimental range inferred from the ISUAL recorded sprites [17]. Strictly speaking, in non-thermal and non-equilibrium plasmas with electron kinetics driven by a non-Maxwellian EDF, as those of sprite streamers, the concept of 'electron temperature' $\left(T_{\mathrm{e}}\right)$ cannot be properly defined. If the EDF were Maxwellian, $\varepsilon_{k}=D_{\mathrm{T}} / \mu_{\mathrm{e}}=2 / 3\langle\varepsilon\rangle$ with $\langle\varepsilon\rangle=3 / 2 T_{\mathrm{e}}$. However, in our case, $\varepsilon_{k}=5.76 \mathrm{eV} \neq T_{\mathrm{e}}=5.24 \mathrm{eV}$.

Some words are needed to justify the use of ELENDIF, a conventional two-term Boltzmann solver, rather than a multiterm procedure or a Monte Carlo simulation. The use of the Lorentz (two-term) approach in the case of $\mathrm{N}_{2}$-containing plasmas can be questionable due to the relative importance of some inelastic processes (vibrational excitation) when compared with elastic collisions. However, the inclusion, as in our case, of superelastic collisions with vibrationally excited $\mathrm{N}_{2}$ molecules contribute to decreasing the possible influence of vibrational excitation on the EDF and, consequently, the twoterm expansion can still be considered a good approximation in $\mathrm{N}_{2}$-containing plasmas [69].

Finally, the present calculations have been carried for three different altitudes of $63 \mathrm{~km}\left(T_{\mathrm{g}}=240 \mathrm{~K}\right), 68 \mathrm{~km}$ $\left(T_{\mathrm{g}}=220 \mathrm{~K}\right)$ and $78 \mathrm{~km}\left(T_{\mathrm{g}}=200 \mathrm{~K}\right)$. It is assumed the same $E / N=400 \mathrm{Td}$ in the three altitudes investigated. In addition, all the calculations are conducted for midnight conditions in mid-latitude regions $\left(+38^{\circ} \mathrm{N}\right)$ and $0^{\circ}$ longitude, using as initial values for the neutral species listed in appendix A those provided by the latest version of the Whole Atmosphere Community Climate Model (WACCM) based on the National Center for Atmospheric Research's Community Atmospheric Model (CAM). The latest version of the model, WACCM3, is derived from CAM3 and includes all the physical parametrizations of that model. A complete description of CAM3 is given in [70] where details are given about the governing equations, physical parametrizations and numerical algorithms. The reader is also referred to the CAM web site for more information [71].

\subsection{Chemical species and kinetic reactions}

The chemical species considered in this work are listed in tables 1-4. We have taken into consideration a total of 77 species classified into ground neutrals (23), excited neutrals (24), electrons and negative ions (15) and positive ions (15). The exact number of reactions considered is 486 , where there are electron-driven reactions (90), neutral-neutral reactions (222), ion-ion recombination mechanisms (36), ion-neutral processes (127, with 53 positive ion-neutral mechanisms and 74 negative ion-neutral reactions) and radiative deexcitation channels (11). The complete list of all the reactions considered and their corresponding rate coefficients is shown in appendix B. There are 45 electron-impact reactions indicated as EDF-dependent processes for which their rate coefficients are not shown because they are self-consistently calculated using the cross section data convoluted with the
Table 1. Ground neutrals considered

\begin{tabular}{l}
\hline Ground neutrals \\
\hline $\mathrm{N}, \mathrm{N}_{2}, \mathrm{O}, \mathrm{O}_{2}, \mathrm{O}_{3}$ \\
$\mathrm{NO}, \mathrm{NO}_{2}, \mathrm{NO}_{3}, \mathrm{~N}_{2} \mathrm{O}, \mathrm{N}_{2} \mathrm{O}_{5}$ \\
$\mathrm{H}_{2} \mathrm{O}, \mathrm{H}, \mathrm{OH}, \mathrm{H}_{2}, \mathrm{HO}_{2}$ \\
$\mathrm{H}_{2} \mathrm{O}_{2}, \mathrm{HNO}_{x}(x=1,2,3)$ \\
$\mathrm{CO}, \mathrm{CO}_{2}, \mathrm{HCO}, \mathrm{Ar}$ \\
\hline
\end{tabular}

Table 2. Excited neutrals considered.

\begin{tabular}{l}
\hline Excited neutrals \\
\hline $\mathrm{N}_{2}\left(A^{3} \Sigma_{\mathrm{u}}^{+}, B B^{3} \Pi_{\mathrm{g}}, C^{3} \Pi_{\mathrm{u}}, a^{1} \Pi_{\mathrm{g}}, a^{\prime 1} \Sigma_{\mathrm{u}}^{-}\right)$ \\
$\mathrm{O}_{2}\left(a^{1} \Delta_{\mathrm{g}}, b^{1} \Sigma_{\mathrm{g}}^{+}\right), \mathrm{O}\left({ }^{1} \mathrm{D},{ }^{1} \mathrm{~S}\right)$ \\
$\mathrm{NO}\left(A^{2} \Sigma^{+}\right), \mathrm{N}\left({ }^{2} \mathrm{D},{ }^{2} \mathrm{P}\right), \operatorname{Ar}\left({ }^{3} \mathrm{P}\right)$ \\
$\mathrm{CO}_{2}(001,010,100)$ \\
$\mathrm{N}_{2}\left(X^{1} \Sigma_{\mathrm{g}}^{+}(v=1, \ldots, v=8)\right)$ \\
\hline
\end{tabular}

Table 3. Electrons and negative ions considered.

\begin{tabular}{l}
\hline Negative ions \\
$\mathrm{e}, \mathrm{O}^{-}, \mathrm{O}_{2}^{-}, \mathrm{O}_{3}^{-}$ \\
$\mathrm{NO}^{-}, \mathrm{NO}_{2}^{-}, \mathrm{NO}_{3}^{-}$ \\
$\mathrm{H}^{-}, \mathrm{OH}^{-}, \mathrm{H}_{2} \mathrm{O}_{2}^{-}, \mathrm{H}_{2} \mathrm{O}_{3}^{-}, \mathrm{H}_{2} \mathrm{O}_{4}^{-}, \mathrm{H}_{3} \mathrm{O}_{2}^{-}$ \\
$\mathrm{CO}_{3}^{-}, \mathrm{CO}_{4}^{-}$ \\
\hline
\end{tabular}

Table 4. Positive ions considered.

\begin{tabular}{l}
\hline Positive ions \\
\hline $\mathrm{N}_{2}^{+}, \mathrm{N}_{2}^{+}\left(B^{2} \Sigma_{\mathrm{u}}^{+}\right), \mathrm{N}_{4}^{+}$ \\
$\mathrm{O}^{+}, \mathrm{O}_{2}^{+}, \mathrm{O}_{3}^{+}, \mathrm{O}_{4}^{+}$ \\
$\mathrm{NO}^{+}, \mathrm{NO}_{2}^{+}, \mathrm{N}_{2} \mathrm{O}^{+}, \mathrm{N}_{2} \mathrm{O}_{2}^{+}$ \\
$\mathrm{H}_{2} \mathrm{O}^{+}, \mathrm{H}_{3} \mathrm{O}^{+}, \mathrm{OH}^{+}$ \\
$\mathrm{Ar}^{+}$ \\
\hline
\end{tabular}

time-dependent electron distribution function derived from the solution of the Boltzmann equation coupled to all the rate equations as explained in sections 2.1 and 2.2. The reference source of the cross sections and/or rates used for each reaction is indicated in the last column of each of the tables.

In addition, we have included, when available, the gas temperature range of validity of the rate coefficients. The rate coefficients were taken from 45 different bibliographic sources [72-117]; roughly $42 \%$ of all of them were taken from references [69] (20\%) and [83] (22\%). The electron-impact reactions include a variety of processes such as ionization and dissociative ionization, dissociation, two and threebody attachment, electron-ion recombination, dissociative excitation and electronic and vibrational excitations. The radiative de-excitation processes shown at the end of appendix B include their Einstein coefficients $(A)$ for spontaneous emission, the wavelength $(\lambda)$ of the lines emitted in each of the spontaneous radiative decays considered and the plasma optical thickness $(\kappa)$ for that wavelength. For simplicity, the latter has been assumed to be one; that is, the plasma is assumed to be optically thin and, therefore, no radiation is re-absorbed. Finally, a set of 115 reactions associated with the non-equilibrium chemistry of the humid air plasma has also been taken into consideration. This is important because $\mathrm{H}$-containing species (especially the $\mathrm{OH} / \mathrm{H}$ 


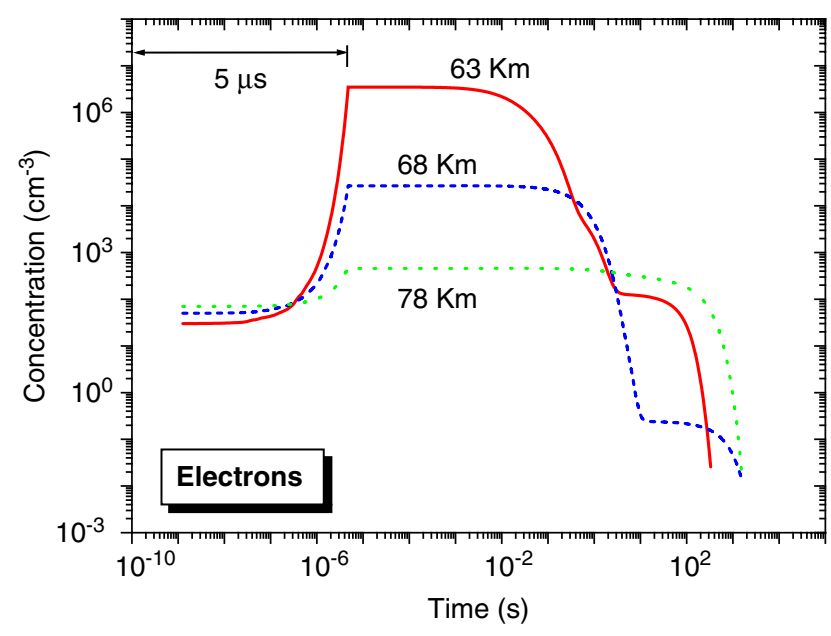

Figure 1. Time-dependent behaviour of the concentration of electrons $\left(N_{\mathrm{e}}\right)$ produced by a sudden electric pulse of $5 \mu \mathrm{s}$ in air plasmas containing $4 \mathrm{ppm}$ of $\mathrm{H}_{2} \mathrm{O}$ under the conditions of a single sprite event for three different altitudes. The solid lines are for an altitude of $63 \mathrm{~km}$, the dashed line indicates $N_{\mathrm{e}}$ for $68 \mathrm{~km}$ and the dotted line corresponds to the case of $78 \mathrm{~km}$.

chemistry) together with negative ions and nitride oxides might have some influence on the final concentrations of ozone. We have assumed a constant amount of $\mathrm{H}_{2} \mathrm{O}$ in the region investigated $(63-78 \mathrm{~km})$ equal to $4 \mathrm{ppm}$. The reprocessed water vapour data from the halogen occultation experiment (HALOE) onboard the Upper Atmosphere Research Satellite (UARS) shows an unusual enhancement in $\mathrm{H}_{2} \mathrm{O}$ of up to a maximum of $7 \mathrm{ppm}$ around an altitude of $67 \mathrm{~km}$. However, HALOE measurements also indicate that the water vapour sharply decreases below and above $67 \mathrm{~km}$, being $3 \mathrm{ppm}$ at $78 \mathrm{~km}$ and around $6 \mathrm{ppm}$ at $63 \mathrm{~km}$ [118].

\section{Results and discussion}

\subsection{Electrons and electrical conductivity}

The main results of this work are shown in figures 1-36. We will start this section by commenting on the behaviour of the electron density shown in figure 1 . The results presented in figure 1 indicate that, depending on the altitude, the electron density can reach values of up to $10^{6} \mathrm{~cm}^{-3}(63 \mathrm{~km})$ or remain in relatively low values hardly above $10^{2} \mathrm{~cm}^{-3}(78 \mathrm{~km})$ after the sprite event. It is interesting to note that, even after the end of the electric pulse that generates the sprite, the electron density shows relatively high values $\left(>10^{3} \mathrm{~cm}^{-3}\right)$ at 63 and $68 \mathrm{~km}$ for almost $100 \mathrm{~ms}$. The kinetic model used 42 gain reactions channels leading to the growth of the electron density and 43 processes that contribute to the removal of electrons. Before the end of the electric pulse $(<5 \mu \mathrm{s})$, the main production of electrons is due to electron-impact ionization processes (in decreasing order of importance):

$$
\begin{aligned}
& \mathrm{P} 16: \mathrm{N}_{2}+\mathrm{e} \rightarrow \mathrm{N}_{2}^{+}+2 \mathrm{e}, \\
& \text { P21 }: \mathrm{O}_{2}+\mathrm{e} \rightarrow \mathrm{O}_{2}^{+}+2 \mathrm{e}, \\
& \mathrm{P} 17: \mathrm{N}_{2}+\mathrm{e} \rightarrow \mathrm{N}_{2}^{+}\left(B^{2} \Sigma_{\mathrm{u}}^{+}\right)+2 \mathrm{e}, \\
& \mathrm{P} 49: \mathrm{e}+\mathrm{O}_{2} \rightarrow \mathrm{O}^{+}+\mathrm{O}+2 \mathrm{e}, \\
& \mathrm{P} 2: \mathrm{Ar}+\mathrm{e} \rightarrow \mathrm{Ar}^{+}+2 \mathrm{e} .
\end{aligned}
$$

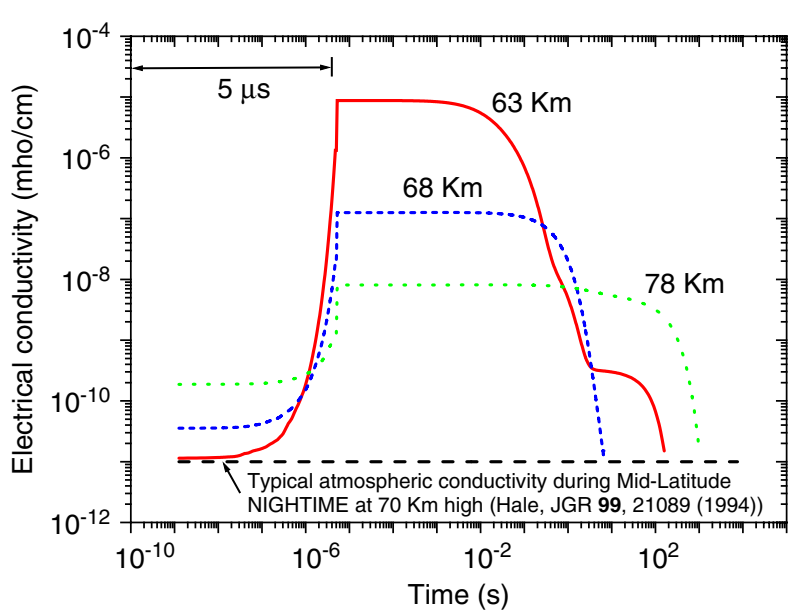

Figure 2. Time-dependent behaviour of the electronic component (dominant) of the electrical conductivity enhancement of air plasmas containing $4 \mathrm{ppm}$ of $\mathrm{H}_{2} \mathrm{O}$ due to a single sprite event.

However, the loss of electrons during the pulse $(<5 \mu \mathrm{s})$ is mainly due to two-body electron attachment to $\mathrm{O}_{2}$ :

$$
\text { P57 : } \mathrm{O}_{2}+\mathrm{e} \rightarrow \mathrm{O}^{-}+\mathrm{O} \text {. }
$$

When the pulse is over $(>5 \mu \mathrm{s})$, the electrons are produced mainly by electron detachment processes of $\mathrm{O}^{-}$with $\mathrm{N}_{2}$ :

$$
\text { P314: } \mathrm{O}^{-}+\mathrm{N}_{2} \rightarrow \mathrm{N}_{2} \mathrm{O}+\mathrm{e},
$$

although the electron detachment of $\mathrm{O}^{-}$with $\mathrm{O}_{2}$ and with $\mathrm{O}_{3}$, $\mathrm{H}_{2}$ and $\mathrm{CO}$ is also of some importance:

$$
\begin{aligned}
& \mathrm{P} 315: \mathrm{O}^{-}+\mathrm{O}_{2} \rightarrow \mathrm{O}_{3}+\mathrm{e}, \\
& \text { P320: } \\
& \text { P454: } \mathrm{O}^{-}+\mathrm{O}_{3} \rightarrow 2 \mathrm{O}_{2}+\mathrm{e}, \\
& \text { P328: } \mathrm{O}^{-}+\mathrm{CO} \rightarrow \mathrm{HO}_{2}+\mathrm{e},
\end{aligned}
$$

At $63 \mathrm{~km}$, the main loss channels of electrons after $(>5 \mu \mathrm{s})$ the pulse are mechanisms of electron dissociative recombination with $\mathrm{N}_{2} \mathrm{O}_{2}^{+}$ions and electron attachment:

$$
\begin{aligned}
& \text { P86 : e }+\mathrm{N}_{2} \mathrm{O}_{2}^{+} \rightarrow \mathrm{NO}+\mathrm{NO}, \\
& \text { P87 : e }+\mathrm{N}_{2} \mathrm{O}_{2}^{+} \rightarrow \mathrm{N}_{2}+\mathrm{O}_{2}, \\
& \text { P57 : e }+\mathrm{O}_{2}+\mathrm{O}_{2} \rightarrow \mathrm{O}_{2}^{-}+\mathrm{O}_{2}, \\
& \text { P26 : } \mathrm{O}_{3}+\mathrm{e} \rightarrow \mathrm{O}^{-}+\mathrm{O}_{2} .
\end{aligned}
$$

However, at 68 and $78 \mathrm{~km}$, after the pulse, the electrons are mainly removed by

$$
\mathrm{P} 81: \mathrm{e}+\mathrm{O}^{+}+\mathrm{e} \rightarrow \mathrm{O}+\mathrm{e} \text {. }
$$

The plot in figure 2 shows the electrical conductivity (in $\mho \mathrm{cm}^{-1}$ ) of the air plasma produced by a single sprite event. At an altitude above $\sim 60 \mathrm{~km}$, the electron component of the electrical conductivity is usually dominant over the ionic component [36]. Therefore, we have calculated the electrical conductivity for 63,68 and $78 \mathrm{~km}$ using the results from our kinetic model. The expression used for the electron component $\sigma_{e}$ is given by

$$
\sigma_{\mathrm{e}}=Q_{\mathrm{e}} N_{\mathrm{e}} \mu_{\mathrm{e}},
$$

where $Q_{\mathrm{e}}$ is the electronic charge, $N_{\mathrm{e}}$ is the electron number density and $\mu_{\mathrm{e}}$ is the electron mobility. The latter is equal to 
$v_{\mathrm{d}} / E$, where $v_{\mathrm{d}}$ is the electron drift velocity and $E$ is the electric field strength. The values of $N_{\mathrm{e}}$ and $v_{\mathrm{d}}$ are obtained as outputs of the kinetic model. Thus, we have that $v_{\mathrm{d}}(400 \mathrm{Td})=2.674 \times$ $10^{5} \mathrm{~m} \mathrm{~s}^{-1}$ and $v_{\mathrm{d}}(1 \mathrm{Td})=4.41 \times 10^{3} \mathrm{~m} \mathrm{~s}^{-1}$. Therefore, since $E$ depends on the altitude, we have different electron mobilities for the different altitudes and for the glow and afterglow regions. Thus, at $63 \mathrm{~km}, \mu_{\mathrm{e}}(400 \mathrm{Td})=237.3 \mathrm{~m}^{2} \mathrm{~s}^{-1} \mathrm{~V}^{-1}$ and $\mu_{\mathrm{e}}(1 \mathrm{Td})=1567.3 \mathrm{~m}^{2} \mathrm{~s}^{-1} \mathrm{~V}^{-1}$; at $68 \mathrm{~km}, \mu_{\mathrm{e}}(400 \mathrm{Td})=$ $442.7 \mathrm{~m}^{2} \mathrm{~s}^{-1} \mathrm{~V}^{-1}$ and $\mu_{\mathrm{e}}(1 \mathrm{Td})=2923.8 \mathrm{~m}^{2} \mathrm{~s}^{-1} \mathrm{~V}^{-1}$ and at $78 \mathrm{~km}, \mu_{\mathrm{e}}(400 \mathrm{Td})=1671.2 \mathrm{~m}^{2} \mathrm{~s}^{-1} \mathrm{~V}^{-1}$ and $\mu_{\mathrm{e}}(1 \mathrm{Td})=$ $11057.5 \mathrm{~m}^{2} \mathrm{~s}^{-1} \mathrm{~V}^{-1}$.

The flat dashed line at the bottom represents the background air conductivity during mid-latitude nighttime conditions as reported in [119]. The other lines are as in figure 1 .

We can see in figure 2 that, in the first moments $\left(<10^{-7} \mathrm{~s}\right)$ during the electric pulse, the electrical conductivity at $68 \mathrm{~km}$ is quite close to the typical nighttime air conductivity in midlatitude regions at $70 \mathrm{~km}$ high as reported by Hale [119] and represented in figure 2 as a flat dashed line. The plot in figure 2 of the mid-latitude nighttime electrical conductivity of air plasmas under the influence of a single sprite event reveals an increase of up to four orders of magnitude (at $68 \mathrm{~km}$ ) above its measured background level of $10^{-11} \mathrm{~J} \mathrm{~cm}^{-1}$ at an altitude of $70 \mathrm{~km}$ [119]. This sudden increase in the electrical conductivity lasts for almost $100 \mathrm{~ms}$ at $68 \mathrm{~km}$, being shorter $(\sim 1 \mathrm{~ms})$ and longer $(1 \mathrm{~s})$ at $63 \mathrm{~km}$ and $78 \mathrm{~km}$, respectively. The remarkable enhancement of the electrical conductivity due to the sprite chemical activity could be traced during its relatively long duration $(100 \mathrm{~ms}$ at $68 \mathrm{~km})$ and, if experimentally detected, could be used as an alternative way to determine the importance of the sprite chemical activity in the mesosphere. Once we know from figure 2 the maximum enhancement of the electrical conductivities, we can roughly estimate the total electric power delivered to the surrounding atmosphere by the streamer head of a single sprite event occurring at different altitudes. The ohmic power density $\left(\mathrm{W} \mathrm{m}^{-3}\right)$ dissipated by a single streamer head is simply $\sigma_{\mathrm{e}}\left(\mathrm{mho} \mathrm{m}^{-1}\right) \times E^{2}\left(\mathrm{~V}^{2} \mathrm{~m}^{-2}\right)$ where, for times $\leqslant 5 \mu \mathrm{s}, E=$ $400 \mathrm{Td} \times N$ (gas density at the different altitudes considered). If the streamer head is assumed to be of spherical shape with a radius of $25 \mathrm{~m}$, its total volume delivering power is $65000 \mathrm{~m}^{3}$. Therefore, the total power delivered by the streamer head of a single sprite event would be approximately $1677 \mathrm{~W}$ (at $78 \mathrm{~km}$ ), $230 \mathrm{~kW}$ (at $68 \mathrm{~km}$ ) and $78 \mathrm{MW}$ (at $63 \mathrm{~km}$ ).

\subsection{Analysis of the electron distribution function}

The electron distribution function (EDF) plays a key role in driving the electron kinetics of sprite plasmas. In this section a brief analysis is provided on the temporal evolution of the EDF during the pulse and after it, that is, during the afterglow. The normalization condition chosen for the EDF is

$$
\int_{0}^{\infty} \sqrt{\varepsilon} f(\varepsilon) \mathrm{d} \varepsilon=1,
$$

where $\varepsilon$ stands for the electron energy and $f(\varepsilon)$ is the EDF. Once the EDF is calculated, the mean electron energy, transport
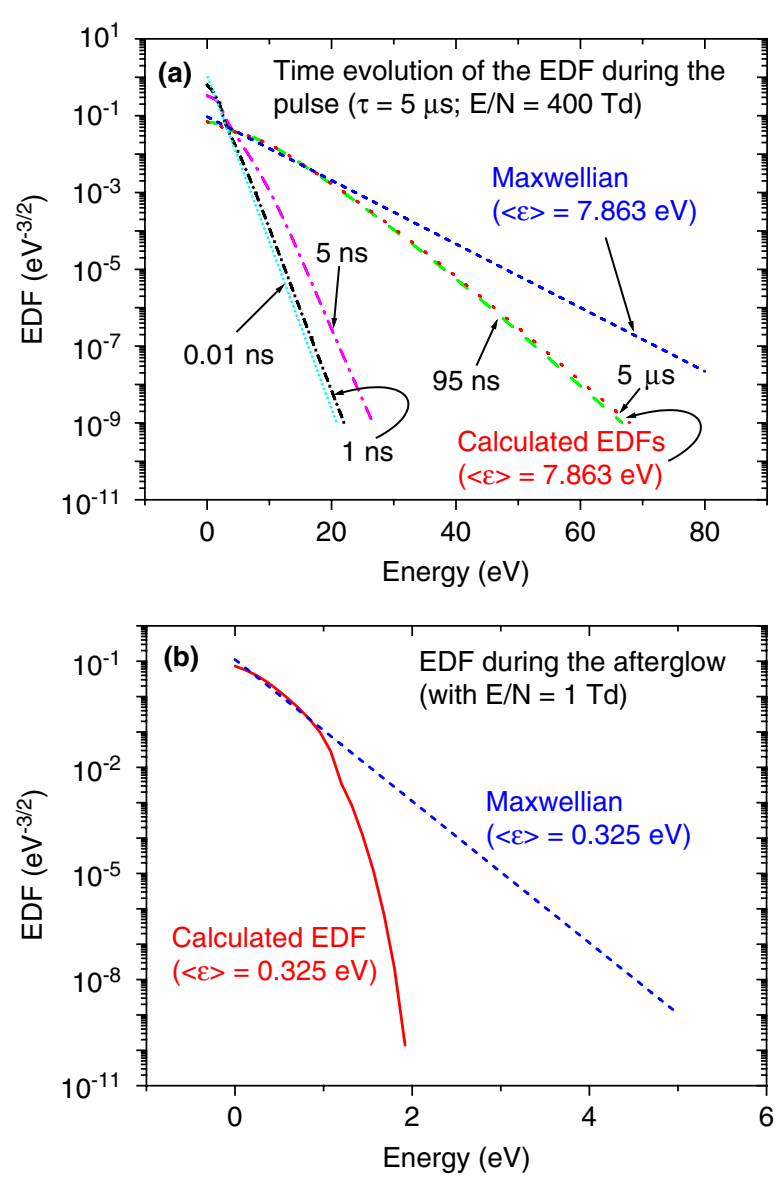

Figure 3. (a) Time-dependent behaviour of the calculated electron distribution function (EDF) during the pulse at different time steps (0.01 ns-short dotted line; $1 \mathrm{~ns}$ - short dashed dotted line;

$5 \mathrm{~ns}$-dashed dotted line; $95 \mathrm{~ns}$-dashed line; $5 \mu \mathrm{s}$-dotted line) and Maxwellian EDF (upper dashed line). (b) Steady values of the calculated EDF (solid line) and Maxwellian EDF (dashed line) in the afterglow of a sprite plasma.

and rate coefficients can be quantified. The plots in figure 3(a) show the variation with time of the calculated EDF during the pulse (from $0.01 \mathrm{~ns}$ up to $5 \mu \mathrm{s}$ ) when $E / N=400 \mathrm{Td}$. We can clearly see that the EDF transient is quite fast, usually below $100 \mathrm{~ns}$. The latter is the time needed by the EDF to reach its steady values while the pulse is on. In addition, a plot is also included of a Maxwellian EDF (with the same electron mean energy as that of the calculated steady EDF during the pulse) so that the deviation of the calculated EDF from the Maxwellian one can be clearly observed (upper dashed line in figure 3(a)). This deviation becomes more and more important as the electron energy increases. We can conclude from figure 3(a) that, in order to study the electron kinetics, it is really not crucial to follow in time the EDF since its timescale (relaxation times) is much shorter (nanoseconds) than that of streamer head lifetimes (microseconds). Thus, it would be enough to consider the steady state EDF (dotted line in figure 3(a) marked with the $5 \mu$ s label) during the pulse.

The steady-state value of the calculated EDF when the pulse is over (afterglow) is represented in figure $3(b)$ together with a Maxwellian EDF for the same electron mean energy. Figure $3(b)$ shows the non-negligible deviation of 


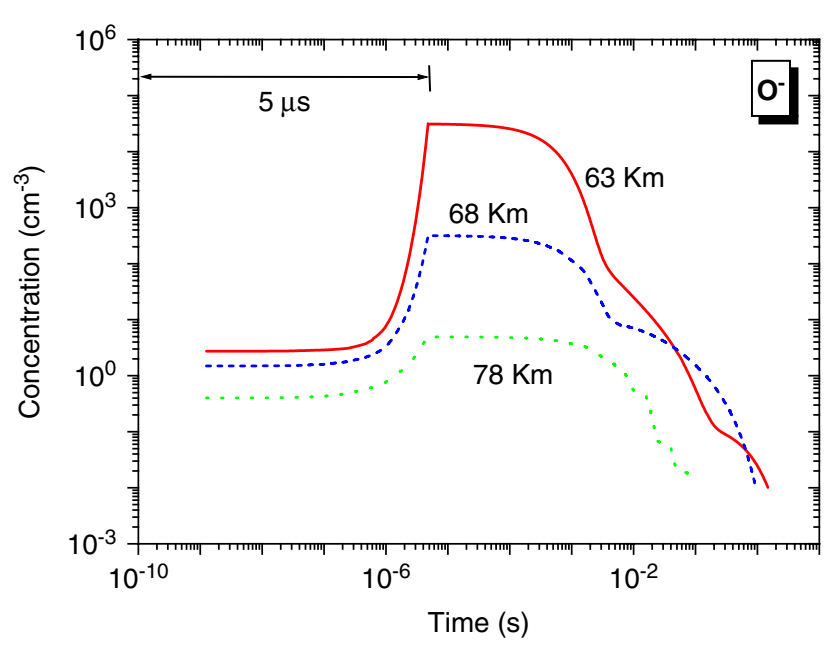

Figure 4. Time-dependent behaviour of the concentration of $\mathrm{O}^{-}$ ions under the conditions of a single sprite event for three different altitudes. The lines indicate the same as in figure 1 .

the calculated EDF from the Maxwellian for the low reduced electric field used ( $1 \mathrm{Td}$ ). For higher fields ( 25 or $50 \mathrm{Td}$ ) the departure of the EDF from the Maxwellian would be lower.

\subsection{Negative ions}

In figure 4, we can see the time evolution of the concentration of $\mathrm{O}^{-}$ions. The trend followed is the same for the three altitudes investigated and its highest value is reached at $63 \mathrm{~km}$ right at the end $(5 \mu \mathrm{s})$ of the electric pulse going through the air plasma and similarly to the predicted behaviour of the electron density. It is also visible that $\mathrm{O}^{-}$decreases by almost four orders of magnitude as the altitude increases from 63 to $78 \mathrm{~km}$. The main kinetic mechanism controlling the production of $\mathrm{O}^{-}$before the end of the electric pulse $(<5 \mu \mathrm{s})$ is electron dissociative attachment of $\mathrm{O}_{2}$ :

$$
\mathrm{P} 25: \mathrm{e}+\mathrm{O}_{2} \rightarrow \mathrm{O}^{-}+\mathrm{O},
$$

followed in order of importance by electron dissociative attachment of $\mathrm{CO}_{2}, \mathrm{O}_{3}$ and $\mathrm{H}_{2} \mathrm{O}$ :

$$
\begin{aligned}
& \mathrm{P} 45: \mathrm{e}+\mathrm{CO}_{2} \rightarrow \mathrm{CO}+\mathrm{O}^{-}, \\
& \mathrm{P} 26: \mathrm{e}+\mathrm{O}_{3} \rightarrow \mathrm{O}^{-}+\mathrm{O}_{2}, \\
& \mathrm{P} 41: \mathrm{e}+\mathrm{H}_{2} \mathrm{O} \rightarrow \mathrm{H}_{2}+\mathrm{O}^{-} .
\end{aligned}
$$

On the other hand, the losses of $\mathrm{O}^{-}$before $5 \mu$ s are mainly due to the detachment of $\mathrm{O}^{-}$in collisions with $\mathrm{N}_{2}$ molecules:

$$
\mathrm{P} 314: \mathrm{O}^{-}+\mathrm{N}_{2} \rightarrow \mathrm{N}_{2} \mathrm{O}+\mathrm{e},
$$

followed by a number of detachment processes (of similar importance) of $\mathrm{O}^{-}$with $\mathrm{O}_{2}, \mathrm{O}_{3}, \mathrm{H}_{2}$ and $\mathrm{CO}$ :

$$
\begin{aligned}
& \mathrm{P} 315: \mathrm{O}^{-}+\mathrm{O}_{2} \rightarrow \mathrm{O}_{3}+\mathrm{e}, \\
& \text { P320: } \mathrm{O}^{-}+\mathrm{O}_{3} \rightarrow 2 \mathrm{O}_{2}+\mathrm{e}, \\
& \text { P325: } \mathrm{O}^{-}+\mathrm{O}_{3} \rightarrow \mathrm{O}_{3}^{-}+\mathrm{O}, \\
& \text { P454: } \mathrm{O}^{-}+\mathrm{H}_{2} \rightarrow \mathrm{H}_{2} \mathrm{O}+\mathrm{e}, \\
& \text { P328: } \mathrm{O}^{-}+\mathrm{CO} \rightarrow \mathrm{CO}_{2}+\mathrm{e} .
\end{aligned}
$$

When the pulse is off (time $>5 \mu \mathrm{s}$ ), the $\mathrm{O}^{-}$ions are mainly generated due to electron dissociative attachment of $\mathrm{O}_{3}$ :

$$
\mathrm{P} 26: \mathrm{e}+\mathrm{O}_{3} \rightarrow \mathrm{O}^{-}+\mathrm{O}_{2} \text {. }
$$

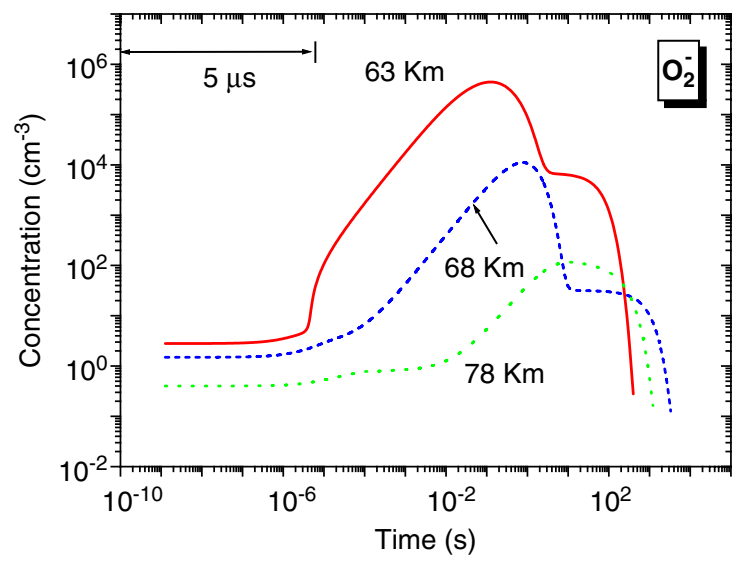

Figure 5. Time-dependent behaviour of the concentration of $\mathrm{O}_{2}^{-}$ ions under the conditions of a single sprite event for three different altitudes. The lines indicate the same as in figure 1.

In addition, processes such as electron $\mathrm{NO}_{2}$ dissociative attachment (P61 : e $\left.+\mathrm{NO}_{2} \rightarrow \mathrm{O}^{-}+\mathrm{NO}\right)$ and charge transfer $\left(\mathrm{P} 331: \mathrm{O}_{2}^{-}+\mathrm{O} \rightarrow \mathrm{O}^{-}+\mathrm{O}_{2}\right.$ ) play a secondary role in the production of $\mathrm{O}^{-}$at $63 \mathrm{~km}$ and $68 \mathrm{~km}$ and $78 \mathrm{~km}$, respectively. The loss of $\mathrm{O}^{-}$after the pulse is mainly connected to the action of

$$
\mathrm{P} 314: \mathrm{O}^{-}+\mathrm{N}_{2} \rightarrow \mathrm{N}_{2} \mathrm{O}+\mathrm{e},
$$

while a minor role is also played by reactions $\mathrm{P} 315: \mathrm{O}^{-}+$ $\mathrm{O}_{2} \rightarrow \mathrm{O}_{3}+\mathrm{e}$ at $63 \mathrm{~km}$ and $68 \mathrm{~km}$ and $\mathrm{P} 328: \mathrm{O}^{-}+\mathrm{CO} \rightarrow$ $\mathrm{CO}_{2}+\mathrm{e}$ at $78 \mathrm{~km}$.

The time evolution of the concentration of $\mathrm{O}_{2}^{-}$ions is shown in figure 5 . The trend followed by $\mathrm{O}_{2}^{-}$is the same for the three altitudes investigated and its highest value is reached at $63 \mathrm{~km}$. In general, the peak values of the $\mathrm{O}_{2}^{-}$concentration are found quite after the end of the igniting pulse producing the weakly ionized (but highly excited) non-equilibrium air plasma. The trend predicted is that the higher the altitude the lower the $\mathrm{O}_{2}^{-}$concentration and the more delayed (with respect to the pulse end) its peaked value in time. The main kinetic mechanism controlling the production of $\mathrm{O}_{2}^{-}$before the end of the electric pulse $(<5 \mu \mathrm{s})$ depends on the altitude. At $63 \mathrm{~km}$, the three-body electron attachment dominates:

$$
\mathrm{P} 57: \mathrm{e}+\mathrm{O}_{2}+\mathrm{O}_{2} \rightarrow \mathrm{O}_{2}^{-}+\mathrm{O}_{2} \text {. }
$$

However, charge transfer is the dominant production channel of $\mathrm{O}_{2}^{-}$at 68 and $78 \mathrm{~km}$ :

$$
\mathrm{P} 350: \mathrm{NO}^{-}+\mathrm{O}_{2} \rightarrow \mathrm{O}_{2}^{-}+\mathrm{NO}
$$

followed in importance by mechanisms of electron dissociative attachment P27: $\mathrm{O}_{3}+\mathrm{e} \rightarrow \mathrm{O}_{2}^{-}+\mathrm{O}$ and electron attachment P58 : e $+\mathrm{O}_{2}+\mathrm{N}_{2} \rightarrow \mathrm{O}_{2}^{-}+\mathrm{N}_{2}$ occurring at the three heights evaluated.

The losses of $\mathrm{O}_{2}^{-}$before $5 \mu \mathrm{s}$ at 63 and $68 \mathrm{~km}$ are mainly due to the charge transfer between $\mathrm{O}_{2}^{-}$and ozone molecules:

$$
\mathrm{P} 339: \mathrm{O}_{2}^{-}+\mathrm{O}_{3} \rightarrow \mathrm{O}_{2}+\mathrm{O}_{3}^{-},
$$

followed by ion recombination P261: $\mathrm{O}_{2}^{-}+\mathrm{O}_{2}^{+} \rightarrow \mathrm{O}_{2}+\mathrm{O}_{2}$ at $63 \mathrm{~km}$ and $\mathrm{P} 463: \mathrm{O}_{2}^{-}+\mathrm{H}_{2} \mathrm{O}+\mathrm{N}_{2} \rightarrow \mathrm{H}_{2} \mathrm{O}_{3}^{-}+\mathrm{N}_{2}$ at $68 \mathrm{~km}$. At $78 \mathrm{~km}$ high, the most important loss process is $\mathrm{P} 331$ : $\mathrm{O}_{2}^{-}+\mathrm{O} \rightarrow \mathrm{O}^{-}+\mathrm{O}_{2}$ followed by $\mathrm{P} 332: \mathrm{O}_{2}^{-}+\mathrm{O} \rightarrow \mathrm{O}_{3}+$ e. 


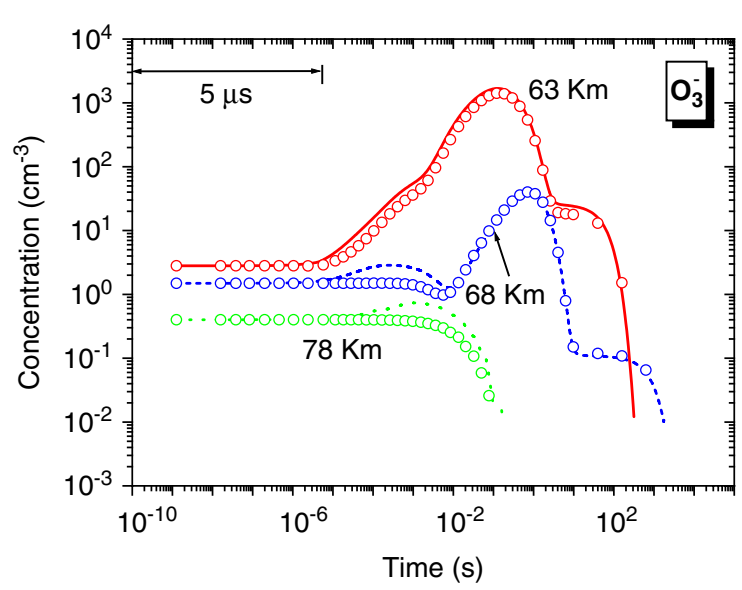

Figure 6. Time-dependent behaviour of the concentration of $\mathrm{O}_{3}^{-}$ ions under the conditions of a single sprite event for three different altitudes. The lines indicate the same as in figure 1 (with $4 \mathrm{ppm}$ of $\mathrm{H}_{2} \mathrm{O}$ ) and the open circles stand for the case of dry air plasmas.

Some time after the pulse (time $\sim 100 \mu \mathrm{s}$ ), the $\mathrm{O}_{2}^{-}$ions at 63 and $68 \mathrm{~km}$ are produced mainly by the three-body electron attachment P57 : e $+\mathrm{O}_{2}+\mathrm{O}_{2} \rightarrow \mathrm{O}_{2}^{-}+\mathrm{O}_{2}$ closely followed by $\mathrm{P} 27: \mathrm{O}_{3}+\mathrm{e} \rightarrow \mathrm{O}_{2}^{-}+\mathrm{O}$ and P58 $: \mathrm{e}+\mathrm{O}_{2}+\mathrm{N}_{2} \rightarrow \mathrm{O}_{2}^{-}+\mathrm{N}_{2}$, while at $78 \mathrm{~km}$, the charge transfer between $\mathrm{NO}^{-}$and $\mathrm{O}_{2}$ dominates (P350: $\left.\mathrm{NO}^{-}+\mathrm{O}_{2} \rightarrow \mathrm{O}_{2}^{-}+\mathrm{NO}\right)$. At a time close to the $\mathrm{O}_{2}^{-}$concentration peak (time $\sim 0.1 \mathrm{~s}$ ) at $63 \mathrm{~km}$, the mechanisms controlling the generation of $\mathrm{O}_{2}^{-}$at 63,68 and $78 \mathrm{~km}$ are still the same.

The loss of $\mathrm{O}_{2}^{-}$after the pulse at 63 and $68 \mathrm{~km}$ is mainly connected to the action of:

$$
\mathrm{P} 339: \mathrm{O}_{2}^{-}+\mathrm{O}_{3} \rightarrow \mathrm{O}_{2}+\mathrm{O}_{3}^{-},
$$

while at $78 \mathrm{~km}$ the most important $\mathrm{O}_{2}^{-}$depletion reaction is $\mathrm{P} 331: \mathrm{O}_{2}^{-}+\mathrm{O} \rightarrow \mathrm{O}^{-}+\mathrm{O}_{2}$ followed by P332: $\mathrm{O}_{2}^{-}+\mathrm{O} \rightarrow$ $\mathrm{O}_{3}+\mathrm{e}$.

The time evolution of the concentration of $\mathrm{O}_{3}^{-}$ions is shown in figure 6. In this case, we can see a slight influence of the air plasma humidity with respect to the dry case (plotted with open circles) in the rising region between $100 \mu \mathrm{s}$ and $0.01 \mathrm{~s}$ at 68 and $78 \mathrm{~km}$. The underlying reason for this behaviour is that, in a humid environment at say $1000 \mu \mathrm{s}$, the dominant process controlling the production of $\mathrm{O}_{3}^{-}$at 68 and $78 \mathrm{~km}$ is

$$
\text { P459: } \mathrm{H}_{2} \mathrm{O}_{2}^{-}+\mathrm{O}_{2} \rightarrow \mathrm{H}_{2} \mathrm{O}+\mathrm{O}_{3}^{-},
$$

while in the dry air plasma at the same heights ( 68 and $78 \mathrm{~km})$, the process $\mathrm{P} 325: \mathrm{O}^{-}+\mathrm{O}_{3} \rightarrow \mathrm{O}_{3}^{-}+\mathrm{O}$ drives the generation of $\mathrm{O}_{3}^{-}$. In the time domain $(\sim 0.1 \mathrm{~s})$ close to the maximum values of $\mathrm{O}_{3}^{-}$at 63 and $68 \mathrm{~km}$, the $\mathrm{O}_{3}^{-}$production mechanism that prevails is the charge transfer $\mathrm{P} 339: \mathrm{O}_{2}^{-}+\mathrm{O}_{3} \rightarrow \mathrm{O}_{2}+\mathrm{O}_{3}^{-}$. The disappearance of $\mathrm{O}_{3}^{-}$is principally controlled by $\mathrm{P} 349$ : $\mathrm{O}_{3}^{-}+\mathrm{CO}_{2} \rightarrow \mathrm{CO}_{3}^{-}+\mathrm{O}_{2}$ and also, but in a much less extension than P349, by P348: $\mathrm{O}_{3}^{-}+\mathrm{O}_{3} \rightarrow 3 \mathrm{O}_{2}+$ e.

Figure 7 shows the time-dependent behaviour of the ion $\mathrm{CO}_{3}^{-}$. The concentration of this negative ion remains quite low during the pulse and then, at around $1000 \mu \mathrm{s}$, its density begins to grow quite fast (at 63 and $68 \mathrm{~km}$ ) and slow at $78 \mathrm{~km}$ due to the relatively high production rate associated with the process

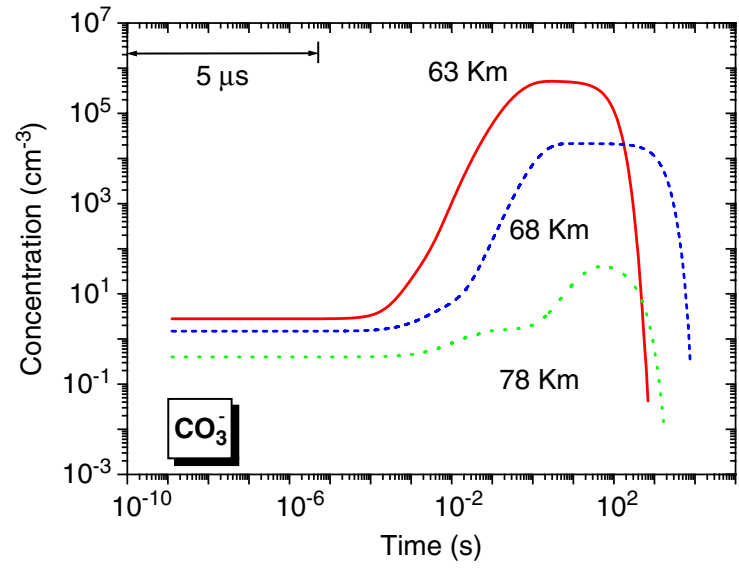

Figure 7. Time-dependent behaviour of the concentration of $\mathrm{CO}_{3}^{-}$ ions under the conditions of a single sprite event for three different altitudes. The lines indicate the same as in figure 1 .

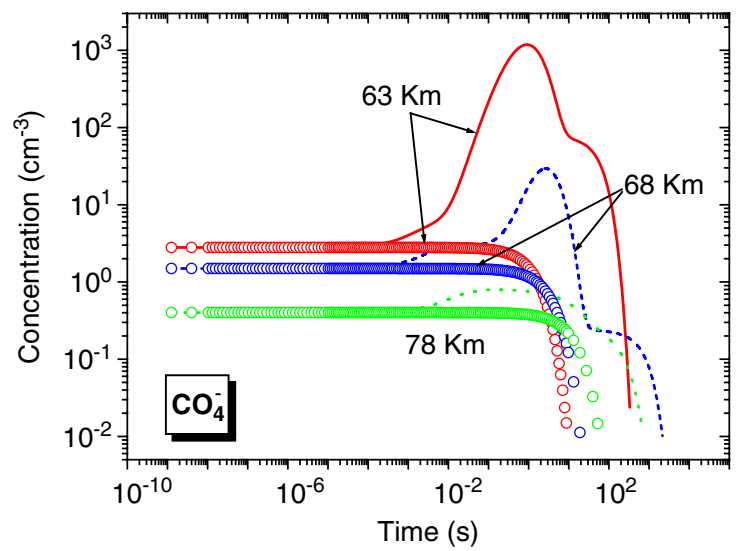

Figure 8. Time-dependent behaviour of the concentration of $\mathrm{CO}_{4}^{-}$ ions under the conditions of a single sprite event for three different altitudes. The lines indicate the same as in figure 1 (with $4 \mathrm{ppm}$ of $\mathrm{H}_{2} \mathrm{O}$ ) and the open circles stand for the case of dry air plasmas.

P349: $\mathrm{O}_{3}^{-}+\mathrm{CO}_{2} \rightarrow \mathrm{CO}_{3}^{-}+\mathrm{O}_{2}$ and that of the lower rate of $\mathrm{P} 473: \mathrm{H}_{2} \mathrm{O}_{4}^{-}+\mathrm{CO}_{2} \rightarrow \mathrm{CO}_{3}^{-}+\mathrm{H}_{2} \mathrm{O}+\mathrm{O}_{2}$ counterbalanced by reactions such as $\mathrm{P} 361: \mathrm{CO}_{3}^{-}+\mathrm{O} \rightarrow \mathrm{O}_{2}^{-}+\mathrm{CO}_{2}$ and $\mathrm{P} 363: \mathrm{CO}_{3}^{-}+\mathrm{NO}_{2} \rightarrow \mathrm{NO}_{3}^{-}+\mathrm{CO}_{2}$ with small removal rates.

The interesting case of $\mathrm{CO}_{4}^{-}$is shown in figure 8 . For $\mathrm{CO}_{4}^{-}$, the most important production channel $\mathrm{P} 474: \mathrm{H}_{2} \mathrm{O}_{3}^{-}+$ $\mathrm{CO}_{2} \rightarrow \mathrm{CO}_{4}^{-}+\mathrm{H}_{2} \mathrm{O}$ requires the presence of humidity in the environment. Reaction $\mathrm{P} 474$ is always important independently of the time domain analysed. When no water vapour is present, the only active channels are the loss ones P364: $\mathrm{CO}_{4}^{-}+\mathrm{O} \rightarrow \mathrm{CO}_{3}^{-}+\mathrm{O}_{2}$ and P365: $\mathrm{CO}_{4}^{-}+\mathrm{O}_{3} \rightarrow$ $\mathrm{O}_{3}^{-}+\mathrm{CO}_{2}+\mathrm{O}_{2}$.

\subsection{Positive ions}

In this section we describe the time-dependent behaviour of five out of the fifteen positive ions considered in this work. These five positive ions were chosen because of their representative value in providing an insight into the role played by positive ions in the non-equilibrium air plasma chemistry activated by sprites. 


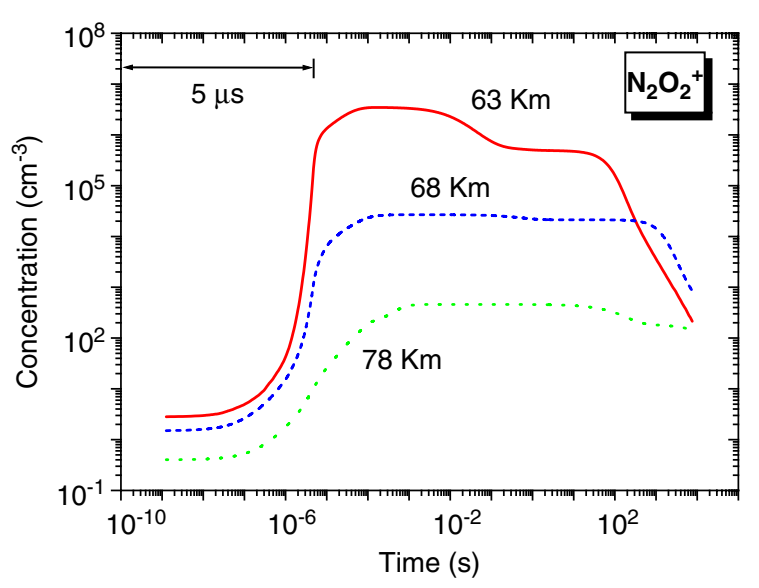

Figure 9. Time-dependent behaviour of the concentration of $\mathrm{N}_{2} \mathrm{O}_{2}^{+}$ ions under the conditions of a single sprite event for three different altitudes. The lines indicate the same as in figure 1.

It can be seen in figure 9 that, during the electric pulse ( $\leqslant 5 \mu \mathrm{s}$ ), the number density of $\mathrm{N}_{2} \mathrm{O}_{2}^{+}$exhibits the sharpest increase at the lowest altitude $(63 \mathrm{~km})$ and as the altitude increases its growth becomes smoother (as for $78 \mathrm{~km}$ ). An interesting feature of $\mathrm{N}_{2} \mathrm{O}_{2}^{+}$is the fact that it keeps relatively high values at $63 \mathrm{~km}\left(10^{4} \mathrm{~cm}^{-3}\right)$ and $68 \mathrm{~km}\left(10^{3} \mathrm{~cm}^{-3}\right)$ up to $500 \mathrm{~s}$ and even longer but, in any case, quite a long time after the pulse is over. Before the pulse finishes $(\leqslant 5 \mu \mathrm{s})$, the main kinetic channel that produces $\mathrm{N}_{2} \mathrm{O}_{2}^{+}$is

$$
\text { P305: } \mathrm{O}_{2}^{+}+\mathrm{N}_{2}+\mathrm{N}_{2} \rightarrow \mathrm{N}_{2} \mathrm{O}_{2}^{+}+\mathrm{N}_{2} \text {, }
$$

while, for times $\leqslant 5 \mu$ s, the main losses of $\mathrm{N}_{2} \mathrm{O}_{2}^{+}$ions are due electron dissociative recombination mechanisms:

$$
\begin{aligned}
& \text { P86 : e }+\mathrm{N}_{2} \mathrm{O}_{2}^{+} \rightarrow \mathrm{NO}+\mathrm{NO}, \\
& \text { P87 : e }+\mathrm{N}_{2} \mathrm{O}_{2}^{+} \rightarrow \mathrm{N}_{2}+\mathrm{O}_{2} .
\end{aligned}
$$

After the electric pulse ( $>5 \mu \mathrm{s}), \mathrm{N}_{2} \mathrm{O}_{2}^{+}$ions are mainly produced at $63 \mathrm{~km}$ through $\mathrm{P} 308: \mathrm{O}_{4}^{+}+\mathrm{N}_{2} \rightarrow \mathrm{N}_{2} \mathrm{O}_{2}^{+}+\mathrm{O}_{2}$, while at 68 and $78 \mathrm{~km}$, the dominant production mechanism of $\mathrm{N}_{2} \mathrm{O}_{2}^{+}$ions is still P305: $\mathrm{O}_{2}^{+}+\mathrm{N}_{2}+\mathrm{N}_{2} \rightarrow \mathrm{N}_{2} \mathrm{O}_{2}^{+}+\mathrm{N}_{2}$. However, after the pulse, the production rates become much lower in comparison with the very important loss processes P86 and P87 that now produce a decrease in the concentration of $\mathrm{N}_{2} \mathrm{O}_{2}^{+}$.

The behaviour of $\mathrm{N}_{2}^{+}$is shown in figure 10 where it is clearly seen that, as in the case of $\mathrm{N}_{2} \mathrm{O}_{2}^{+}$, the concentration of $\mathrm{N}_{2}^{+}$exhibits a sharp increase in the vicinity of the pulse end $(\sim 5 \mu \mathrm{s})$. However, a distinct feature of $\mathrm{N}_{2}^{+}$with respect to $\mathrm{N}_{2} \mathrm{O}_{2}^{+}$ions is that once $\mathrm{N}_{2}^{+}$has reached a maximum, its concentration decreases relatively fast (the lower the altitude, a quicker decline is predicted). The main production mechanisms before the pulse ends $(\leqslant 5 \mu \mathrm{s})$ are

$$
\begin{aligned}
& \text { P16: } \mathrm{N}_{2}+\mathrm{e} \rightarrow \mathrm{N}_{2}^{+}+2 \mathrm{e}, \\
& \text { P478: } \mathrm{N}_{2}^{+}\left(B^{2} \Sigma_{\mathrm{u}}^{+}\right) \rightarrow \mathrm{N}_{2}^{+}+h \nu_{3} .
\end{aligned}
$$

A less important production channel is the charge transfer process $\mathrm{P} 270: \mathrm{Ar}^{+}+\mathrm{N}_{2} \rightarrow \mathrm{Ar}+\mathrm{N}_{2}^{+}$. The disappearance of $\mathrm{N}_{2}^{+}$is driven mainly by

$$
\begin{aligned}
& \mathrm{P} 275: \mathrm{N}_{2}^{+}+\mathrm{O}_{2} \rightarrow \mathrm{N}_{2}+\mathrm{O}_{2}^{+}, \\
& \text {P280: } \mathrm{N}_{2}^{+}+\mathrm{N}_{2}+\mathrm{N}_{2} \rightarrow \mathrm{N}_{4}^{+}+\mathrm{N}_{2} .
\end{aligned}
$$

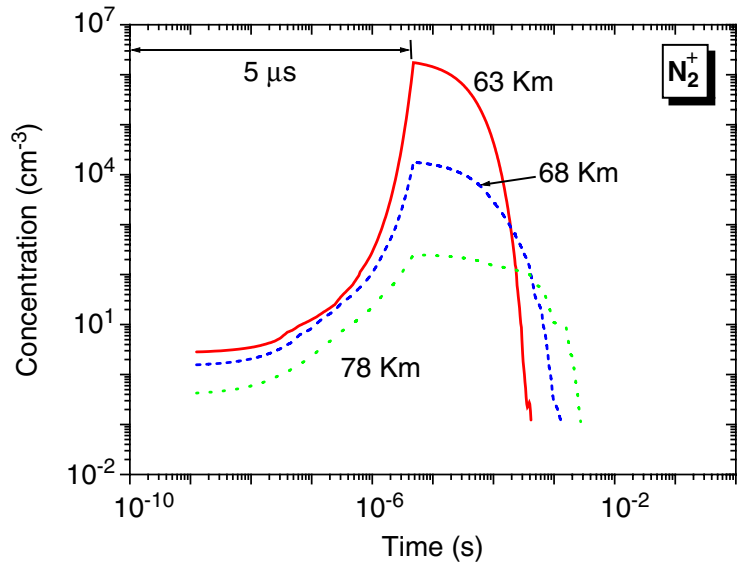

Figure 10. Time-dependent behaviour of the concentration of $\mathrm{N}_{2}^{+}$ ions under the conditions of a single sprite event for three different altitudes. The lines indicate the same as in figure 1.

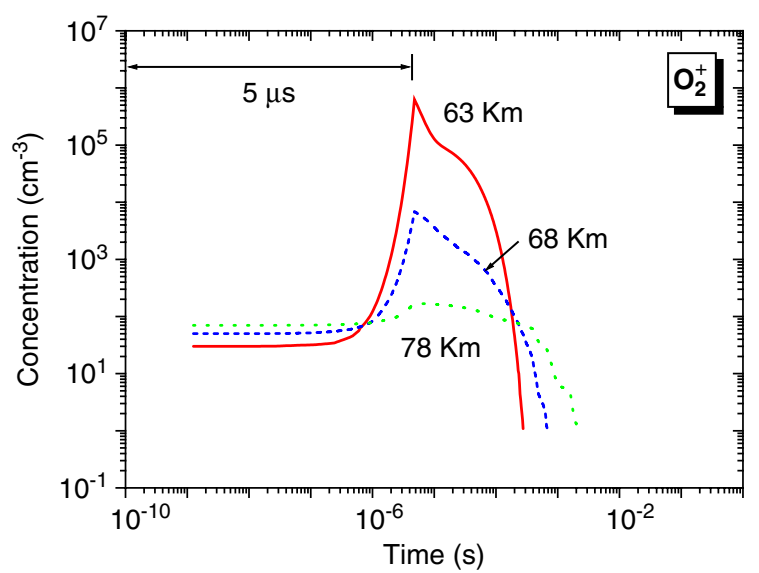

Figure 11. Time-dependent behaviour of the concentration of $\mathrm{O}_{2}^{+}$ ions under the conditions of a single sprite event for three different altitudes. The lines indicate the same as in figure 1.

When the pulse is over ( $>5 \mu \mathrm{s}$ ), P270: $\mathrm{Ar}^{+}+\mathrm{N}_{2} \rightarrow \mathrm{Ar}+\mathrm{N}_{2}^{+}$ becomes the major production channel of $\mathrm{N}_{2}^{+}$at 63,68 and $78 \mathrm{~km}$ but closely followed by P478: $\mathrm{N}_{2}^{+}\left(B^{2} \Sigma_{\mathrm{u}}^{+}\right) \rightarrow \mathrm{N}_{2}^{+}+h \nu_{3}$ at $68 \mathrm{~km}$, while the second channel (much less important than P270) at 63 and $78 \mathrm{~km}$ is P181: $\mathrm{N}_{2}\left(a^{1} \Pi_{\mathrm{g}}\right)+\mathrm{N}_{2}\left(a^{1} \Pi_{\mathrm{g}}\right) \rightarrow$ $\mathrm{N}_{2}+\mathrm{N}_{2}^{+}+\mathrm{e}$. The losses of $\mathrm{N}_{2}^{+}$after the pulse remain controlled by $\mathrm{P} 275$ and $\mathrm{P} 280$.

The trend shown in figure 11 corresponds to the concentration of $\mathrm{O}_{2}^{+}$during and after the electric pulse. Its behaviour and values are quite similar to those exhibited by $\mathrm{N}_{2}^{+}$described above. Before the pulse is finished $(<5 \mu \mathrm{s})$, the reactions that contribute most to the production of $\mathrm{O}_{2}^{+}$are (in order of importance)

$$
\begin{aligned}
& \mathrm{P} 21: \mathrm{O}_{2}+\mathrm{e} \rightarrow \mathrm{O}_{2}^{+}+2 \mathrm{e}, \\
& \text { P275: } \mathrm{N}_{2}^{+}+\mathrm{O}_{2} \rightarrow \mathrm{N}_{2}+\mathrm{O}_{2}^{+}, \\
& \text {P271: } \mathrm{Ar}^{+}+\mathrm{O}_{2} \rightarrow \mathrm{Ar}+\mathrm{O}_{2}^{+}, \\
& \text {P291: } \mathrm{O}^{+}+\mathrm{O}_{2} \rightarrow \mathrm{O}_{2}^{+}+\mathrm{O} .
\end{aligned}
$$

The main $\mathrm{O}_{2}^{+}$losses at $63 \mathrm{~km}$ are due to

$$
\begin{aligned}
& \text { P305: } \mathrm{O}_{2}^{+}+\mathrm{N}_{2}+\mathrm{N}_{2} \rightarrow \mathrm{N}_{2} \mathrm{O}_{2}^{+}+\mathrm{N}_{2}, \\
& \text { P70 : e }+\mathrm{O}_{2}^{+} \rightarrow \mathrm{O}+\mathrm{O}\left({ }^{1} \mathrm{D}\right),
\end{aligned}
$$




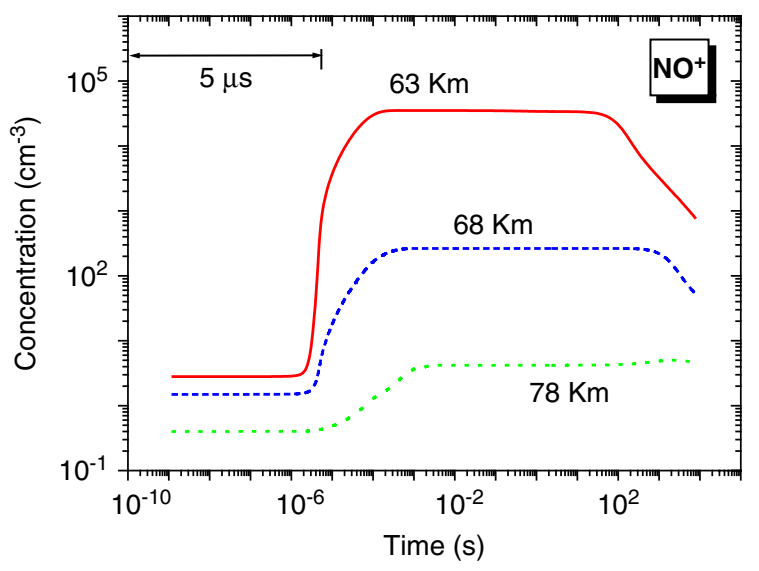

Figure 12. Time-dependent behaviour of the concentration of $\mathrm{NO}^{+}$ ions under the conditions of a single sprite event for three different altitudes. The lines indicate the same as in figure 1 .

while at 68 and $78 \mathrm{~km}$ the reaction $\mathrm{P} 70$ is replaced by $\mathrm{P} 304$ : $\mathrm{O}_{2}^{+}+\mathrm{O}_{2}+\mathrm{O}_{2} \rightarrow \mathrm{O}_{4}^{+}+\mathrm{O}_{2}$. When the pulse is finished $(>5 \mu \mathrm{s})$, the production of $\mathrm{O}_{2}^{+}$at 63 and $68 \mathrm{~km}$ is controlled by

$$
\begin{aligned}
& \mathrm{P} 275: \mathrm{N}_{2}^{+}+\mathrm{O}_{2} \rightarrow \mathrm{N}_{2}+\mathrm{O}_{2}^{+}, \\
& \text {P288: } \mathrm{N}_{4}^{+}+\mathrm{O}_{2} \rightarrow \mathrm{O}_{2}^{+}+\mathrm{N}_{2}+\mathrm{N}_{2},
\end{aligned}
$$

while at $78 \mathrm{~km}$ the process $\mathrm{P} 288$ is replaced by $\mathrm{P} 291: \mathrm{O}^{+}+$ $\mathrm{O}_{2} \rightarrow \mathrm{O}_{2}^{+}+\mathrm{O}$. The $\mathrm{O}_{2}^{+}$removal after the pulse is driven by the same mechanisms that control it during the pulse.

The plots shown in figure 12 are related to the timedependent solution of $\mathrm{NO}^{+}$for the three altitudes considered. The maximum values reached by the concentration of $\mathrm{NO}^{+}$are smaller than those of $\mathrm{N}_{2} \mathrm{O}_{2}^{+}, \mathrm{N}_{2}^{+}$and $\mathrm{O}_{2}^{+}$. Its highest value is always exhibited for the three altitudes considered right after the end of the pulse. The sudden rise in the $\mathrm{NO}^{+}$density at the end of the pulse $(<5 \mu \mathrm{s})$ is mainly due to the action of

$$
\mathrm{P} 290: \mathrm{O}^{+}+\mathrm{N}_{2} \rightarrow \mathrm{NO}^{+}+\mathrm{N} \text {, }
$$

followed by less important mechanisms such as $\mathrm{P} 300: \mathrm{O}_{2}^{+}+$ $\mathrm{N}_{2} \rightarrow \mathrm{NO}^{+}+\mathrm{NO}$ at $63 \mathrm{~km}, \mathrm{P} 34: \mathrm{NO}+\mathrm{e} \rightarrow \mathrm{NO}^{+}+2 \mathrm{e}$ at $68 \mathrm{~km}$ and P274: $\mathrm{N}_{2}^{+}+\mathrm{O} \rightarrow \mathrm{NO}^{+}+\mathrm{N}$ at $78 \mathrm{~km}$. When the electric pulse is over $(>5 \mu \mathrm{s})$, the production channels of $\mathrm{NO}^{+}$ at $63 \mathrm{~km}$ (up to $t \sim 0.1 \mathrm{~ms}$ ) are

$$
\begin{aligned}
& \mathrm{P} 290: \mathrm{O}^{+}+\mathrm{N}_{2} \rightarrow \mathrm{NO}^{+}+\mathrm{N}, \\
& \text { P274 : } \mathrm{N}_{2}^{+}+\mathrm{O} \rightarrow \mathrm{NO}^{+}+\mathrm{N}, \\
& \text { P300: } \mathrm{O}_{2}^{+}+\mathrm{N}_{2} \rightarrow \mathrm{NO}^{+}+\mathrm{NO},
\end{aligned}
$$

while at $68 \mathrm{~km} \mathrm{P} 300$ replaces P274 after P290 and, at $78 \mathrm{~km}$, $\mathrm{P} 290: \mathrm{O}^{+}+\mathrm{N}_{2} \rightarrow \mathrm{NO}^{+}+\mathrm{N}$ is the most important reactions producing $\mathrm{NO}^{+}$. However, for times $>5 \mu \mathrm{s}$, all the latter mechanisms (P274, P300 and P290) are very soon superseded by a number of loss channels that become dominant as

$$
\begin{aligned}
& \mathrm{P} 72: \mathrm{e}+\mathrm{NO}^{+} \rightarrow \mathrm{N}+\mathrm{O}, \\
& \mathrm{P} 73: \mathrm{e}+\mathrm{NO}^{+} \rightarrow \mathrm{N}\left({ }^{2} \mathrm{D}\right)+\mathrm{O} .
\end{aligned}
$$

Finally, we see in figure 13 how the concentration of $\mathrm{Ar}^{+}$ ions changes with the altitude before and after the electric pulse. This ion is produced by electron-impact ionization of $\mathrm{Ar}$ atoms $\mathrm{P} 2: \mathrm{Ar}+\mathrm{e} \rightarrow \mathrm{Ar}^{+}+2 \mathrm{e}$, while the disappearance of $\mathrm{Ar}^{+}$ is due to the combined effect of the charge transfer mechanisms $\mathrm{P} 270: \mathrm{Ar}^{+}+\mathrm{N}_{2} \rightarrow \mathrm{Ar}+\mathrm{N}_{2}^{+}$and P271: $\mathrm{Ar}^{+}+\mathrm{O}_{2} \rightarrow \mathrm{Ar}+\mathrm{O}_{2}^{+}$.

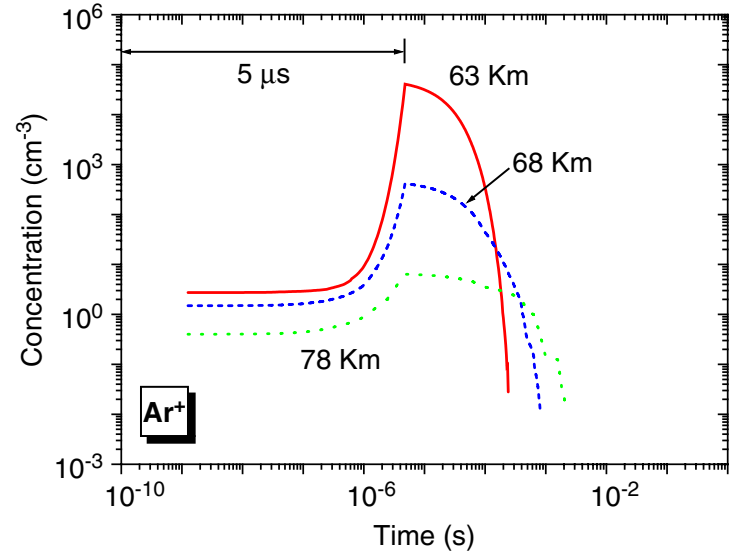

Figure 13. Time-dependent behaviour of the concentration of $\mathrm{Ar}^{+}$ ions under the conditions of a single sprite event for three different altitudes. The lines indicate the same as in figure 1 .

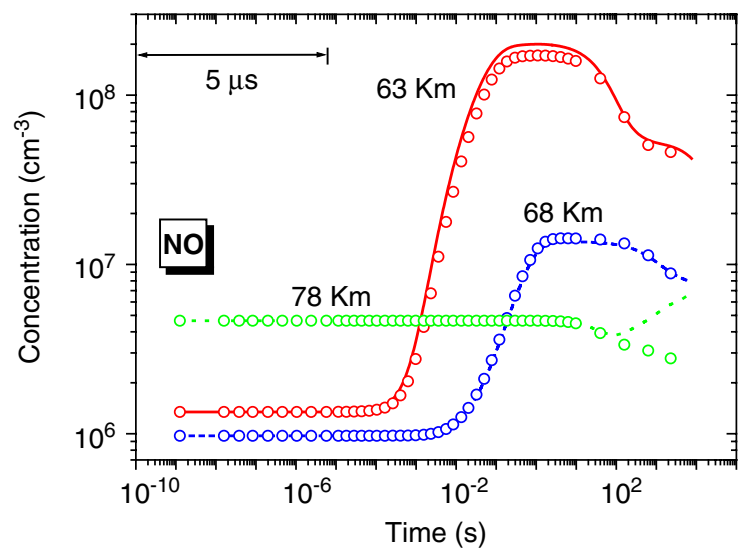

Figure 14. Time-dependent behaviour of the concentration of NO under the conditions of a single sprite event for three different altitudes. The lines indicate the same as in figure 1 (with $4 \mathrm{ppm}$ of $\mathrm{H}_{2} \mathrm{O}$ ) and the open circles stand for the case of dry air plasmas.

\subsection{Ground and excited neutrals}

In this section we discuss the values and trends exhibited by a number of ground and excited neutrals. We will start by analysing the behaviour of the nitride oxides $\mathrm{NO}, \mathrm{NO}_{2}$ and $\mathrm{NO}_{3}$.

The trends of $\mathrm{NO}$ at the different altitudes studied are shown in figure 14. While $\mathrm{NO}$ at 63 and $68 \mathrm{~km}$ exhibits a growth in the time domain after the pulse, at $78 \mathrm{~km}$ its concentration remains constant or exhibits a slight increase or decrease, both less than a factor of 2 , depending on whether humid air (dotted line) or dry air (open circles) is studied. We have considered 64 production mechanisms and 44 removal channels of NO. Right before the end of the electric pulse $(<5 \mu \mathrm{s})$, the main reactions (in order of importance) contributing to the formation of $\mathrm{NO}$ at $63 \mathrm{~km}$ are

$$
\begin{aligned}
& \text { P172: } \left.\mathrm{N}^{2} \mathrm{D}\right)+\mathrm{O}_{2} \rightarrow \mathrm{NO}+\mathrm{O}, \\
& \text { P86 }: \mathrm{e}+\mathrm{N}_{2} \mathrm{O}_{2}^{+} \rightarrow \mathrm{NO}+\mathrm{NO}, \\
& \text { P91 }: \mathrm{N}+\mathrm{O}_{2} \rightarrow \mathrm{NO}+\mathrm{O}, \\
& \text { P244 }: \mathrm{N}_{2} \mathrm{O}_{2}^{+}+\mathrm{O}^{-} \rightarrow \mathrm{NO}+\mathrm{NO}+\mathrm{O},
\end{aligned}
$$

while at $68 \mathrm{~km}$, the third process $\mathrm{P} 91$ is replaced by $\mathrm{P} 350$ : $\mathrm{NO}^{-}+\mathrm{O}_{2} \rightarrow \mathrm{O}_{2}^{-}+\mathrm{NO}$, and $\mathrm{P} 91$ becomes the fourth. At $78 \mathrm{~km}$, 
the dominant reaction is $\mathrm{P} 172$ followed by $\mathrm{P} 350$. The principal losses of NO before the end of the electric pulse $(<5 \mu \mathrm{s})$ at $63 \mathrm{~km}$ are due to

$$
\begin{aligned}
& \mathrm{P} 113: \mathrm{O}+\mathrm{NO} \rightarrow \mathrm{NO}_{2}, \\
& \text { P239: } \mathrm{N}_{2}\left(A^{3} \Sigma_{\mathrm{u}}^{+}\right)+\mathrm{NO} \rightarrow \mathrm{NO}\left(A^{2} \Sigma^{+}\right)+\mathrm{N}_{2}, \\
& \text { P184: } \mathrm{N}_{2}\left(a^{1} \Pi_{\mathrm{g}}\right)+\mathrm{NO} \rightarrow \mathrm{N}_{2}+\mathrm{N}+\mathrm{O}, \\
& \text { P115: } \mathrm{N}+\mathrm{NO} \rightarrow \mathrm{N}_{2}+\mathrm{O},
\end{aligned}
$$

while, at $68 \mathrm{~km}, \mathrm{P} 239$ is replaced by $\mathrm{P} 411: \mathrm{HO}_{2}+\mathrm{NO} \rightarrow$ $\mathrm{OH}+\mathrm{NO}_{2}$. However, at $78 \mathrm{~km}, \mathrm{P} 113: \mathrm{O}+\mathrm{NO} \rightarrow \mathrm{NO}_{2}$, $\mathrm{P} 411: \mathrm{HO}_{2}+\mathrm{NO} \rightarrow \mathrm{OH}+\mathrm{NO}_{2}$ and $\mathrm{P} 414: \mathrm{HO}_{2}+\mathrm{NO} \rightarrow$ $\mathrm{O}_{2}+\mathrm{HNO}$ become the first, second and third main loss channels, respectively. At time $\sim 0.01 \mathrm{~s}$, the first and second gain channels of NO at 63 and $68 \mathrm{~km}$ are the same as before the end of the pulse. The loss of NO at about $0.01 \mathrm{~s}$ at all the altitudes studied is mainly due to processes P113 and $\mathrm{P} 115: \mathrm{N}+\mathrm{NO} \rightarrow \mathrm{N}_{2}+\mathrm{O}$ and $\mathrm{P} 411$ (at $78 \mathrm{~km}$ ). At time $\sim 100 \mathrm{~s}$, the production of $\mathrm{NO}$ at $63 \mathrm{~km}$ is due to

$$
\begin{aligned}
& \text { P91 : N }+\mathrm{O}_{2} \rightarrow \mathrm{NO}+\mathrm{O}, \\
& \text { P109: } \mathrm{O}+\mathrm{NO}_{2} \rightarrow \mathrm{O}_{2}+\mathrm{NO}, \\
& \text { P172: }\left({ }^{2} \mathrm{D}\right)+\mathrm{O}_{2} \rightarrow \mathrm{NO}+\mathrm{O} .
\end{aligned}
$$

However, at $68 \mathrm{~km}, \mathrm{P} 172$ becomes the second most important process after $\mathrm{P} 91$, and $\mathrm{P} 417: \mathrm{HO}_{2}+\mathrm{N} \rightarrow \mathrm{OH}+\mathrm{NO}$ becomes the third. At $78 \mathrm{~km}, \mathrm{P} 172$ replaces $\mathrm{P} 91, \mathrm{P} 109$ remains the second and $\mathrm{P} 373: \mathrm{H}+\mathrm{NO}_{2} \rightarrow \mathrm{NO}+\mathrm{OH}$ becomes the third most important production reaction of NO. The latter explains why, at $78 \mathrm{~km}$ from approximately $t \sim 200 \mathrm{~s}$, a slight difference is exhibited between the higher NO density predicted in humid air (where P373 is active) and the slightly lower NO concentration in dry air (where P373 is not present). The loss of NO at about $100 \mathrm{~s}$ at all the altitudes studied is mainly due to processes P113 and P115: N $+\mathrm{NO} \rightarrow \mathrm{N}_{2}+\mathrm{O}$.

One of the most remarkable features visible in figure 14 is the fact that NO increases by two orders of magnitude at $63 \mathrm{~km}$, one order of magnitude at $68 \mathrm{~km}$ and, at $78 \mathrm{~km}$, our model predicts an almost constant concentration of NO after the passage of a single sprite. Therefore, it seems that, according to the present model, the impact of the chemical activity associated with a single sprite event in NO is relatively important at 63 and $68 \mathrm{~km}$.

The time-dependent behaviour of the concentration of nitrogen dioxide $\left(\mathrm{NO}_{2}\right)$ is presented in figure 15 . It can be seen that $\mathrm{NO}_{2}$ remains constant up to $\sim 0.01 \mathrm{~s}$ (at 78 and $63 \mathrm{~km}$ ) and $\sim 100 \mathrm{~s}$ (at $68 \mathrm{~km}$ ) where it exhibits a sharp increase at $78 \mathrm{~km}$ of about three orders of magnitude and smoother growths at $63 \mathrm{~km}$ (about two orders of magnitude) and $68 \mathrm{~km}$ (one order of magnitude), respectively. In order to trace the roots of this behaviour, we have considered 34 different source terms for $\mathrm{NO}_{2}$ and 40 removal channels. At time $\sim 0.01 \mathrm{~s}$, the production of $\mathrm{NO}_{2}$ at $63 \mathrm{~km}$ is controlled by

$$
\begin{aligned}
& \mathrm{P} 113: \mathrm{O}+\mathrm{NO} \rightarrow \mathrm{NO}_{2}, \\
& \text { P337: } \mathrm{O}_{2}^{-}+\mathrm{N} \rightarrow \mathrm{NO}_{2}+\mathrm{e}, \\
& \mathrm{P} 116: \mathrm{O}_{3}+\mathrm{NO} \rightarrow \mathrm{O}_{2}+\mathrm{NO}_{2} .
\end{aligned}
$$

But at 68 and $78 \mathrm{~km}, \mathrm{P} 337$ is replaced by $\mathrm{P} 411: \mathrm{HO}_{2}+\mathrm{NO} \rightarrow$ $\mathrm{OH}+\mathrm{NO}_{2}$. The main $\mathrm{NO}_{2}$ losses at $\sim 0.01 \mathrm{~s}$ and $63 \mathrm{~km}$ are

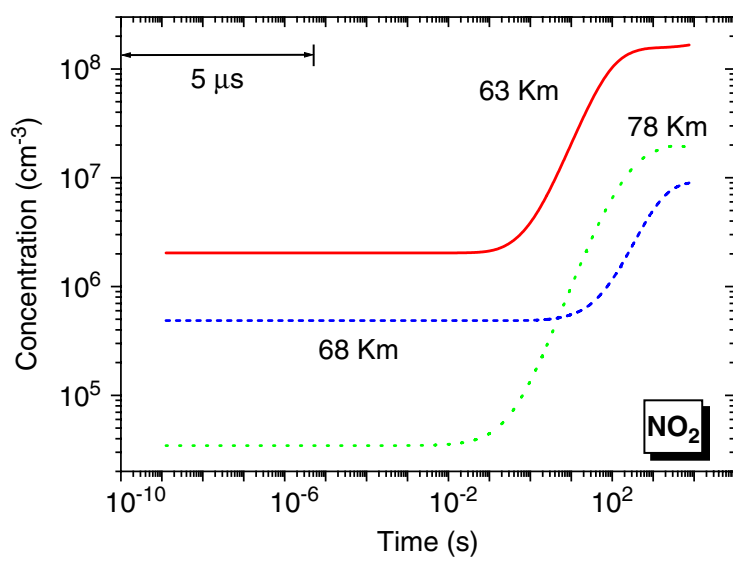

Figure 15. Time-dependent behaviour of the concentration of $\mathrm{NO}_{2}$ under the conditions of a single sprite event for three different altitudes. The lines indicate the same as in figure 1.

associated with

$$
\begin{aligned}
& \mathrm{P} 109: \mathrm{O}+\mathrm{NO}_{2} \rightarrow \mathrm{O}_{2}+\mathrm{NO}, \\
& \text { P93 }: \mathrm{N}+\mathrm{NO}_{2} \rightarrow \mathrm{O}+\mathrm{N}_{2} \mathrm{O}, \\
& \text { P95 }: \mathrm{N}+\mathrm{NO}_{2} \rightarrow \mathrm{NO}+\mathrm{NO} .
\end{aligned}
$$

While at $68 \mathrm{~km}, \mathrm{P} 95$ is replaced by $\mathrm{P} 62: \mathrm{e}+\mathrm{NO}_{2} \rightarrow \mathrm{NO}_{2}^{-}$. At time $\sim 100 \mathrm{~s}$, the dominant source term of $\mathrm{NO}_{2}$ is $\mathrm{P} 113$ for the three altitudes considered and followed in importance by $\mathrm{P} 116\left(\right.$ at $63 \mathrm{~km}$ ) and $\mathrm{P} 411: \mathrm{HO}_{2}+\mathrm{NO} \rightarrow \mathrm{OH}+\mathrm{NO}_{2}$ (for 68 and $78 \mathrm{~km}$ ). The losses of $\mathrm{NO}_{2}$ at $\sim 100 \mathrm{~s}$ are the same as those described for time $\sim 0.01 \mathrm{~s}$.

We can see in figure 16 that $\mathrm{NO}_{3}$ exhibits a flat shape up to $\sim 100 \mathrm{~s}$ (for 63 and $68 \mathrm{~km}$ ) and $10 \mathrm{~s}$ (for $78 \mathrm{~km}$ ) where it starts to increase. The growth of $\mathrm{NO}_{3}$ is of about two orders of magnitude at 78 and $68 \mathrm{~km}$ and a factor of 30 for $63 \mathrm{~km}$. The reactions underlying the increase in $\mathrm{NO}_{3}$ at 63 and $68 \mathrm{~km}$ are

$$
\begin{aligned}
& \mathrm{P} 253: \mathrm{N}_{2} \mathrm{O}_{2}^{+}+\mathrm{NO}_{3}^{-} \rightarrow \mathrm{NO}_{3}+\mathrm{N}_{2}+\mathrm{O}_{2}, \\
& \text { P252: } \mathrm{N}_{2} \mathrm{O}_{2}^{+}+\mathrm{NO}_{3}^{-} \rightarrow \mathrm{NO}+\mathrm{NO}+\mathrm{NO}_{3}, \\
& \text { P104: } \mathrm{NO}_{2}+\mathrm{O}_{3} \rightarrow \mathrm{NO}_{3}+\mathrm{O}_{2},
\end{aligned}
$$

while at $78 \mathrm{~km}$, the production of $\mathrm{NO}_{3}$ is due to

$$
\begin{aligned}
& \mathrm{P} 105: \mathrm{O}+\mathrm{NO}_{2}+\mathrm{N}_{2} \rightarrow \mathrm{NO}_{3}+\mathrm{N}_{2}, \\
& \text { P106: } \mathrm{O}+\mathrm{NO}_{2}+\mathrm{O}_{2} \rightarrow \mathrm{NO}_{3}+\mathrm{O}_{2} .
\end{aligned}
$$

The losses are negligible and only P107: $\mathrm{O}+\mathrm{NO}_{3} \rightarrow \mathrm{NO}_{2}+\mathrm{O}_{2}$ is of marginal importance.

The behaviour of $\mathrm{O}\left({ }^{3} \mathrm{P}\right)$ is shown in figure 17 where it can be seen that, depending on the altitude, the concentration of $\mathrm{O}\left({ }^{3} \mathrm{P}\right)$ sharply increases by more than seven orders of magnitude in less than $5 \mu \mathrm{s}$ (at $63 \mathrm{~km}$ ), it exhibits a moderate growth at $68 \mathrm{~km}$ in two successive steps before $5 \mu \mathrm{s}$ and between $5 \mu \mathrm{s}$ and $1 \mathrm{~s}$ and, at $78 \mathrm{~km}, \mathrm{O}\left({ }^{3} \mathrm{P}\right)$ remains constant up to $1000 \mathrm{~s}$ where it starts to decrease slightly. We have considered 99 source terms for $\mathrm{O}\left({ }^{3} \mathrm{P}\right)$ and 46 loss mechanisms. The main reactions contributing to the production of $\mathrm{O}\left({ }^{3} \mathrm{P}\right)$ before the end of the pulse $(<5 \mu \mathrm{s})$ at all the altitudes investigated are

$$
\begin{aligned}
& \text { P24: } \mathrm{O}_{2}+\mathrm{e} \rightarrow \mathrm{O}+\mathrm{O}+\mathrm{e}, \\
& \text { P52 }: \mathrm{e}+\mathrm{O}_{2} \rightarrow \mathrm{O}+\mathrm{O}\left({ }^{1} \mathrm{D}\right)+\mathrm{e}, \\
& \text { P194: } \mathrm{N}_{2}\left(B^{3} \Pi_{\mathrm{g}}\right)+\mathrm{O}_{2} \rightarrow \mathrm{N}_{2}+\mathrm{O}+\mathrm{O}, \\
& \text { P204: } \mathrm{O}\left({ }^{1} \mathrm{D}\right)+\mathrm{N}_{2} \rightarrow \mathrm{O}+\mathrm{N}_{2} .
\end{aligned}
$$




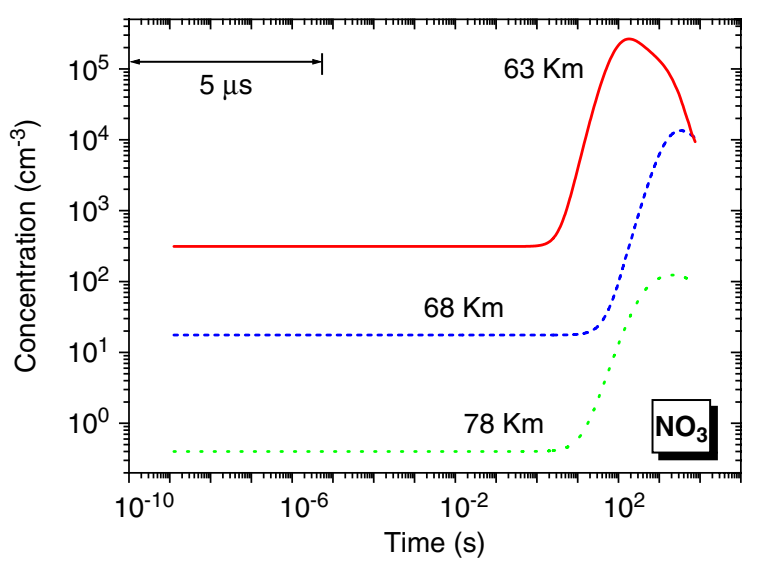

Figure 16. Time-dependent behaviour of the concentration of $\mathrm{NO}_{3}$ under the conditions of a single sprite event for three different altitudes. The lines indicate the same as in figure 1.

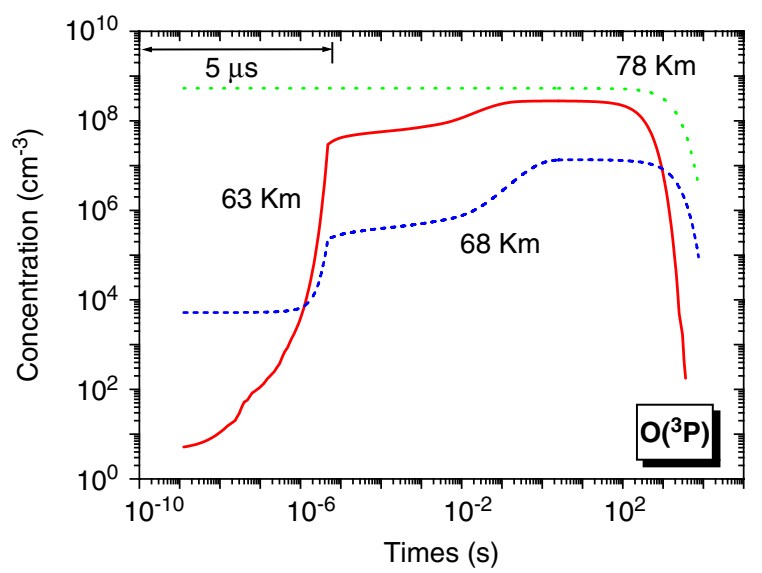

Figure 17. Time-dependent behaviour of the concentration of $\mathrm{O}\left({ }^{3} \mathrm{P}\right)$ under the conditions of a single sprite event for three different altitudes. The lines indicate the same as in figure 1.

While the losses at $63 \mathrm{~km}$ are controlled by

$$
\begin{aligned}
& \mathrm{P} 29: \mathrm{O}+\mathrm{e} \rightarrow \mathrm{O}\left({ }^{1} \mathrm{D}\right)+\mathrm{e}, \\
& \text { P122: } \mathrm{O}+\mathrm{O}_{2}+\mathrm{N}_{2} \rightarrow \mathrm{O}_{3}+\mathrm{N}_{2}, \\
& \text { P28: } \mathrm{O}+\mathrm{e} \rightarrow \mathrm{O}^{+}+2 \mathrm{e}, \\
& \text { P121: } \mathrm{O}+\mathrm{O}_{2}+\mathrm{O}_{2} \rightarrow \mathrm{O}_{3}+\mathrm{O}_{2},
\end{aligned}
$$

But, at $68 \mathrm{~km}, \mathrm{P} 122$ becomes the dominant removal process followed by $\mathrm{P} 121$ and $\mathrm{P} 410: \mathrm{HO}_{2}+\mathrm{O} \rightarrow \mathrm{OH}+\mathrm{O}_{2}$. However, at $78 \mathrm{~km}, \mathrm{P} 113: \mathrm{O}+\mathrm{NO} \rightarrow \mathrm{NO}_{2}$ is the dominant loss followed by $\mathrm{P} 410$. At time $\sim 0.01 \mathrm{~s}$, the production of $\mathrm{O}\left({ }^{3} \mathrm{P}\right)$ at $63 \mathrm{~km}$ is due to

$$
\begin{aligned}
& \mathrm{P} 172: \mathrm{N}\left({ }^{2} \mathrm{D}\right)+\mathrm{O}_{2} \rightarrow \mathrm{NO}+\mathrm{O}, \\
& \text { P50 : e }+\mathrm{O}_{3} \rightarrow \mathrm{O}_{2}+\mathrm{O}+\mathrm{e}, \\
& \text { P219: }\left(^{1} \mathrm{~S}\right)+\mathrm{O}_{2} \rightarrow \mathrm{O}_{2}+\mathrm{O}, \\
& \text { P237 } \mathrm{O}_{2}\left(b^{1} \Sigma_{\mathrm{g}}^{+}\right)+\mathrm{O}_{3} \rightarrow 2 \mathrm{O}_{2}\left(a^{1} \Delta_{\mathrm{g}}\right)+\mathrm{O},
\end{aligned}
$$

while, at $68 \mathrm{~km}, \mathrm{P} 219$ is replaced by $\mathrm{P} 197: \mathrm{N}_{2}\left(A^{3} \Sigma_{\mathrm{u}}^{+}\right)+\mathrm{O}_{2} \rightarrow$ $\mathrm{N}_{2} \mathrm{O}+\mathrm{O}$ and, at $78 \mathrm{~km}, \mathrm{P} 50$ and $\mathrm{P} 219$ are substituted by P196: $\mathrm{N}_{2}\left(A^{3} \Sigma_{\mathrm{u}}^{+}\right)+\mathrm{O}_{2} \rightarrow \mathrm{N}_{2}+2 \mathrm{O}$ and P197, respectively. The main $\mathrm{O}\left({ }^{3} \mathrm{P}\right)$ loss channels at about $0.01 \mathrm{~s}$ at 63 and $68 \mathrm{~km}$ are $\mathrm{P} 122$ followed by $\mathrm{P} 121$. At $78 \mathrm{~km}, \mathrm{P} 113$ is the main loss

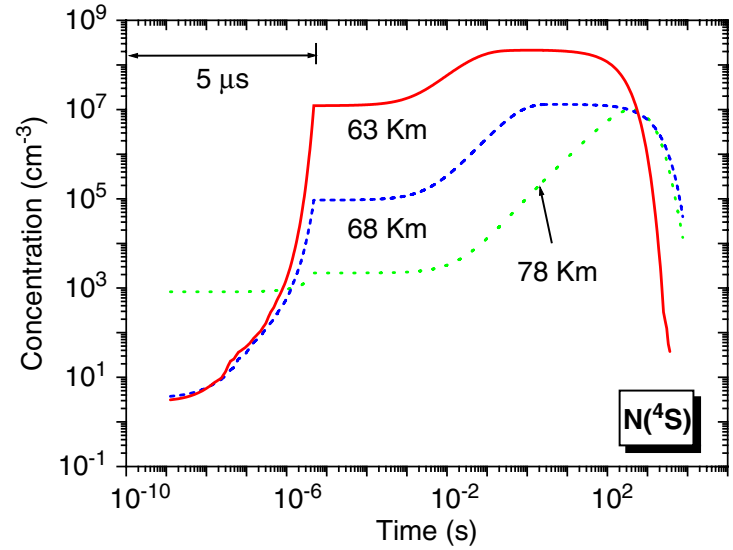

Figure 18. Time-dependent behaviour of the concentration of $\mathrm{N}$ $\left({ }^{4} \mathrm{~S}\right)$ under the conditions of a single sprite event for three different altitudes. The lines indicate the same as in figure 1.

reaction followed by $\mathrm{P} 410$. Finally, at time $\sim 500 \mathrm{~s}, \mathrm{O}\left({ }^{3} \mathrm{P}\right)$ is mainly produced at 63 and $68 \mathrm{~km}$ by

$$
\begin{aligned}
& \text { P91 }: \mathrm{N}+\mathrm{O}_{2} \rightarrow \mathrm{NO}+\mathrm{O}, \\
& \text { P115: N }+\mathrm{NO} \rightarrow \mathrm{N}_{2}+\mathrm{O}, \\
& \text { P93 }: \mathrm{N}+\mathrm{NO}_{2} \rightarrow \mathrm{O}+\mathrm{N}_{2} \mathrm{O},
\end{aligned}
$$

but, at $78 \mathrm{~km}$, the above reactions are replaced by $\mathrm{P} 375$ : $\mathrm{H}+\mathrm{O}_{3} \rightarrow \mathrm{HO}_{2}+\mathrm{O}, \mathrm{P} 172: \mathrm{N}\left({ }^{2} \mathrm{D}\right)+\mathrm{O}_{2} \rightarrow \mathrm{NO}+\mathrm{O}$ and $\mathrm{P} 387: \mathrm{OH}+\mathrm{OH} \rightarrow \mathrm{H}_{2} \mathrm{O}+\mathrm{O}$. The losses of $\mathrm{O}\left({ }^{3} \mathrm{P}\right)$ at time $\sim 500 \mathrm{~s}$ and 63 and $68 \mathrm{~km}$ are dominated by $\mathrm{P} 122$ : $\mathrm{O}+\mathrm{O}_{2}+\mathrm{N}_{2} \rightarrow \mathrm{O}_{3}+\mathrm{N}_{2}$ followed by P113: $\mathrm{O}+\mathrm{NO} \rightarrow \mathrm{NO}_{2}$ (at $63 \mathrm{~km}$ ) and $\mathrm{P} 121: \mathrm{O}+\mathrm{O}_{2}+\mathrm{O}_{2} \rightarrow \mathrm{O}_{3}+\mathrm{O}_{2}$ (at $68 \mathrm{~km}$ ). In the case of $78 \mathrm{~km}$, the losses of $\mathrm{O}\left({ }^{3} \mathrm{P}\right)$ are first due to $\mathrm{P} 388: \mathrm{OH}+\mathrm{O} \rightarrow \mathrm{O}_{2}+\mathrm{H}$ followed by $\mathrm{P} 410$.

An interesting feature of the behaviour of $\mathrm{O}\left({ }^{3} \mathrm{P}\right)$ is that, at 63 and $68 \mathrm{~km}$, the impact of a single sprite event produces a significant increase in its background value that is kept constant for a long time up to about $500 \mathrm{~s}$ and then decreases. At $78 \mathrm{~km}$, the impact of the single sprite on the $\mathrm{O}\left({ }^{3} \mathrm{P}\right)$ concentration is almost negligible.

The concentration of ground nitrogen atoms $\mathrm{N}\left({ }^{4} \mathrm{~S}\right)$ is shown in figure 18 , where it can be clearly seen that as the altitude decreases (from 78 to $63 \mathrm{~km}$ ) the $\mathrm{N}\left({ }^{4} \mathrm{~S}\right)$ growth becomes sharper before the end of the electric pulse $(<5 \mu \mathrm{s})$. After the pulse, there is a second growth stage at 68 and $78 \mathrm{~km}$ while $\mathrm{N}\left({ }^{4} \mathrm{~S}\right)$ remains constant up to about $100 \mathrm{~s}$ when it goes down very fast. We have considered 38 source terms for $\mathrm{N}\left({ }^{4} \mathrm{~S}\right)$ and 20 loss mechanisms. Before the pulse is over $(<5 \mu \mathrm{s})$, the main production of $\mathrm{N}\left({ }^{4} \mathrm{~S}\right)$ is electron-impact dissociation and electron-driven dissociative excitation:

$$
\begin{aligned}
& \text { P18 }: \mathrm{N}_{2}+\mathrm{e} \rightarrow \mathrm{N}+\mathrm{N}+\mathrm{e}, \\
& \text { P19 }: \mathrm{N}_{2}+\mathrm{e} \rightarrow \mathrm{N}+\mathrm{N}\left({ }^{2} \mathrm{D}\right)+\mathrm{e}, \\
& \text { P20 }: \mathrm{N}_{2}+\mathrm{e} \rightarrow \mathrm{N}+\mathrm{N}\left({ }^{2} \mathrm{P}\right)+\mathrm{e},
\end{aligned}
$$

and the losses of $\mathrm{N}\left({ }^{4} \mathrm{~S}\right)$ at 63 and $68 \mathrm{~km}$ are controlled by

$$
\mathrm{P} 91: \mathrm{N}+\mathrm{O}_{2} \rightarrow \mathrm{NO}+\mathrm{O}
$$

and by $\mathrm{P} 406: \mathrm{OH}+\mathrm{N} \rightarrow \mathrm{NO}+\mathrm{H}$ at $78 \mathrm{~km}$, followed by P200: $\mathrm{N}_{2}\left(A^{3} \Sigma_{\mathrm{u}}^{+}\right)+\mathrm{N} \rightarrow \mathrm{N}_{2}+\mathrm{N}\left({ }^{2} \mathrm{P}\right)$ (at $63 \mathrm{~km}$ ) and $\mathrm{P} 115: \mathrm{N}+\mathrm{NO} \rightarrow \mathrm{N}_{2}+\mathrm{O}$ (at 68 and $78 \mathrm{~km}$ ). At time $\sim 0.01 \mathrm{~s}$, 


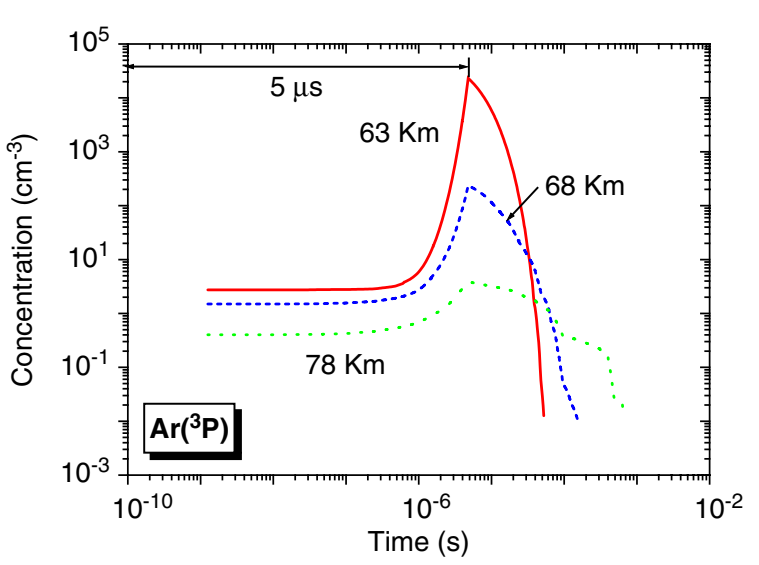

Figure 19. Time-dependent behaviour of the concentration of $\mathrm{Ar}$ $\left({ }^{3} \mathrm{P}\right)$ under the conditions of a single sprite event for three different altitudes. The lines indicate the same as in figure 1 .

the main production channel of $\mathrm{N}\left({ }^{4} \mathrm{~S}\right)$ is still the electronimpact dissociative excitation $\mathrm{P} 19$ but closely followed by the collisional de-excitation process $\mathrm{P} 174: \mathrm{N}\left({ }^{2} \mathrm{D}\right)+\mathrm{N}_{2} \rightarrow \mathrm{N}+\mathrm{N}_{2}$. The losses of $\mathrm{N}\left({ }^{4} \mathrm{~S}\right)$ around $0.01 \mathrm{~s}$ are still controlled by $\mathrm{P} 91$ for 63 and $68 \mathrm{~km}$ and by P406 for $78 \mathrm{~km}$. Finally, around $100 \mathrm{~s}$, $\mathrm{N}\left({ }^{4} \mathrm{~S}\right)$ goes down due to the same loss mechanisms acting at $0.01 \mathrm{~s}$ but that now, at $\sim 100 \mathrm{~s}$, have become dominant.

The time evolution of the concentration of ground state argon atoms $\mathrm{Ar}$ is shown in figure 19 where a sharp rise in a short time interval at 63 and $68 \mathrm{~km}$ is seen. The Ar concentration reaches its maximum value right at the end of the pulse originating the sprite. Right after the pulse, the population of Ar decreases almost as fast as it increased. Before the end of the electric pulse $(<5 \mu \mathrm{s})$, the production of Ar is controlled by collisional de-excitation and charge transfer mechanisms:

$$
\begin{aligned}
& \text { P167: } \operatorname{Ar}\left({ }^{3} \mathrm{P}_{2}\right)+\mathrm{O}_{2} \rightarrow \operatorname{Ar}+2 \mathrm{O}, \\
& \text { P165: } \operatorname{Ar}\left({ }^{3} \mathrm{P}_{2}\right)+\mathrm{N}_{2} \rightarrow \operatorname{Ar}+2 \mathrm{~N}, \\
& \text { P166: } \operatorname{Ar}\left({ }^{3} \mathrm{P}_{2}\right)+\mathrm{N}_{2} \rightarrow \operatorname{Ar}+\mathrm{N}_{2}\left(C^{3} \Pi_{\mathrm{u}}\right), \\
& \text { P270: } \mathrm{Ar}^{+}+\mathrm{N}_{2} \rightarrow \operatorname{Ar}+\mathrm{N}_{2}^{+}, \\
& \text {P271 }: \mathrm{Ar}^{+}+\mathrm{O}_{2} \rightarrow \operatorname{Ar}+\mathrm{O}_{2}^{+},
\end{aligned}
$$

and the losses are due to electron-impact ionization and excitation of argon atoms:

$$
\begin{aligned}
& \mathrm{P} 2: \mathrm{Ar}+\mathrm{e} \rightarrow \mathrm{Ar}^{+}+2 \mathrm{e}, \\
& \mathrm{P} 1: \mathrm{Ar}+\mathrm{e} \rightarrow \operatorname{Ar}\left({ }^{3} \mathrm{P}_{2}\right)+\mathrm{e} .
\end{aligned}
$$

After the pulse, the production of ground state argon atoms is driven by P271 closely followed by P270 and then (with smaller rates) P167 and P165. The losses after the pulse are now controlled by $\mathrm{P} 1$.

Among the hydrated neutrals, the hydroxyl molecule $\mathrm{OH}$ can be of primary importance since it participates in one of the catalytic cycles contributing to the removal of $\mathrm{O}_{3}$. The trend exhibited by the concentration of $\mathrm{OH}$ at different altitudes as a consequence of a single sprite event is shown in figure 20 . In order to evaluate the dominant kinetic mechanism, we have considered 33 source terms and 23 loss channels of this molecular species. We see in figure 19 that the $\mathrm{OH}$ density

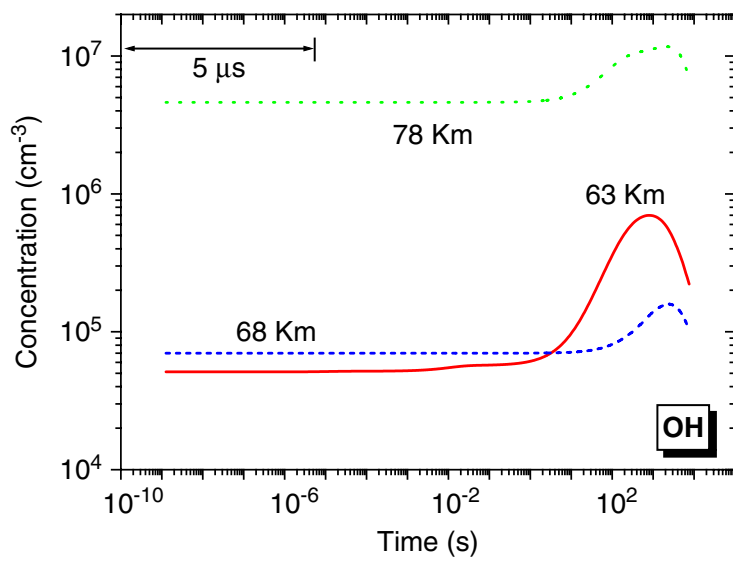

Figure 20. Time-dependent behaviour of the concentration of $\mathrm{OH}$ under the conditions of a single sprite event for three different altitudes. The lines indicate the same as in figure 1 .

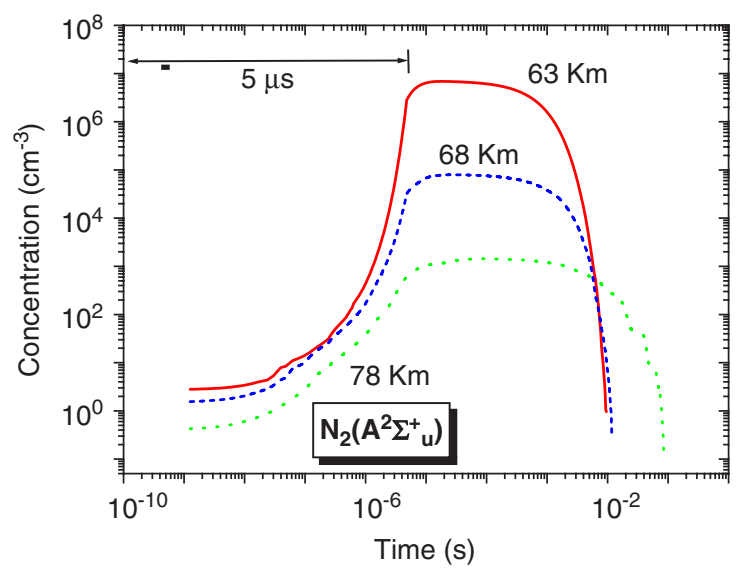

Figure 21. Time-dependent behaviour of the concentration of $\mathrm{N}_{2}\left(A^{3} \Sigma_{\mathrm{u}}^{+}\right)$under the conditions of a single sprite event for three different altitudes. The lines indicate the same as in figure 1.

remains constant up to around $10 \mathrm{~s}$ (at $78 \mathrm{~km}$ ), $\sim 100 \mathrm{~s}$ (at $68 \mathrm{~km}$ ) and $\sim 0.01 \mathrm{~s}$ (at $63 \mathrm{~km}$ ). At 63 and $68 \mathrm{~km}$, the main production mechanisms of $\mathrm{OH}$ around $0.01 \mathrm{~s}$ are

$$
\begin{aligned}
& \mathrm{P} 433: \mathrm{O}\left({ }^{1} \mathrm{~S}\right)+\mathrm{H}_{2} \mathrm{O} \rightarrow \mathrm{OH}+\mathrm{OH}, \\
& \mathrm{P} 410: \mathrm{HO}_{2}+\mathrm{O} \rightarrow \mathrm{OH}+\mathrm{O}_{2},
\end{aligned}
$$

while, at $78 \mathrm{~km}$, the first channel contributing to $\mathrm{OH}$ is $\mathrm{P} 410$ and the second is $\mathrm{P} 374: \mathrm{H}+\mathrm{O}_{3} \rightarrow \mathrm{O}_{2}+\mathrm{OH}$. The losses of $\mathrm{OH}$ at $\sim 0.01 \mathrm{~s}$ are almost negligible (when compared with the gain processes at this time); however, the leading loss channels are P388: $\mathrm{OH}+\mathrm{O} \rightarrow \mathrm{O}_{2}+\mathrm{H}$ (at 63 and $78 \mathrm{~km}$ ) and $\mathrm{P} 407: \mathrm{OH}+\mathrm{CO} \rightarrow \mathrm{H}+\mathrm{CO}_{2}$ (at $68 \mathrm{~km}$ ). Later on, at $\sim 500 \mathrm{~s}$, the dominant reactions contributing to the formation of the hydroxyl molecule $\mathrm{OH}$ at the three heights investigated are first P410 and P374 in the second place, both of which have already been mentioned before. The main losses at $\sim 500 \mathrm{~s}$ are the same as those found in earlier times $(\sim 0.01 \mathrm{~s})$ for $63 \mathrm{~km}$, $78 \mathrm{~km}$ and $68 \mathrm{~km}$, respectively.

In figures 21-25, we turn our attention to the timedependent behaviour of the concentrations of a number of important electronically and vibrationally excited neutrals. In particular, we have selected here the species $\mathrm{N}_{2}\left(A^{3} \Sigma_{\mathrm{u}}^{+}\right)$, 
$\mathrm{N}_{2}\left(a^{\prime}{ }^{1} \Sigma_{\mathrm{u}}^{-}\right), \mathrm{O}_{2}\left(a^{1} \Delta_{\mathrm{g}}\right), \mathrm{O}_{2}\left(b^{1} \Sigma_{\mathrm{g}}^{+}\right)$and the vibrationally excited $\mathrm{N}_{2}\left(X^{1} \Sigma_{\mathrm{g}}^{+}(v=1, \ldots, v=8)\right)$ shown in figure 24 . We can see in figure 21 that a visible feature in the trend followed by $\mathrm{N}_{2}\left(A^{3} \Sigma_{\mathrm{u}}^{+}\right)$is that although the difference between its initial values at 63 and $78 \mathrm{~km}$ is less than one order of magnitude, the impact of a single sprite event creates a considerable difference between them right after the pulse. This means that, after a sharp increase during the pulse duration, the concentration of $\mathrm{N}_{2}\left(A^{3} \Sigma_{\mathrm{u}}^{+}\right)$at $63 \mathrm{~km}$ is almost four orders of magnitude higher than at $78 \mathrm{~km}$. The behaviour of $\mathrm{N}_{2}\left(A^{3} \Sigma_{\mathrm{u}}^{+}\right)$at $68 \mathrm{~km}$ is in between that exhibited at 63 and $78 \mathrm{~km}$. After a relatively long plateau region that lasts up to one millisecond (for 63 and $68 \mathrm{~km}$ ) and almost $0.01 \mathrm{~s}$ for $78 \mathrm{~km}$, the number density of $\mathrm{N}_{2}\left(A^{3} \Sigma_{\mathrm{u}}^{+}\right)$goes down abruptly. So, before the end of the electric pulse $(<5 \mu \mathrm{s})$, the main pumping reactions of $\mathrm{N}_{2}\left(A^{3} \Sigma_{\mathrm{u}}^{+}\right)$at 63 and $68 \mathrm{~km}$ are electron-impact excitation closely followed by radiative and collisional de-excitation from $\mathrm{N}_{2}\left(B^{3} \Pi_{\mathrm{g}}\right)$

$$
\begin{aligned}
& \text { P11: } \mathrm{N}_{2}+\mathrm{e} \rightarrow \mathrm{N}_{2}\left(A^{3} \Sigma_{\mathrm{u}}^{+}\right)+\mathrm{e}, \\
& \text { P476: } \mathrm{N}_{2}\left(B^{3} \Pi_{\mathrm{g}}\right) \rightarrow \mathrm{N}_{2}\left(A^{3} \Sigma_{\mathrm{u}}^{+}\right)+h v_{1}, \\
& \text { P192: } \mathrm{N}_{2}\left(B^{3} \Pi_{\mathrm{g}}\right)+\mathrm{N}_{2} \rightarrow \mathrm{N}_{2}\left(A^{3} \Sigma_{\mathrm{u}}^{+}\right)+\mathrm{N}_{2},
\end{aligned}
$$

while at $78 \mathrm{~km}, \mathrm{P} 476$ dominates followed by P11 and P192. The loss channels before $5 \mu$ s are, for all the altitudes analysed, three different collisional de-excitation channels that are (in order of importance)

$$
\begin{aligned}
& \mathrm{P} 196: \mathrm{N}_{2}\left(A^{3} \Sigma_{\mathrm{u}}^{+}\right)+\mathrm{O}_{2} \rightarrow \mathrm{N}_{2}+2 \mathrm{O}, \\
& \text { P197: } \mathrm{N}_{2}\left(A^{3} \Sigma_{\mathrm{u}}^{+}\right)+\mathrm{O}_{2} \rightarrow \mathrm{N}_{2} \mathrm{O}+\mathrm{O},
\end{aligned}
$$

followed by a process with a much weaker rate than that of P196 and P197:

$$
\text { P195: } \mathrm{N}_{2}\left(A^{3} \Sigma_{\mathrm{u}}^{+}\right)+\mathrm{N}_{2} \rightarrow 2 \mathrm{~N}_{2} .
$$

Right in the middle of the plateau region (at about $0.1 \mathrm{~ms}$ ), the electron-driven excitation process $\mathrm{P} 11$ is not important anymore and P476 and P192 become the dominant source terms contributing to $\mathrm{N}_{2}\left(A^{3} \Sigma_{\mathrm{u}}^{+}\right)$at the three altitudes considered. The losses at this time $(0.1 \mathrm{~ms})$ are controlled by the same mechanisms (and order of importance) as during the pulse. Finally, at around $5 \mathrm{~ms}$, the production channels of $\mathrm{N}_{2}\left(A^{3} \Sigma_{\mathrm{u}}^{+}\right)$are negligible while the reactions $\mathrm{P} 196, \mathrm{P} 197$ and P195 reach high rates of around $10^{9} \mathrm{~cm}^{-3} \mathrm{~s}^{-1}, 10^{7} \mathrm{~cm}^{-3} \mathrm{~s}^{-1}$ and $10^{4} \mathrm{~cm}^{-3} \mathrm{~s}^{-1}$, respectively, which produce a quick decay of the $\mathrm{N}_{2}\left(A^{3} \Sigma_{\mathrm{u}}^{+}\right)$concentration at $63 \mathrm{~km}, 68 \mathrm{~km}$ and a not so abrupt decrease at $78 \mathrm{~km}$.

The concentration profiles of $\mathrm{N}_{2}\left(a^{\prime} \Sigma_{\mathrm{u}}^{-}\right)$at different altitudes represented as a function of time are shown in figure 22. We see again a sharp rise during the electric pulse and a subsequent decay where the plateau regions are now much shorter than in the case of $\mathrm{N}_{2}\left(A^{3} \Sigma_{\mathrm{u}}^{+}\right)$. The maximum values of the $\mathrm{N}_{2}\left(a^{\prime}{ }^{1} \Sigma_{\mathrm{u}}^{-}\right)$concentrations are reached right at the end of the pulse $(\sim 5 \mu \mathrm{s})$, with $63 \mathrm{~km}$ the altitude with the greatest predicted $\mathrm{N}_{2}\left(a^{\prime}{ }^{1} \Sigma_{\mathrm{u}}^{-}\right)$values. It is also interesting to note that, at a certain altitude, the transient of $\mathrm{N}_{2}\left(a^{\prime}{ }^{1} \Sigma_{\mathrm{u}}^{-}\right)$is faster (in approximately one order of magnitude) than that of $\mathrm{N}_{2}\left(A^{3} \Sigma_{u}^{+}\right)$. Before the end of the electric pulse $(<5 \mu \mathrm{s})$, the main production channels of $\mathrm{N}_{2}\left(a^{\prime 1} \Sigma_{\mathrm{u}}^{-}\right)$at 63,68 and $78 \mathrm{~km}$

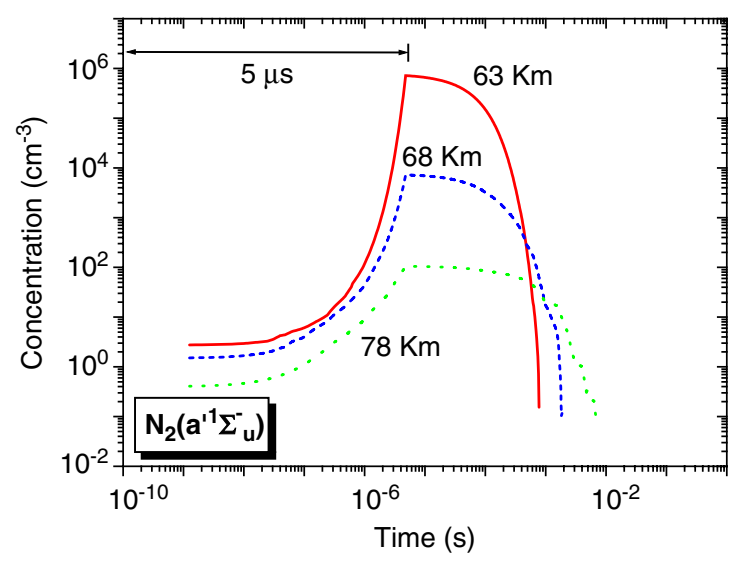

Figure 22. Time-dependent behaviour of the concentration of $\mathrm{N}_{2}\left(a^{\prime}{ }^{1} \Sigma_{\mathrm{u}}^{-}\right)$under the conditions of a single sprite event for three different altitudes. The lines indicate the same as in figure 1.

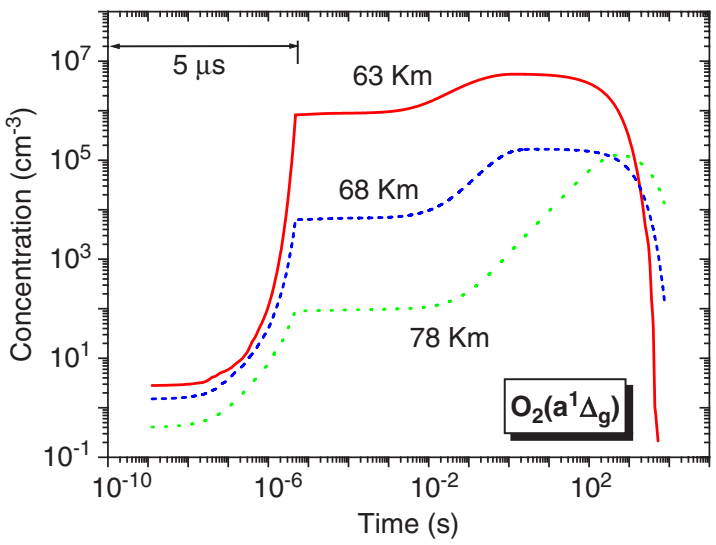

Figure 23. Time-dependent behaviour of the concentration of $\mathrm{O}_{2}\left(a^{1} \Delta_{\mathrm{g}}\right)$ under the conditions of a single sprite event for three different altitudes. The lines indicate the same as in figure 1.

are electron-impact excitation of ground state $\mathrm{N}_{2}$ followed by the collisional de-excitation of $\mathrm{N}_{2}\left(C^{3} \Pi_{\mathrm{u}}\right)$ :

$$
\begin{aligned}
& \mathrm{P} 13: \mathrm{N}_{2}+\mathrm{e} \rightarrow \mathrm{N}_{2}\left(\mathrm{a}^{\prime}{ }^{1} \Sigma_{\mathrm{u}}^{-}\right)+\mathrm{e}, \\
& \text { P190: } \mathrm{N}_{2}\left(\mathrm{C}^{3} \Pi_{\mathrm{u}}\right)+\mathrm{N}_{2} \rightarrow \mathrm{N}_{2}\left(\mathrm{a}^{\prime 1} \Sigma_{\mathrm{u}}^{-}\right)+\mathrm{N}_{2},
\end{aligned}
$$

where, in general, the rate of P190 is much lower (about two orders of magnitude) than that of P13. The loss channels of $\mathrm{N}_{2}\left(a^{\prime 1} \Sigma_{\mathrm{u}}^{-}\right)$before $5 \mu \mathrm{s}$ are, for all the altitudes analysed, three different collisional de-excitation channels that are (in order of importance)

$$
\begin{aligned}
& \mathrm{P} 186: \mathrm{N}_{2}\left(\mathrm{a}^{\prime} \Sigma_{\mathrm{u}}^{-}\right)+\mathrm{O}_{2} \rightarrow \mathrm{N}_{2}+2 \mathrm{O}, \\
& \text { P185: } \mathrm{N}_{2}\left(\mathrm{a}^{\prime} \Sigma_{\mathrm{u}}^{-}\right)+\mathrm{N}_{2} \rightarrow \mathrm{N}_{2}\left(\mathrm{~B}^{3} \Pi_{\mathrm{g}}\right)+\mathrm{N}_{2}
\end{aligned}
$$

and the almost negligible (in comparison with P186 and P185)

$$
\text { P187: } \mathrm{N}_{2}\left(\mathrm{a}^{\prime 1} \Sigma_{\mathrm{u}}^{-}\right)+\mathrm{NO} \rightarrow \mathrm{N}_{2}+\mathrm{N}+\mathrm{O},
$$

When the pulse is over (time $>5 \mu \mathrm{s}$ ), the process $\mathrm{P} 13$ is still of some importance until $0.1 \mathrm{~ms}$ at $63 \mathrm{~km}$, while all the gain reactions of $\mathrm{N}_{2}\left(a^{\prime}{ }^{1} \Sigma_{\mathrm{u}}^{-}\right)$(including P13) become unimportant when compared with the removal mechanism that around this time $(\sim 0.1 \mathrm{~ms})$ starts to control the kinetics of $\mathrm{N}_{2}\left(a^{\prime 1} \Sigma_{\mathrm{u}}^{-}\right)$.

We have represented in figures 23 and 24 the profiles corresponding to the concentrations of $\mathrm{O}_{2}\left(a^{1} \Delta_{\mathrm{g}}\right)$ and 


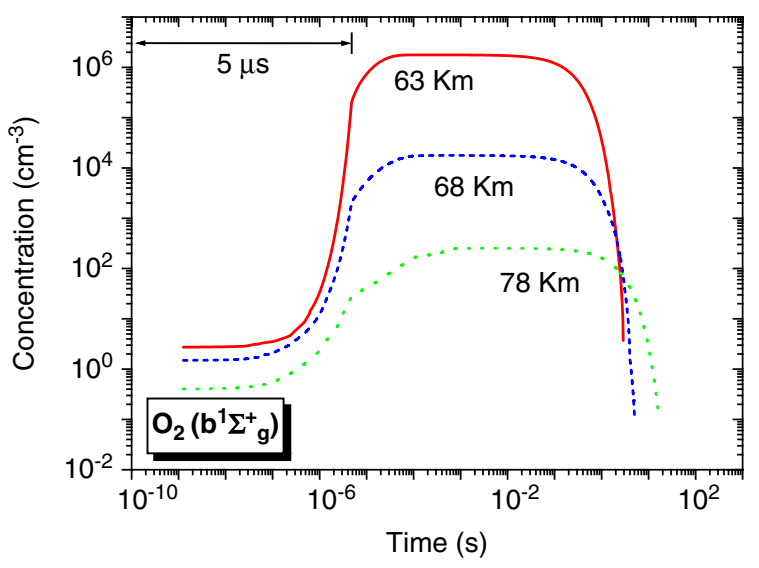

Figure 24. Time-dependent behaviour of the concentration of $\mathrm{O}_{2}\left(b^{1} \Sigma_{\mathrm{g}}^{+}\right)$under the conditions of a single sprite event for three different altitudes. The lines indicate the same as in figure 1.

$\mathrm{O}_{2}\left(b^{1} \Sigma_{\mathrm{g}}^{+}\right)$, respectively. A common feature in both cases is the long transient that they exhibit, the longest one being associated with $\mathrm{O}_{2}\left(a^{1} \Delta_{\mathrm{g}}\right)$. Both species keep having high values for quite a long time period after the pulse is off and, in the case of $\mathrm{O}_{2}\left(a^{1} \Delta_{\mathrm{g}}\right)$, it even exhibits a moderate growth before its final decay. After the pulse, the highest values $\left(\sim 10^{6} \mathrm{~cm}^{-3}\right)$ of $\mathrm{O}_{2}\left(a^{1} \Delta_{\mathrm{g}}\right)$ and $\mathrm{O}_{2}\left(b^{1} \Sigma_{\mathrm{g}}^{+}\right)$take place at $63 \mathrm{~km}$, while their lowest values $\left(\sim 10^{2} \mathrm{~cm}^{-3}\right)$ are predicted to occur at $78 \mathrm{~km}$. Before the electric pulse finishes $(<5 \mu \mathrm{s})$, the production of $\mathrm{O}_{2}\left(a^{1} \Delta_{\mathrm{g}}\right)$ is controlled by

$$
\begin{aligned}
& \mathrm{P} 22: \mathrm{O}_{2}+\mathrm{e} \rightarrow \mathrm{O}_{2}\left(\mathrm{a}^{1} \Delta_{\mathrm{g}}\right)+\mathrm{e}, \\
& \text { P206: } \mathrm{O}\left({ }^{1} \mathrm{D}\right)+\mathrm{O}_{2} \rightarrow \mathrm{O}+\mathrm{O}_{2}\left(\mathrm{a}^{1} \Delta_{\mathrm{g}}\right),
\end{aligned}
$$

while the removal of $\mathrm{O}_{2}\left(a^{1} \Delta_{\mathrm{g}}\right)$ at 63 and $68 \mathrm{~km}$ is mainly due to

$$
\begin{aligned}
& \mathrm{P} 229: \mathrm{O}_{2}\left(a^{1} \Delta_{\mathrm{g}}\right)+\mathrm{O}_{2} \rightarrow \mathrm{O}_{2}+\mathrm{O}_{2}, \\
& \text { P230: } \mathrm{O}_{2}\left(a^{1} \Delta_{\mathrm{g}}\right)+\mathrm{N}_{2} \rightarrow \mathrm{O}_{2}+\mathrm{N}_{2}
\end{aligned}
$$

with the latter being replaced by P233: $\mathrm{O}_{2}\left(a^{1} \Delta_{\mathrm{g}}\right)+\mathrm{NO} \rightarrow$ $\mathrm{NO}+\mathrm{O}_{2}$ at $78 \mathrm{~km}$.

At around $10 \mathrm{~ms}$, when a second smoother (than the first sharp rise during the pulse time) growth takes place, the reactions controlling the generation of $\mathrm{O}_{2}\left(a^{1} \Delta_{\mathrm{g}}\right)$ at $63 \mathrm{~km}$ are mainly

$$
\begin{aligned}
& \text { P234: } \mathrm{O}_{2}\left(b^{1} \Sigma_{\mathrm{g}}^{+}\right)+\mathrm{N}_{2} \rightarrow \mathrm{O}_{2}\left(a^{1} \Delta_{\mathrm{g}}\right)+\mathrm{N}_{2}, \\
& \text { P22: } \mathrm{O}_{2}+\mathrm{e} \rightarrow \mathrm{O}_{2}\left(a^{1} \Delta_{\mathrm{g}}\right)+\mathrm{e}, \\
& \text { P237: } \mathrm{O}_{2}\left(b^{1} \Sigma_{\mathrm{g}}^{+}\right)+\mathrm{O}_{3} \rightarrow 2 \mathrm{O}_{2}\left(a^{1} \Delta_{\mathrm{g}}\right)+\mathrm{O},
\end{aligned}
$$

while at 68 and $78 \mathrm{~km} \mathrm{P} 22$ is the most important followed by $\mathrm{P} 234$. The losses of $\mathrm{O}_{2}\left(a^{1} \Delta_{\mathrm{g}}\right)$ at all the altitudes around $10 \mathrm{~ms}$ are due to the same channels mentioned above for times prior to the end of the pulse. From this moment on, these loss mechanisms keep growing so that they become dominant (over the gain channels) and produce a visible decrease in $\mathrm{O}_{2}\left(a^{1} \Delta_{\mathrm{g}}\right)$ from about $500 \mathrm{~s}$.

The behaviour of the concentration of $\mathrm{O}_{2}\left(b^{1} \Sigma_{\mathrm{g}}^{+}\right)$is shown in figure 24. The trend is a bit different with regard to that

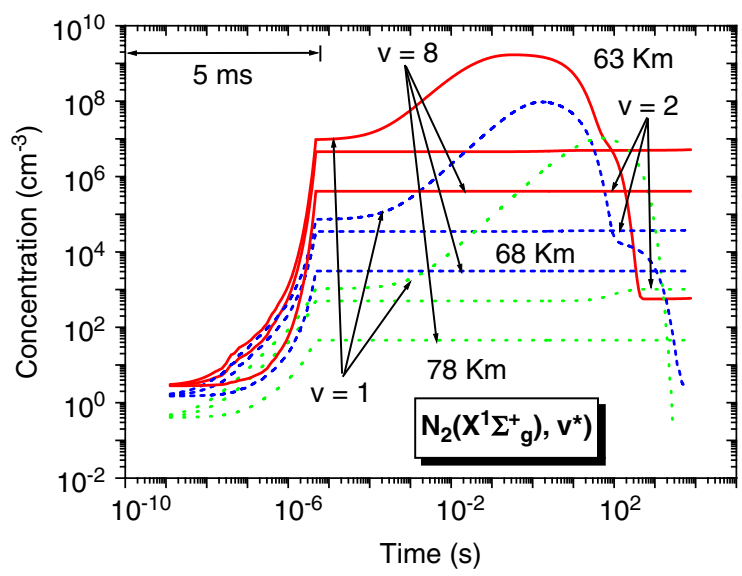

Figure 25. Time-dependent behaviour of the concentration of the first eight vibrationally excited levels of the ground electronic state of $\mathrm{N}_{2}$ under the conditions of a single sprite event for three different altitudes. The lines indicate the same as in figure 1.

of $\mathrm{O}_{2}\left(a^{1} \Delta_{\mathrm{g}}\right)$ since there is no further growth starting in the plateau region (as in the case of $\mathrm{O}_{2}\left(a^{1} \Delta_{\mathrm{g}}\right)$ ). Before the electric pulse finishes $(<5 \mu \mathrm{s})$, the production of $\mathrm{O}_{2}\left(b^{1} \Sigma_{\mathrm{g}}^{+}\right)$ is controlled by

$$
\begin{aligned}
& \mathrm{P} 23: \mathrm{O}_{2}+\mathrm{e} \rightarrow \mathrm{O}_{2}\left(b^{1} \Sigma_{\mathrm{g}}^{+}\right)+\mathrm{e} \\
& \text { P205: } \mathrm{O}\left({ }^{1} \mathrm{D}\right)+\mathrm{O}_{2} \rightarrow \mathrm{O}+\mathrm{O}_{2}\left(b^{1} \Sigma_{\mathrm{g}}^{+}\right)
\end{aligned}
$$

and the losses are driven by P234: $\mathrm{O}_{2}\left(b^{1} \Sigma_{\mathrm{g}}^{+}\right)+\mathrm{N}_{2} \rightarrow$ $\mathrm{O}_{2}\left(a^{1} \Delta_{\mathrm{g}}\right)+\mathrm{N}_{2}$.

At around $10 \mathrm{~ms}$, in the middle of the plateau, the main production mechanism of $\mathrm{O}_{2}\left(b^{1} \Sigma_{\mathrm{g}}^{+}\right)$is P205 and the losses at $63 \mathrm{~km}$ are due to $\mathrm{P} 234$ closely followed by P237 and by P436: $\mathrm{O}_{2}\left(b^{1} \Sigma_{\mathrm{g}}^{+}\right)+\mathrm{H}_{2} \mathrm{O} \rightarrow \mathrm{O}_{2}+\mathrm{H}_{2} \mathrm{O}$ (at 68 and $78 \mathrm{~km}$ ). At $0.1 \mathrm{~s}$, the rates of the latter removal mechanisms of $\mathrm{O}_{2}\left(b^{1} \Sigma_{\mathrm{g}}^{+}\right)$ become much higher than those of the production reactions and, consequently, the density of $\mathrm{O}_{2}\left(b^{1} \Sigma_{\mathrm{g}}^{+}\right)$starts to decrease.

Finally, we have included in figure 25 the time-dependent behaviour of the first eight vibrationally excited levels of the ground electronic state of $\mathrm{N}_{2}$. The sharp increase during the electric pulse is a common feature of the eight vibrational levels. During the pulse (time $\leqslant 5 \mu \mathrm{s}$ ), the vibrational levels $v_{\mathrm{i}}$ are populated due to the electron-impact vibrational excitation mechanism of the type P3: $\mathrm{N}_{2}+\mathrm{e} \leftrightarrow \mathrm{N}_{2}\left(v_{i}\right)+\mathrm{e} ;(i=1, \ldots, 8)$ and where superelastic collisions are also considered. The loss channels of levels $v_{1}$ and $v_{j}(j=2, \ldots, 8)$ are not exactly the same because, for $v_{1}$, the dominant loss reactions are

$$
\text { P156: } \mathrm{N}_{2}\left(v_{1}\right)+\mathrm{CO}_{2} \rightarrow \mathrm{CO}_{2}\left(\begin{array}{lll}
0 & 0 & 1)
\end{array}\right)+\mathrm{N}_{2}
$$

followed by P4: $\mathrm{N}_{2}\left(v_{1}\right)+\mathrm{e} \leftrightarrow \mathrm{N}_{2}\left(v_{2}\right)+\mathrm{e}$, which has a much lower rate than P156. However, for $v_{j}(j=2, \ldots, 8)$, the main loss channels are $\mathrm{N}_{2}\left(v_{i}\right)+\mathrm{e} \leftrightarrow \mathrm{N}_{2}\left(v_{i+1}\right)+$ e closely followed by vibrational-translational processes of the form $\mathrm{N}_{2}\left(v_{i+1}\right)+\mathrm{N}_{2} \rightarrow \mathrm{N}_{2}\left(v_{i}\right)+\mathrm{N}_{2}$.

When the pulse is over (time $>5 \mu \mathrm{s}$ ), the $\mathrm{P} 3$ reaction controlling the production of $\mathrm{N}_{2}\left(v_{1}\right)$ is very closely followed by the reaction P157: $\mathrm{N}_{2}+\mathrm{CO}_{2}(001) \rightarrow \mathrm{CO}_{2}+\mathrm{N}_{2}\left(v_{1}\right)$ 
so that a further increase in $\mathrm{N}_{2}\left(v_{1}\right)$ is visible. However, P157 does not play any role in generating $\mathrm{N}_{2}\left(v_{i}\right)(\mathrm{i}=2, \ldots, 8)$ states whose production by $\mathrm{N}_{2}\left(v_{i+1}\right)+\mathrm{N}_{2} \rightarrow \mathrm{N}_{2}\left(v_{\mathrm{i}}\right)+\mathrm{N}_{2}$ and loss by $\mathrm{N}_{2}\left(v_{i}\right)+\mathrm{N}_{2} \rightarrow \mathrm{N}_{2}\left(v_{i-1}\right)+\mathrm{N}_{2}$ are balanced and result in the flat trend exhibited by the concentrations of $\mathrm{N}_{2}\left(v_{i}\right)(i=2, \ldots, 8)$ after the pulse. At around $10 \mathrm{~s}$, the only important production channel of $\mathrm{N}_{2}\left(v_{1}\right)$ is P157, but its losses due to P156: $\mathrm{N}_{2}\left(v_{1}\right)+\mathrm{CO}_{2} \rightarrow \mathrm{CO}_{2}(001)+\mathrm{N}_{2}$ are so high as to produce the lowering of the concentration of $\mathrm{N}_{2}\left(v_{1}\right)$. In a first approximation, the vibrational kinetics of sprite plasmas can be studied by neglecting higher order vibrational-vibrational processes such as, $\mathrm{N}\left(v_{3}\right)+\mathrm{N}\left(v_{4}\right)$ or $\mathrm{N}\left(v_{2}\right)+\mathrm{N}\left(v_{5}\right)$.

\subsection{Visible, ultraviolet and infrared optical emissions}

In this section, we discuss the results of the present kinetic model in connection with the optical emissions associated with the atomic, ionic and molecular species that are excited as a consequence of the passage of a fast electric pulse through the Earth mesosphere. The radiative de-excitation of the excited species causes the appearance of optical flashes in different regions of the electromagnetic spectrum. The goal here is to provide some preliminary insight about the underlying kinetic processes of some of the most important UV, visible and IR emissions from sprite streamer heads. There have been several reports on the identification of some of these emissions in the spectra recorded from sprites; however, there are very few works trying to establish quantitative relationships between the sprite chemical activity and their light emissions. In addition, we have included the impact of the altitude $(63,68$ and $78 \mathrm{~km})$ on the relative importance of the different time-dependent optical emissions analysed. So far, similar analyses were only undertaken at around $70 \mathrm{~km}$ high. In all the cases we have evaluated the emission brightness (EB), measured in Rayleighs (R), through the classical expression [120]

$$
\mathrm{EB}(R)=10^{-6} \int_{L} V(l) \mathrm{d} l
$$

valid for the optically thin case and where $V(l)$ is the so-called volume emission rate (in photons $\mathrm{cm}^{-3} \mathrm{~s}^{-1}$ ) and the integral is taken along the line of sight through the emission volume over an effective column length $L$. In general, following [57], the observations are assumed to be made perpendicularly to the streamer axis and, consequently, the magnitude $L$ refers to the diameter of the 'trailing column' of the streamer. We have assumed in all the calculations that $L$, the emission column length, is equal to $\sim 25 \mathrm{~m}$ as in [57]. The volume emission rate $V(l)$ is equal to the product $A_{k}\left(\mathrm{~s}^{-1}\right) \times N_{k}\left(\mathrm{~cm}^{-3}\right)$, that is, the product of the Einstein coefficients $\left(A_{k}\right)$ for spontaneous emission and the concentration $\left(N_{k}\right)$ of the emitting excited state $k$.

\subsection{Visible emissions.}

In the present model, the visible transitions evaluated are associated with processes $\mathrm{P} 476\left(\mathrm{~N}_{2}\right.$ first negative system) producing the characteristic red colour of sprite spectral emissions, P477 $\left(\mathrm{N}_{2}\right.$ second positive system) and P478 $\left(\mathrm{N}_{2}^{+}\right.$

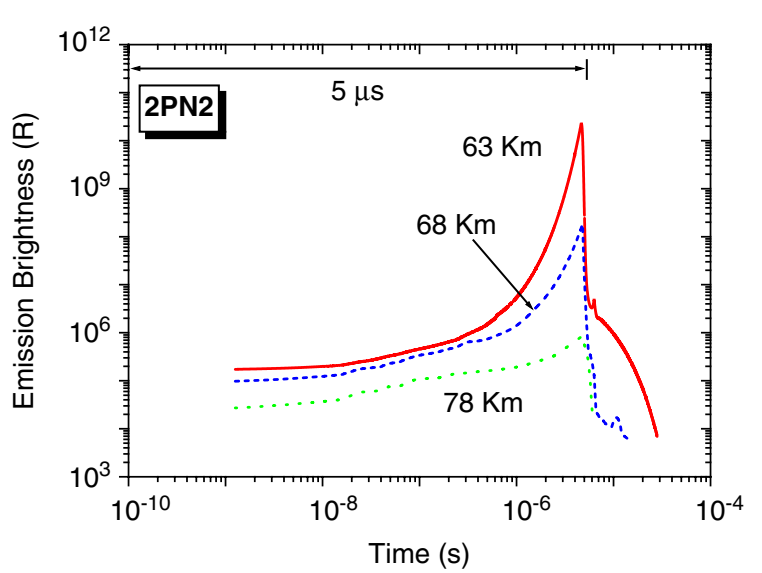

Figure 26. Time-dependent behaviour of the emission brightness of $2 \mathrm{PN}_{2}$ under the conditions of a single sprite event for three different altitudes. The lines indicate the same as in figure 1 .

first negative band) both contributing to the observed bluish sprite emission, P484 and P485. It is important to note that the transition probabilities considered for the $1 \mathrm{PN}_{2}, 2 \mathrm{PN}_{2}$ and the $\mathrm{N}_{2}^{+} 1 \mathrm{NG}$ systems are all approximate averages over the vibrational of the initial (emitting) electronic state [69]. The same transition probability as for the ground vibrational level has been assumed for all vibrational levels of the corresponding emitting electronic states $\left(B^{3} \Pi_{\mathrm{g}}\right.$ and $C^{3} \Pi_{\mathrm{u}}$ of $\left.\mathrm{N}_{2}\right)$ because, in general, the $v^{\prime}=0$ level has the maximum population and the transition probabilities of many electronic transitions and, in particular, of those involving $\mathrm{N}_{2}\left(B^{3} \Pi_{\mathrm{g}}\right)$ and $\mathrm{N}_{2}\left(C^{3} \Pi_{\mathrm{u}}\right)$ are usually weakly dependent on the $v^{\prime}$ levels [69].

The time-dependent emission brightness due to the second positive band system of $\mathrm{N}_{2}\left(2 \mathrm{PN}_{2}\right)$ is shown in figure 26. The maximum value of the brightness of $2 \mathrm{PN}_{2}$ is reached right at the end of the pulse at $5 \mu$ s for the three altitudes studied. The highest value ( $\sim 20 \mathrm{GR})$ is found at $63 \mathrm{~km}$ and the lowest ( $\sim 1 \mathrm{MR})$ at $78 \mathrm{~km}$, while at $68 \mathrm{~km}$ it reaches $100 \mathrm{MR}$. The emission brightness decays quite fast when the electric pulse is off. We have taken into consideration two production and three loss mechanisms underlying the concentration of $\mathrm{N}_{2}\left(C^{3} \Pi_{\mathrm{u}}\right)$. During the pulse (time $\left.\leqslant 5 \mu \mathrm{s}\right), \mathrm{N}_{2}\left(C^{3} \Pi_{\mathrm{u}}\right)$ is produced mainly by

$$
\mathrm{P} 15: \mathrm{N}_{2}+\mathrm{e} \rightarrow \mathrm{N}_{2}\left(C^{3} \Pi_{\mathrm{u}}\right)+\mathrm{e}
$$

followed by P166 : $\operatorname{Ar}\left({ }^{3} \mathrm{P}_{2}\right)+\mathrm{N}_{2} \rightarrow \operatorname{Ar}+\mathrm{N}_{2}\left(C^{3} \Pi_{\mathrm{u}}\right)$ with a reaction rate much weaker than that of P15. The losses of $\mathrm{N}_{2}\left(C^{3} \Pi_{\mathrm{u}}\right)$ before the pulse is off are driven by its radiative de-excitation:

$$
\begin{aligned}
\mathrm{P} 477 & : \mathrm{N}_{2}\left(C^{3} \Pi_{\mathrm{u}}\left(v^{\prime}=0,1,1,2\right)\right) \rightarrow \mathrm{N}_{2}\left(B^{3} \Pi_{\mathrm{g}}\right. \\
& \left.\times\left(v^{\prime \prime}=4,5,4,6\right)\right)+h v_{2},
\end{aligned}
$$

followed by weaker quenching reactions with $\mathrm{O}_{2}$ and $\mathrm{N}_{2}$ :

$$
\begin{aligned}
& \text { P191: } \mathrm{N}_{2}\left(C^{3} \Pi_{\mathrm{u}}\right)+\mathrm{O}_{2} \rightarrow \mathrm{N}_{2}+\mathrm{O}+\mathrm{O}\left({ }^{1} \mathrm{~S}\right), \\
& \text { P190: } \mathrm{N}_{2}\left(C^{3} \Pi_{\mathrm{u}}\right)+\mathrm{N}_{2} \rightarrow \mathrm{N}_{2}\left(a^{\prime}{ }^{1} \Sigma_{\mathrm{u}}^{-}\right)+\mathrm{N}_{2} .
\end{aligned}
$$

When the pulse is over (time $>5 \mu \mathrm{s}$ ), P166 becomes the dominant channel generating $\mathrm{N}_{2}\left(C^{3} \Pi_{\mathrm{u}}\right)$ followed by the much 


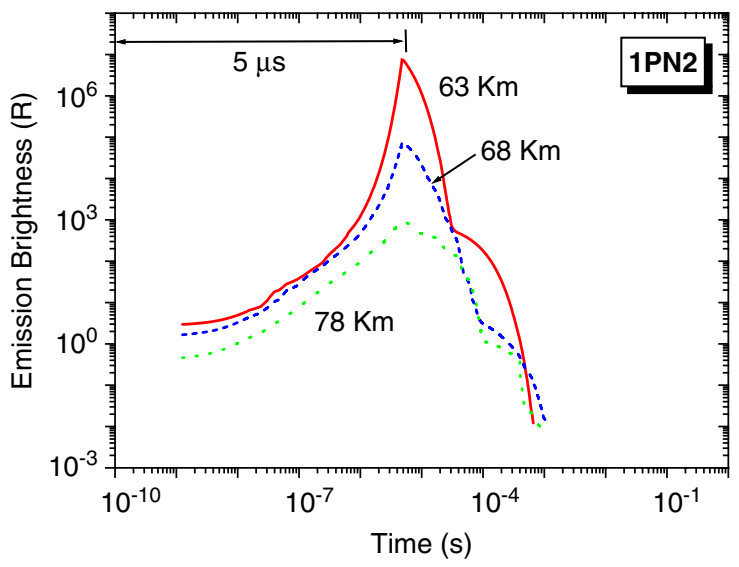

Figure 27. Time-dependent behaviour of the emission brightness of $1 \mathrm{PN}_{2}$ under the conditions of a single sprite event for three different altitudes. The lines indicate the same as in figure 1 .

less important P15. The losses at this time are the same processes as during the pulse but, now, the removal reactions P477, P191 and P190 have much greater rates than those of the production processes. The relative importance of the above processes is the same for the three heights considered. It will be like this hereafter if no comment is specifically made.

The bluish radiative emission of the first positive band system of $\mathrm{N}_{2}\left(1 \mathrm{PN}_{2}\right)$ is represented in figure 27 . The trend followed is similar to that of $2 \mathrm{PN}_{2}$ but with two distinct features which are that the transient exhibited by the emission brightness of $1 \mathrm{PN}_{2}$ is longer than that of $2 \mathrm{PN}_{2}$ and that the $1 \mathrm{PN}_{2}$ brightness reaches significantly lower values than the one of $2 \mathrm{PN}_{2}$. Before the pulse is off (time $\left.\leqslant 5 \mu \mathrm{s}\right), \mathrm{N}_{2}\left(B^{3} \Pi_{\mathrm{g}}\right)$ is generated by radiative de-excitation of $\mathrm{N}_{2}\left(C^{3} \Pi_{\mathrm{u}}\right)$ represented by process $\mathrm{P} 477$ closely followed by reaction P14 (electronimpact excitation of ground $\mathrm{N}_{2}$ ). The collisional de-excitation P185: $\mathrm{N}_{2}\left(a^{\prime} \Sigma_{\mathrm{u}}^{-}\right)+\mathrm{N}_{2} \rightarrow \mathrm{N}_{2}\left(B^{3} \Pi_{\mathrm{g}}\right)+\mathrm{N}_{2}$ is of secondary importance (in comparison with $\mathrm{P} 477$ and $\mathrm{P} 14$ ) in producing $\mathrm{N}_{2}\left(C^{3} \Pi_{\mathrm{u}}\right)$. The losses of $\mathrm{N}_{2}\left(B^{3} \Pi_{\mathrm{g}}\right)$ before the pulse is off (time $\leqslant 5 \mu \mathrm{s}$ ) at $63 \mathrm{~km}$ are controlled (in order of importance) by

P194: $\mathrm{N}_{2}\left(B^{3} \Pi_{\mathrm{g}}\right)+\mathrm{O}_{2} \rightarrow \mathrm{N}_{2}+\mathrm{O}+\mathrm{O}$,

P476: $\mathrm{N}_{2}\left(B^{3} \Pi_{\mathrm{g}}\left(v^{\prime}=6,7,6,7\right)\right)$

$\rightarrow N_{2}\left(A^{3} \Sigma_{u}^{+}\left(v^{\prime \prime}=3,4,2,3\right)\right)+h v_{1}$,

P192: $\mathrm{N}_{2}\left(B^{3} \Pi_{\mathrm{g}}\right)+\mathrm{N}_{2} \rightarrow \mathrm{N}_{2}\left(A^{3} \Sigma_{\mathrm{u}}^{+}\right)+\mathrm{N}_{2}$

and by the weaker process P193: $\mathrm{N}_{2}\left(B^{3} \Pi_{\mathrm{g}}\right)+\mathrm{N}_{2} \rightarrow 2 \mathrm{~N}_{2}$. However, at 68 and $78 \mathrm{~km}, \mathrm{P} 476$ becomes the first removal process of $\mathrm{N}_{2}\left(B^{3} \Pi_{\mathrm{g}}\right)$ followed by P194.

Once the pulse is over (time $>5 \mu \mathrm{s}$ ), at $63 \mathrm{~km}, \mathrm{P} 185$ : $\mathrm{N}_{2}\left(a^{\prime 1} \Sigma_{\mathrm{u}}^{-}\right)+\mathrm{N}_{2} \rightarrow \mathrm{N}_{2}\left(B^{3} \Pi_{\mathrm{g}}\right)+\mathrm{N}_{2}$ becomes the most important production channel of $\mathrm{N}_{2}\left(B^{3} \Pi_{\mathrm{g}}\right)$ followed by the radiative decay of $\mathrm{N}_{2}\left(C^{3} \Pi_{\mathrm{u}}\left(v^{\prime}=0,1,1,2\right)\right)(\mathrm{P} 477)$. At 68 and $78 \mathrm{~km}$, the dominant source terms of $\mathrm{N}_{2}\left(B^{3} \Pi_{\mathrm{g}}\right)$ are $\mathrm{P} 477$ first and then $\mathrm{P} 185$. The losses at this time are the same processes as during the pulse.

The emission brightness of the violet light $(\sim 427 \mathrm{~nm})$ coming from the radiative de-excitation of the first negative

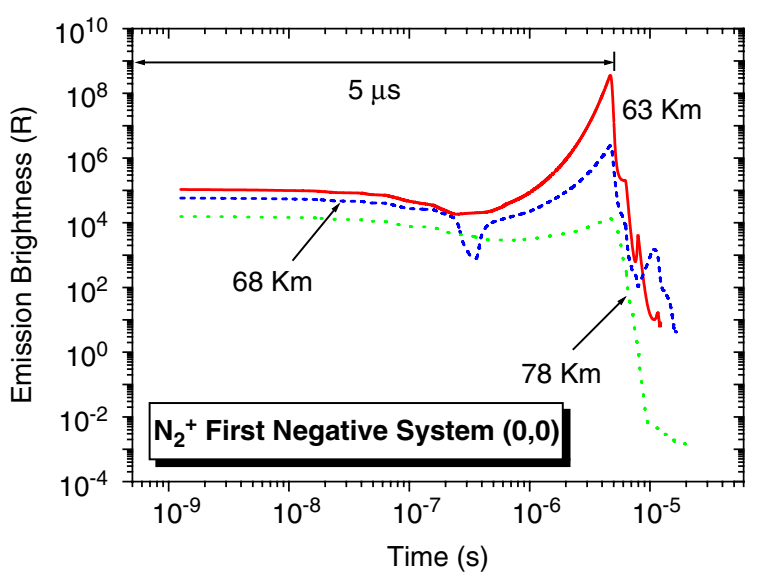

Figure 28. Time-dependent behaviour of the emission brightness of the first negative band system of $\mathrm{N}_{2}^{+}$under the conditions of a single sprite event for three different altitudes. The lines indicate the same as in figure 1 .

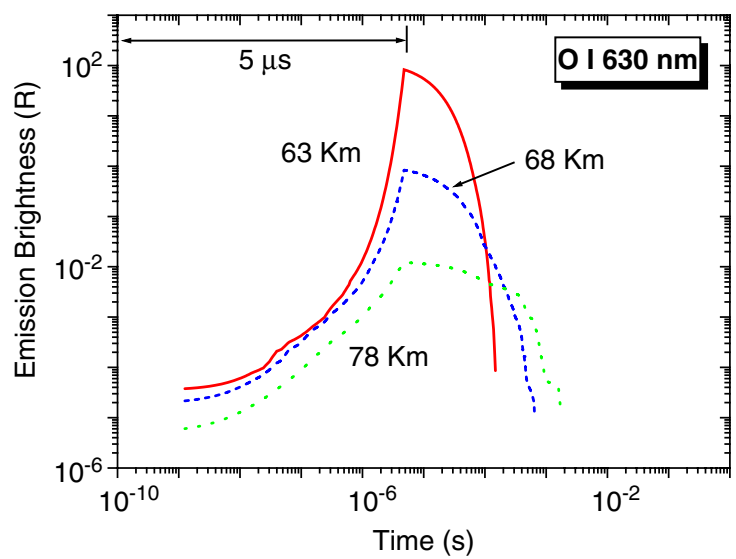

Figure 29. Time-dependent behaviour of the emission brightness of $\mathrm{O}\left({ }^{1} \mathrm{D}\right)$ under the conditions of a single sprite event for three different altitudes. The lines indicate the same as in figure 1.

band system of $\mathrm{N}_{2}^{+}$is shown in figure 28. The maximum brightness is reached right at the end of the electric pulse $(\sim 5 \mu \mathrm{s})$ and it occurs at $63 \mathrm{~km}(\sim 1 \mathrm{GR})$, followed by the highest value predicted for $68 \mathrm{~km}(\sim 1 \mathrm{MR})$ and, finally, for the lowest brightness of $(\sim 10 \mathrm{kR})$ taking place at $78 \mathrm{~km}$. The generation of $\mathrm{N}_{2}^{+}\left(B^{2} \Sigma_{\mathrm{u}}^{+}\right)$is due to the electron-impact reaction $\mathrm{P} 17: \mathrm{N}_{2}+\mathrm{e} \rightarrow \mathrm{N}_{2}^{+}\left(B^{2} \Sigma_{\mathrm{u}}^{+}\right)+2 \mathrm{e}$ which, when the pulse is over, becomes negligible in comparison with the loss of $\mathrm{N}_{2}^{+}\left(B^{2} \Sigma_{\mathrm{u}}^{+}\right)$ due to its radiative decay P478: $\mathrm{N}_{2}^{+}\left(B^{2} \Sigma_{\mathrm{u}}^{+}\left(v^{\prime}=0\right)\right) \rightarrow$ $\mathrm{N}_{2}^{+}\left(X^{3} \Sigma_{\mathrm{g}}^{+}\left(v^{\prime \prime}=1\right)\right)+h v_{3}$. It is interesting to note that, for the three altitudes evaluated, the transients of the first negative band system of $\mathrm{N}_{2}^{+}$are quite short lasting around $10 \mu \mathrm{s}$ and, therefore, they will not be easy to detect.

The optical emission brightnesses from the excited atomic oxygen $\mathrm{O}\left({ }^{1} \mathrm{D}\right)$ and $\mathrm{O}\left({ }^{1} \mathrm{~S}\right)$ are shown in figures 29 and 30 , respectively. The wavelengths associated with radiative decays of $\mathrm{O}\left({ }^{1} \mathrm{D}\right)$ and $\mathrm{O}\left({ }^{1} \mathrm{~S}\right)$ are, respectively, $630.0 \mathrm{~nm}$ (reddish) and $557.7 \mathrm{~nm}$ (green) and, therefore, they are both within the visible region of the electromagnetic spectrum. The emission brightnesses of $\mathrm{O}\left({ }^{1} \mathrm{D}\right)$ (see figure 28) and $\mathrm{O}\left({ }^{1} \mathrm{~S}\right)$ (see figure 30) reach their maximum values right at the end of the pulse (time $=5 \mu \mathrm{s}$ ) and they both exhibit similar values for the 


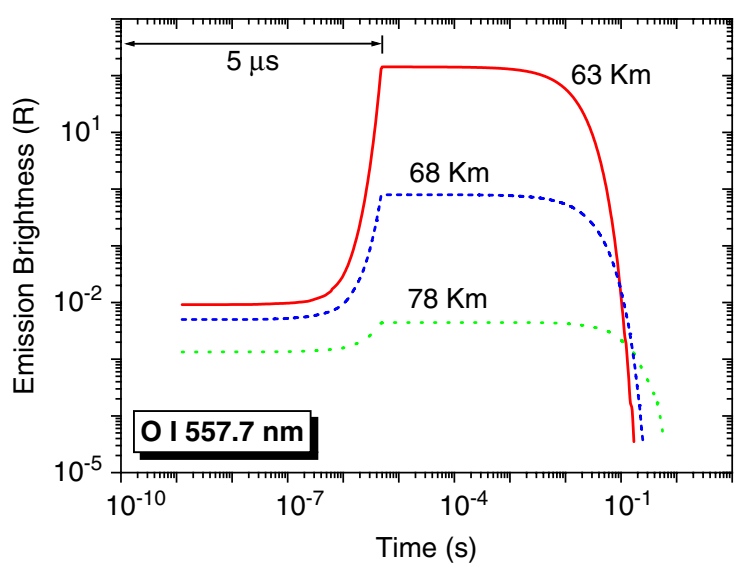

Figure 30. Time-dependent behaviour of the emission brightness of $\mathrm{O}\left({ }^{1} \mathrm{~S}\right)$ under the conditions of a single sprite event for three different altitudes. The lines indicate the same as in figure 1 .

three altitudes investigated. However, one distinct feature among them is that while the brightness of $\mathrm{O}\left({ }^{1} \mathrm{D}\right)$ starts to decrease immediately after the pulse is off, the one of $\mathrm{O}\left({ }^{1} \mathrm{~S}\right)$ remains in its highest value exhibiting a long plateau that lasts up to $\sim 10 \mathrm{~ms}$ (for 63 and $68 \mathrm{~km}$ ) and $0.1 \mathrm{~s}$ (for $78 \mathrm{~km}$ ). We have considered twelve production mechanisms for $\mathrm{O}\left({ }^{1} \mathrm{D}\right)$ and three for $\mathrm{O}\left({ }^{1} \mathrm{~S}\right)$. For taking into consideration the removal of $\mathrm{O}\left({ }^{1} \mathrm{D}\right)$ and $\mathrm{O}\left({ }^{1} \mathrm{~S}\right)$, we have included in the model eighteen and fourteen loss channels, respectively. The production of $\mathrm{O}\left({ }^{1} \mathrm{D}\right)$ during the pulse (time $\leqslant 5 \mu \mathrm{s}$ ) at 63 and $68 \mathrm{~km}$ is driven mainly by

$$
\mathrm{P} 52: \mathrm{e}+\mathrm{O}_{2} \rightarrow \mathrm{O}+\mathrm{O}\left({ }^{1} \mathrm{D}\right)+\mathrm{e},
$$

followed by the less important

$$
\begin{aligned}
& \mathrm{P} 37: \mathrm{H}_{2} \mathrm{O}+\mathrm{e} \rightarrow \mathrm{O}\left({ }^{1} \mathrm{D}\right)+\mathrm{H}_{2}+\mathrm{e}, \\
& \mathrm{P} 29: \mathrm{O}+\mathrm{e} \rightarrow \mathrm{O}\left({ }^{1} \mathrm{D}\right)+\mathrm{e},
\end{aligned}
$$

while, at $78 \mathrm{~km}, \mathrm{P} 29$ becomes the second followed by P37.

The losses of $\mathrm{O}\left({ }^{1} \mathrm{D}\right)$ before the pulse is off (time $\leqslant 5 \mu \mathrm{s}$ ) are driven mainly by

$$
\begin{aligned}
& \text { P204: } \mathrm{O}\left({ }^{1} \mathrm{D}\right)+\mathrm{N}_{2} \rightarrow \mathrm{O}+\mathrm{N}_{2}, \\
& \text { P205: } \mathrm{O}\left({ }^{1} \mathrm{D}\right)+\mathrm{O}_{2} \rightarrow \mathrm{O}+\mathrm{O}_{2}\left(b^{1} \Sigma_{\mathrm{g}}^{+}\right),
\end{aligned}
$$

followed in importance by

$$
\begin{aligned}
& \text { P206: } \mathrm{O}\left({ }^{1} \mathrm{D}\right)+\mathrm{O}_{2} \rightarrow \mathrm{O}+\mathrm{O}_{2}\left(a^{1} \Delta_{\mathrm{g}}\right), \\
& \text { P215: } \mathrm{O}\left({ }^{1} \mathrm{D}\right)+\mathrm{CO}_{2} \rightarrow \mathrm{O}+\mathrm{CO}_{2}
\end{aligned}
$$

with the radiative decay $\mathrm{P} 484: \mathrm{O}\left({ }^{1} \mathrm{D}\right) \rightarrow \mathrm{O}+h \nu_{9}$ being quite unimportant in comparison with the above-mentioned collisional deactivation mechanisms of $\mathrm{O}\left({ }^{1} \mathrm{D}\right)$.

When the electric pulse is off (time $>5 \mu \mathrm{s}$ ), the production processes of $\mathrm{O}\left({ }^{1} \mathrm{D}\right)$ at 63 and $68 \mathrm{~km}$ are now controlled by two-body electron-impact recombination processes with $\mathrm{O}_{2}^{+}$and $\mathrm{O}\left({ }^{1} \mathrm{~S}\right)$ deactivation by spontaneous radiative emission and quenching by $\mathrm{O}_{3}$ :

$$
\begin{aligned}
& \mathrm{P} 70: \mathrm{e}+\mathrm{O}_{2}^{+} \rightarrow \mathrm{O}+\mathrm{O}\left({ }^{1} \mathrm{D}\right), \\
& \mathrm{P} 71: \mathrm{e}+\mathrm{O}_{2}^{+} \rightarrow \mathrm{O}\left({ }^{1} \mathrm{D}\right)+\mathrm{O}\left({ }^{1} \mathrm{D}\right), \\
& \mathrm{P} 485: \mathrm{O}\left({ }^{1} \mathrm{~S}\right) \rightarrow \mathrm{O}\left({ }^{1} \mathrm{D}\right)+h v_{10}, \\
& \text { P224: }\left({ }^{1} \mathrm{~S}\right)+\mathrm{O}_{3} \rightarrow \mathrm{O}_{2}+\mathrm{O}+\mathrm{O}\left({ }^{1} \mathrm{D}\right) .
\end{aligned}
$$

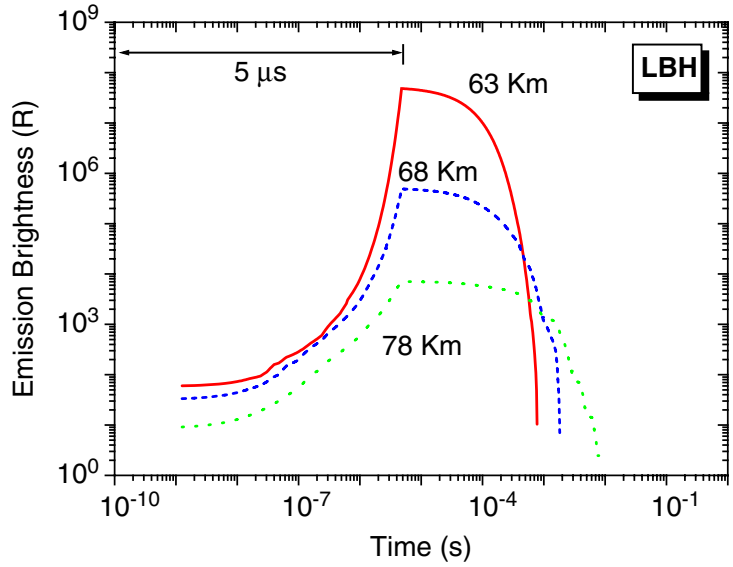

Figure 31. Time-dependent behaviour of the emission brightness of the $\mathrm{N}_{2}$ Lyman-Birge-Hopfield (LBH) under the conditions of a single sprite event for three different altitudes. The lines indicate the same as in figure 1.

However, at $78 \mathrm{~km}$, the main production channels of $\mathrm{O}\left({ }^{1} \mathrm{D}\right)$ are P485 and P70 followed by P71 and P224. The loss reactions (and relative importance) of $\mathrm{O}\left({ }^{1} \mathrm{D}\right)$ for times $>5 \mu$ s are the same as those acting during the pulse.

According to our model, the most important microscopic mechanism producing the excited state $\mathrm{O}\left({ }^{1} \mathrm{~S}\right)$ while the pulse is on (time $\leqslant 5 \mu \mathrm{s}$ ) is

$$
\text { P191: } \mathrm{N}_{2}\left(C^{3} \Pi_{\mathrm{u}}\right)+\mathrm{O}_{2} \rightarrow \mathrm{N}_{2}+\mathrm{O}+\mathrm{O}\left({ }^{1} \mathrm{~S}\right)
$$

and the losses of $\mathrm{O}\left({ }^{1} \mathrm{~S}\right)$ at 63 and $68 \mathrm{~km}$ are principally caused by

$$
\begin{aligned}
& \text { P219: } \mathrm{O}\left({ }^{1} \mathrm{~S}\right)+\mathrm{O}_{2} \rightarrow \mathrm{O}_{2}+\mathrm{O}, \\
& \text { P433: } \mathrm{O}\left({ }^{1} \mathrm{~S}\right)+\mathrm{H}_{2} \mathrm{O} \rightarrow \mathrm{OH}+\mathrm{OH}, \\
& \text { P434: } \mathrm{O}\left({ }^{1} \mathrm{~S}\right)+\mathrm{H}_{2} \mathrm{O} \rightarrow \mathrm{H}_{2}+\mathrm{O}_{2}, \\
& \text { P485: } \mathrm{O}\left({ }^{1} \mathrm{~S}\right) \rightarrow \mathrm{O}\left({ }^{1} \mathrm{D}\right)+h v_{10}
\end{aligned}
$$

while, at $78 \mathrm{~km}, \mathrm{P} 485$ becomes the second most important removal reaction of $\mathrm{O}\left({ }^{1} \mathrm{~S}\right)$ after $\mathrm{P} 219$.

When the electric pulse is off (time $>5 \mu \mathrm{s}$ ), the dominant production process leading to $\mathrm{O}\left({ }^{1} \mathrm{~S}\right)$ at $63 \mathrm{~km}$ is

$$
\text { P199: } \mathrm{N}_{2}\left(A^{3} \Sigma_{\mathrm{u}}^{+}\right)+\mathrm{O} \rightarrow \mathrm{N}_{2}+\mathrm{O}\left({ }^{1} \mathrm{~S}\right) \text {. }
$$

At $68 \mathrm{~km}$, the most important production channels of $\mathrm{O}\left({ }^{1} \mathrm{~S}\right)$ are first P191: $\mathrm{N}_{2}\left(C^{3} \Pi_{\mathrm{u}}\right)+\mathrm{O}_{2} \rightarrow \mathrm{N}_{2}+\mathrm{O}+\mathrm{O}\left({ }^{1} \mathrm{~S}\right)$ followed by $\mathrm{P} 199$ but, at $78 \mathrm{~km}, \mathrm{P} 199$ is again the dominant process now followed by $\mathrm{P} 191$. The losses of $\mathrm{O}\left({ }^{1} \mathrm{~S}\right)$ after the pulse (time $>5 \mu \mathrm{s}$ ) are the same as those acting during the pulse.

3.7.1. Ultraviolet emissions. The emission brightness of the UV emission associated with the $\mathrm{N}_{2}$ Lyman-Birge-Hopfield $(\mathrm{LBH})$ is represented in figure 31. The only previous work including a quantitative discussion on the molecular nitrogen LBH band associated with sprite streamers was published in 2005 [47] but only one altitude $(70 \mathrm{~km})$ was investigated. We see in figure 31 that the greatest LBH emission brightness is achieved at $63 \mathrm{~km}(\sim 10 \mathrm{MR})$ followed by the one at $68 \mathrm{~km}$ $(\sim 1 \mathrm{MR})$ and the lowest value $(\sim 5 \mathrm{kR})$ at $78 \mathrm{~km}$. In general, it 


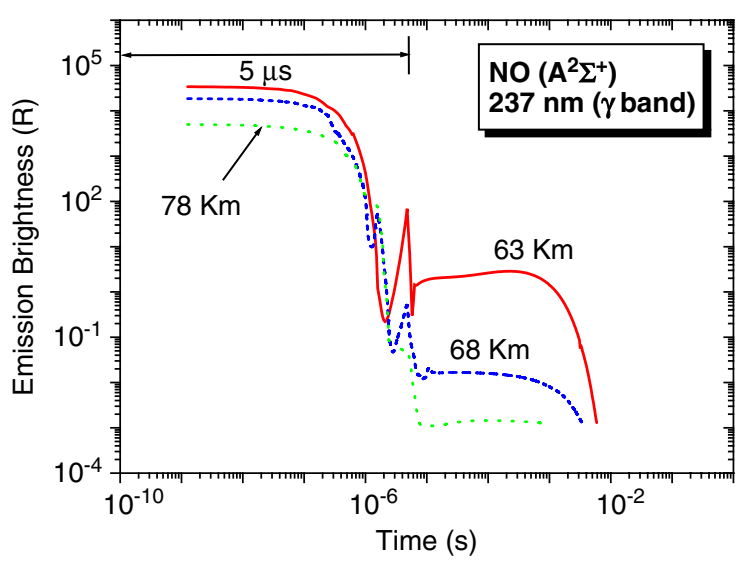

Figure 32. Time-dependent behaviour of the emission brightness of the NO- $\gamma$ band under the conditions of a single sprite event for three different altitudes. The lines indicate the same as in figure 1.

is predicted that the higher the altitude, the lower the emission brightness. Also, the associated transients are longer for higher altitudes (up to about $10 \mathrm{~ms}$ for $78 \mathrm{~km}$ ). The only considered production channel of $\mathrm{N}_{2}\left(a^{1} \Pi_{\mathrm{g}}\right)$ is

$$
\mathrm{P} 12: \mathrm{N}_{2}+\mathrm{e} \rightarrow \mathrm{N}_{2}\left(a^{1} \Pi_{\mathrm{g}}\right)+\mathrm{e},
$$

while the loss of $\mathrm{N}_{2}\left(a^{1} \Pi_{\mathrm{g}}\right)$ is mainly due to collisional de-excitation (quenching) and radiative decay processes such as:

$$
\begin{aligned}
& \text { P182: } \mathrm{N}_{2}\left(a^{1} \Pi_{\mathrm{g}}\right)+\mathrm{O}_{2} \rightarrow \mathrm{N}_{2}+2 \mathrm{O}, \\
& \text { P183: } \mathrm{N}_{2}\left(a^{1} \Pi_{\mathrm{g}}\right)+\mathrm{N}_{2} \rightarrow \mathrm{N}_{2}+\mathrm{N}_{2}, \\
& \text { P486: } \mathrm{N}_{2}\left(a^{1} \Pi_{\mathrm{g}}\left(v^{\prime}=0\right)\right) \rightarrow \mathrm{N}_{2}\left(X^{1} \Sigma_{\mathrm{g}}^{+}\left(v^{\prime \prime}=2\right)\right)+h v_{11} .
\end{aligned}
$$

The above removal processes are followed by much weaker quenching reactions of $\mathrm{N}_{2}\left(a^{1} \Pi_{\mathrm{g}}\right)$ by $\mathrm{H}_{2} \mathrm{O}$ and NO:

$$
\begin{aligned}
& \mathrm{P} 427: \mathrm{N}_{2}\left(a^{1} \Pi_{\mathrm{g}}\right)+\mathrm{H}_{2} \mathrm{O} \rightarrow \mathrm{N}_{2}+\mathrm{H}+\mathrm{OH}, \\
& \mathrm{P} 184: \mathrm{N}_{2}\left(a^{1} \Pi_{\mathrm{g}}\right)+\mathrm{NO} \rightarrow \mathrm{N}_{2}+\mathrm{N}+\mathrm{O},
\end{aligned}
$$

and by the ionization process:

$$
\text { P181: } \mathrm{N}_{2}\left(a^{1} \Pi_{\mathrm{g}}\right)+\mathrm{N}_{2}\left(a^{1} \Pi_{\mathrm{g}}\right) \rightarrow \mathrm{N}_{2}+\mathrm{N}_{2}^{+}+\mathrm{e} .
$$

The LBH emission brightness shown in figure 4(b) of [47] corresponding to a sprite streamer taking place at an altitude of $70 \mathrm{~km}$, a time $=95 \mu$ s and within a strong field $\left(\sim E_{k}\right.$, where $E_{k}$ is the atmosphere breakdown field) is in reasonable agreement with the value ( $\sim 1 \mathrm{MR})$ of the $68 \mathrm{~km} \mathrm{LBH}$ emission brightness shown in figure 31 of this paper.

In addition to the LBH emissions from sprites, another possibly important UV emission that could play a distinct role in identifying the sprite chemical activity in the Earth mesosphere is that associated with the radiative decay (the so-called NO- $\gamma$ band emissions) of the electronically excited NO $\left(A^{2} \Sigma^{+}\right)$towards its ground electronic state $\mathrm{NO}\left(X^{2} \Pi_{\mathrm{r}}\right)$. We have represented in figure 32 the predicted $\mathrm{NO}-\gamma$ band emission brightness associated with a single sprite even taking place at three different altitudes $(63,68$ and $78 \mathrm{~km})$. We can see that the initial background values between the lowest altitude $(63 \mathrm{~km})$ and the highest one $(78 \mathrm{~km})$ are hardly one order of magnitude. The NO- $\gamma$ band emissions together with the possible excitation mechanisms of NO $\left(A^{2} \Sigma^{+}\right)$have been studied in detail in a number of papers (see, for instance, [96, 121-124]). However, because of the complexity of the air plasma (and/or $\mathrm{N}_{2}-\mathrm{O}_{2}$ with $\mathrm{NO}$ additions) discharges, most of the experimental studies on the kinetics of these plasmas have been performed under afterglow conditions in pulsed radiofrequency (RF) and positive corona discharges [121-124]. In particular, an original and remarkable observation reported in 1996 [121] mentioned that, in afterglow conditions, electron-impact excitation of $\mathrm{NO}\left(A^{2} \Sigma^{+}\right)$from its ground state $\mathrm{NO}\left(X^{2} \Pi_{\mathrm{r}}\right)\left(\mathrm{P} 35: \mathrm{NO}+\mathrm{e} \rightarrow \mathrm{NO}\left(A^{2} \Sigma^{+}\right)+\mathrm{e}\right)$ was negligible when compared with the resonant energy transfer process $\mathrm{P} 239: \mathrm{N}_{2}\left(A^{3} \Sigma_{\mathrm{u}}^{+}\right)+\mathrm{NO} \rightarrow \mathrm{N}_{2}+\mathrm{NO}\left(A^{2} \Sigma^{+}\right)$.

In spite of the above studies, little has been investigated about the plasma kinetics underlying the NO$-\gamma$ band emissions in sprite conditions. The latter are, in general, quite different from the controlled laboratory environments where previous experiments have been carried out. To our knowledge, there is only one recent work published in 2007 where the NO- $\gamma$ band emissions from sprites have been modelled [48]. However, this model is based on a relatively simple kinetic scheme and makes some assumptions in connection with dominant microscopic processes that, although proved to be true in laboratory environments, are not necessarily completely right in sprite air plasma environments. For instance, in the chemical model presented in [48], it is assumed (based on [124]) that the direct electron-impact excitation of $\operatorname{NO}\left(A^{2} \Sigma^{+}\right)$from its ground state is negligible in comparison with the resonant energy transfer process P239 mentioned above. The latter is only partially right according to the findings of this work. The main reason sustaining this has its roots in the fact that the electron distribution function in the transitory sprite air plasma is non-Maxwellian (see figure 3(a)). The latter has, while the pulse is on, a tremendous impact on the relative importance of the electron rate coefficients and, consequently, on the relative importance of different kinetics channels. In this regard, the model presented in [48] assumes the rate coefficient calculated in [124] for the direct electron-impact excitation of $\operatorname{NO}\left(A^{2} \Sigma^{+}\right)$ from $\operatorname{NO}\left(X^{2} \Pi_{\mathrm{r}}\right)$. However, in [124] this rate is obtained by assuming a Maxwellian electron distribution function. The latter assumption is understandable since it considerably simplifies the problem but it is far from being realistic in sprite plasma environments. The value obtained in [124] (see figure 9 in [124]) for the electron-impact excitation of $\mathrm{NO}\left(A^{2} \Sigma^{+}\right)$for $T_{\mathrm{e}}^{\max } \sim 5 \mathrm{eV}$ (or mean energy of $\sim 7.5 \mathrm{eV}$ ) is $k^{\max } \sim 10^{-10} \mathrm{~cm}^{3} \mathrm{~s}^{-1}$. The latter value is derived without specifying its range of validity, that is, whether it applies to conditions when the pulsed discharge is on or after it is over (afterglow). In our case, we have found that during the discharge (electric pulse on, time $\leqslant 5 \mu \mathrm{s}$ ), the mean electron energy is $7.86 \mathrm{eV}$ and the corresponding non-Maxwellian rate coefficient for the direct electron-impact excitation of $\mathrm{NO}\left(A^{2} \Sigma^{+}\right)$from $\mathrm{NO}\left(X^{2} \Pi_{\mathrm{r}}\right)$ is $k^{\text {No-Max }} \sim 10^{-8} \mathrm{~cm}^{3} \mathrm{~s}^{-1}$, that is, it is two orders of magnitude higher than that calculated in [124] and later on used in [48]. After the pulse (time $>$ $5 \mu \mathrm{s}$ ), we have obtained that $k^{\text {No-Max }} \sim 2 \times 10^{-18} \mathrm{~cm}^{3} \mathrm{~s}^{-1}$, that is, considerably lower than the $k^{\text {No-Max }} \sim 10^{-8} \mathrm{~cm}^{3} \mathrm{~s}^{-1}$ 
valid while the pulse is acting. The consequences of all this is that before the end of the pulse (time $\leqslant 5 \mu \mathrm{s}$ ), the dominant production reaction of $\mathrm{NO}\left(A^{2} \Sigma^{+}\right)$is

$$
\mathrm{P} 35: \mathrm{NO}\left(X^{2} \Pi_{\mathrm{r}}\right)+\mathrm{e} \rightarrow \mathrm{NO}\left(A^{2} \Sigma^{+}\right)+\mathrm{e},
$$

followed by the resonant energy transfer process (with a rate coefficient of two orders of magnitude lower than that of P35):

$$
\text { P239: } \mathrm{N}_{2}\left(A^{3} \Sigma_{\mathrm{u}}^{+}\right)+\mathrm{NO} \rightarrow \mathrm{N}_{2}+\mathrm{NO}\left(A^{2} \Sigma^{+}\right) .
$$

The losses of $\operatorname{NO}\left(A^{2} \Sigma^{+}\right)$before the electric pulse is off (time $\leqslant 5 \mu \mathrm{s}$ ) are mainly due to its radiative decay:

$\mathrm{P} 479: \mathrm{NO}\left(A^{2} \Sigma^{+}\left(v^{\prime}=0\right)\right) \rightarrow \mathrm{NO}\left(X^{2} \Pi_{\mathrm{r}}\left(v^{\prime \prime}=0\right)\right)+h v_{4}$,

followed by the less important quenching of $\mathrm{NO}\left(A^{2} \Sigma^{+}\right)$by $\mathrm{O}_{2}$ :

$$
\mathrm{P} 240: \mathrm{NO}\left(A^{2} \Sigma^{+}\right)+\mathrm{O}_{2} \rightarrow \mathrm{NO}\left(X^{2} \Pi_{\mathrm{r}}\right)+\mathrm{O}_{2},
$$

and by the even less noticeable quenching of $\operatorname{NO}\left(A^{2} \Sigma^{+}\right)$ by $\mathrm{N}_{2}$ :

$$
\mathrm{P} 241: \mathrm{NO}\left(A^{2} \Sigma^{+}\right)+\mathrm{N}_{2} \rightarrow \mathrm{NO}\left(X^{2} \Pi_{\mathrm{r}}\right)+\mathrm{N}_{2}\left(A^{3} \Sigma_{\mathrm{u}}^{+}\right) .
$$

Right after the pulse (time $>5 \mu \mathrm{s}$ ), the resonant energy transfer process P239 becomes the dominant production reaction of $\mathrm{NO}\left(A^{2} \Sigma^{+}\right)$while the electron-impact excitation of $\operatorname{NO}\left(A^{2} \Sigma^{+}\right)$becomes negligible (with the rate coefficients many orders of magnitude smaller than that of P239). The losses at this time remain controlled by the radiative de-excitation P479 followed by the less important quenching reactions $\mathrm{P} 240$ and $\mathrm{P} 241$.

We see in figure 32 that the emission brightness associated with $\mathrm{NO}\left(A^{2} \Sigma^{+}\right)$radiative decay goes down very quickly from $\sim 5 \times 10^{3} \mathrm{R}$ (at $78 \mathrm{~km}$ ) and $\sim 5 \times 10^{3} \mathrm{R}$ (at $63 \mathrm{~km}$ ) to less than $\sim 10^{-1} \mathrm{R}$ at about $1 \mathrm{~ms}$ (for 78 and $68 \mathrm{~km}$ ) and $\sim 10^{1} \mathrm{R}$ (for $63 \mathrm{~km}$ ). If we compare the LBH emission brightness (shown in figure 31) with that of the NO- $\gamma$ band (presented in figure 32), it can be clearly seen that the LBH brightness is considerably higher than that of the NO- $\gamma$ band in the sprite streamer head discussed here.

3.7.2. Infrared emissions. To finish this section, we show in figures 33-36 the different IR emissions as predicted by the present sprite kinetic model due to the radiative decay of the previously excited $\mathrm{CO}_{2}$ molecules due to sprite chemical activity in the mesosphere. To the author's knowledge, only two previous works published a decade ago [44,45] have partially investigated the possible existence of IR emissions from sprite streamers that could be seen from the outer space. The emission brightness associated with the radiative transition of the wavelength $4.26 \mu \mathrm{m}$ from the vibrationally excited $\mathrm{CO}_{2}\left(\begin{array}{ll}0 & 0\end{array}\right)$ is shown in figure 33. It can be seen that, right at the end of the electric pulse at 63 and $68 \mathrm{~km}$, the $4.26 \mu \mathrm{m}$ emission brightness exhibits an abrupt increase that is much smoother at $78 \mathrm{~km}$. However, the maximum values are reached (for the three altitudes) well after the pulse is over since it is found at $\sim 1 \mathrm{~ms}(63 \mathrm{~km})$ and $\sim 10 \mathrm{~ms}(68$ and $78 \mathrm{~km})$. It is also worth mentioning that the $4.26 \mu \mathrm{m}$ emission brightness shows a considerable increase above its background levels. The latter enhancements range, as seen in figure 33 , between

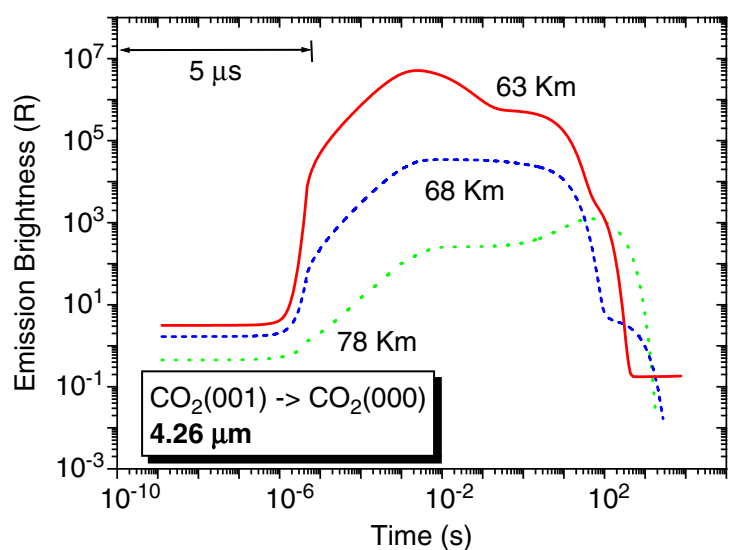

Figure 33. Time-dependent behaviour of the emission brightness of $\mathrm{CO}_{2}\left(\begin{array}{ll}0 & 0\end{array}\right)-4.26 \mu \mathrm{m}$ under the conditions of a single sprite event for three different altitudes. The lines indicate the same as in figure 1 .

about three orders of magnitude (at $78 \mathrm{~km}$ ) and more than six orders of magnitude (for $63 \mathrm{~km}$ ). Another interesting feature is that the transients last for quite a long time with a relatively high brightness of above $10^{5} \mathrm{R}$ for up to $10 \mathrm{~ms}$ (at $63 \mathrm{~km}$ ), above $10^{5} \mathrm{R}$ up to $10 \mathrm{~s}$ (at $63 \mathrm{~km}$ ) and above $10^{4} \mathrm{R}$ up to $10 \mathrm{~ms}$ (at $68 \mathrm{~km}$ ).

Before the pulse is off (time $\leqslant 5 \mu \mathrm{s}$ ), the production of $\mathrm{CO}_{2}\left(\begin{array}{ll}0 & 0\end{array}\right)$ is driven by direct electron-impact vibrational excitation and by near-resonant exchange of vibrational energy between $\mathrm{N}_{2}$ and $\mathrm{CO}_{2}$ :

$$
\mathrm{P} 44: \mathrm{CO}_{2}+\mathrm{e} \leftrightarrow \mathrm{CO}_{2}\left(\begin{array}{lll}
0 & 0 & 1
\end{array}\right)+\mathrm{e},
$$

followed by the vibrational-vibrational process that transfers the energy stored in the previously electronically excited $\mathrm{N}_{2}\left(v_{1}\right)$ to $\mathrm{CO}_{2}$ :

$$
\text { P156: } \mathrm{N}_{2}\left(v_{1}\right)+\mathrm{CO}_{2} \rightarrow \mathrm{CO}_{2}(001)+\mathrm{N}_{2} \text {. }
$$

The losses of $\mathrm{CO}_{2}(001)$, at 63 and $68 \mathrm{~km}$, before the pulse is off (time $\leqslant 5 \mu \mathrm{s}$ ) are due to

$$
\text { P157: } \mathrm{N}_{2}+\mathrm{CO}_{2}\left(\begin{array}{lll}
0 & 0 & 1
\end{array}\right) \rightarrow \mathrm{CO}_{2}+\mathrm{N}_{2}\left(v_{1}\right),
$$

closely followed by

$$
\mathrm{P} 481: \mathrm{CO}_{2}(001) \rightarrow \mathrm{CO}_{2}+h \nu_{6}(4.26 \mu \mathrm{m})
$$

and the much weaker radiative decay $\mathrm{P} 480: \mathrm{CO}_{2}\left(\begin{array}{ll}0 & 01)\end{array} \rightarrow\right.$ $\mathrm{CO}_{2}(100)+h v_{5}$ leading to the $9.4 \mu \mathrm{m}$ IR emission from $\mathrm{CO}_{2}(001)$. At $78 \mathrm{~km}$ high, the process $\mathrm{P} 481$ becomes more important than P157.

After the pulse (time $>5 \mu \mathrm{s}), \mathrm{CO}_{2}(001)$ is mainly produced by the process $\mathrm{P} 156$, that is, by near-resonant exchange of vibrational energy between $\mathrm{N}_{2}$ and $\mathrm{CO}_{2}$ that is much more important than the direct electron-impact excitation of $\mathrm{CO}_{2}(001)$ (process $\mathrm{P} 44$ ) at 63 and $68 \mathrm{~km}$ but not at $78 \mathrm{~km}$. When the pulse is over, the loss mechanisms of $\mathrm{CO}_{2}\left(\begin{array}{lll}0 & 0 & 1\end{array}\right)$ are the same as described above for time $\leqslant 5 \mu \mathrm{s}$.

The emission brightness due to the radiative decay of $\mathrm{CO}_{2}\left(\begin{array}{ll}0 & 0\end{array}\right)$ towards $\mathrm{CO}_{2}\left(\begin{array}{ll}10 & 0\end{array}\right)$ emitting light of $9.4 \mu \mathrm{m}$ is shown in figure 34 , where we can see that its value is much smaller than the brightness of the $4.26 \mu \mathrm{m}$ transition.

The emission brightness associated to the $13.9 \mu \mathrm{m}$ radiative transition between $\mathrm{CO}_{2}(100)$ and $\mathrm{CO}_{2}(010)$ is 


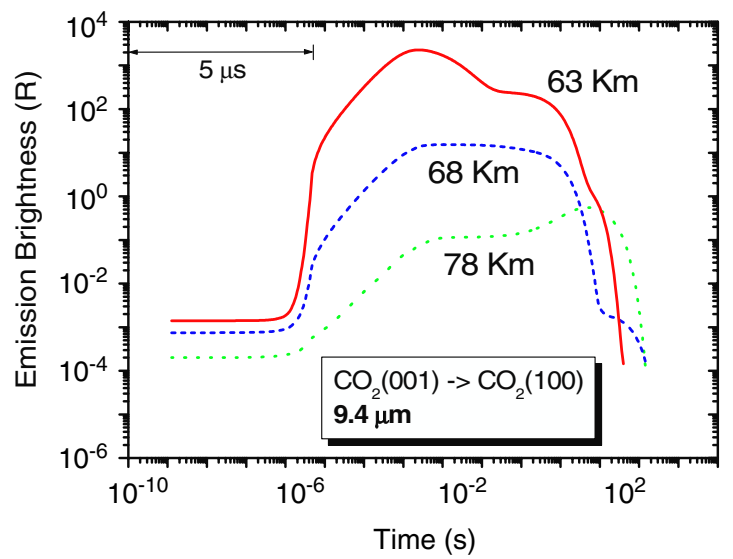

Figure 34. Time-dependent behaviour of the emission brightness of $\mathrm{CO}_{2}\left(\begin{array}{ll}0 & 0\end{array}\right)-9.4 \mu \mathrm{m}$ under the conditions of a single sprite event for three different altitudes. The lines indicate the same as in figure 1 .

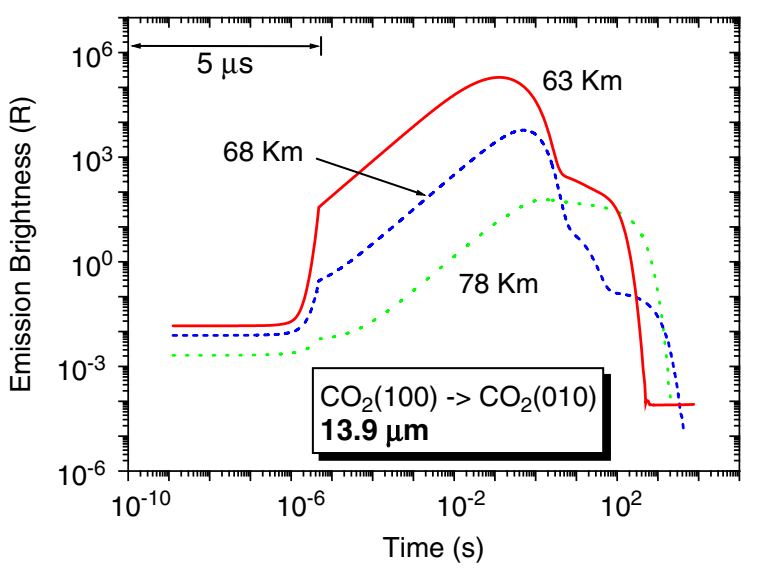

Figure 35. Time-dependent behaviour of the emission brightness

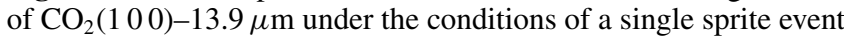
for three different altitudes. The lines indicate the same as in figure 1.

shown in figure 35 where we can see that its maximum values of about $10^{6} \mathrm{R}, 10^{4} \mathrm{R}$ and $10^{2} \mathrm{R}$ are reached at $\sim 100 \mathrm{~ms}(63 \mathrm{~km})$, $500 \mathrm{~ms}(68 \mathrm{~km})$ and $1 \mathrm{~s}(78 \mathrm{~km})$, respectively. Before the pulse is off (time $\leqslant 5 \mu \mathrm{s}$ ), the production of $\mathrm{CO}_{2}(100)$ is controlled by:

$$
\mathrm{P} 43: \mathrm{CO}_{2}+\mathrm{e} \leftrightarrow \mathrm{CO}_{2}\left(\begin{array}{lll}
1 & 0 & 0
\end{array}\right)+\mathrm{e},
$$

followed by the less important

$$
\mathrm{P} 480: \mathrm{CO}_{2}\left(\begin{array}{lll}
0 & 0 & 1
\end{array}\right) \rightarrow \mathrm{CO}_{2}(100)+h v_{5}(9.4 \mu \mathrm{m}),
$$

while the removal of $\mathrm{CO}_{2}(100)$ is due to its radiative decay:

$$
\mathrm{P} 482: \mathrm{CO}_{2}(100) \rightarrow \mathrm{CO}_{2}(010)+h \nu_{7}(13.9 \mu \mathrm{m}) .
$$

After the pulse (time $>5 \mu \mathrm{s}), \mathrm{CO}_{2}(100)$ is mainly produced at 63 and $68 \mathrm{~km}$ by process $\mathrm{P} 480$ followed by $\mathrm{P} 43$. At $78 \mathrm{~km}$, $\mathrm{P} 43$ comes first followed by $\mathrm{P} 480$. The loss of $\mathrm{CO}_{2}(100)$ is still dominated by $\mathrm{P} 482$ after the pulse is off.

Finally, figure 36 shows the time-dependent behaviour of the emission brightness related to the $14.9 \mu \mathrm{m}$ transition. For the three altitudes evaluated, its maximum is found around $1 \mathrm{~s}$, that is, quite after the electric pulse has finished. The main

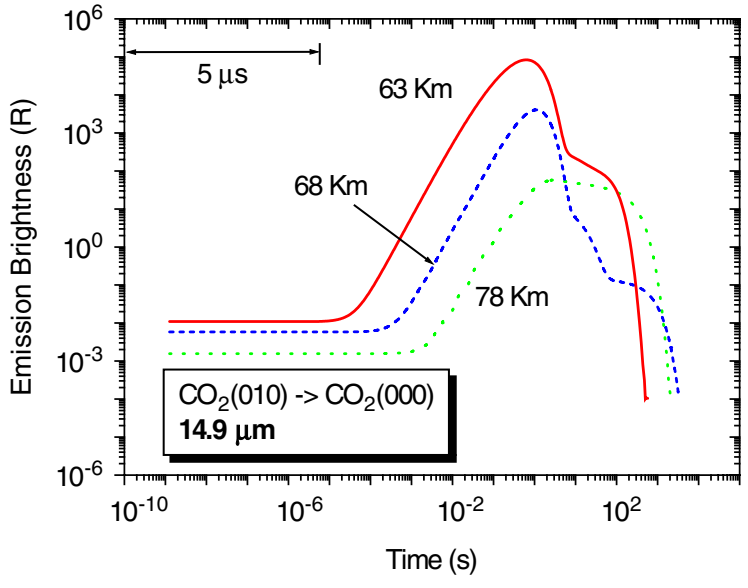

Figure 36. Time-dependent behaviour of the emission brightness of $\mathrm{CO}_{2}(010)-14.9 \mu \mathrm{m}$ under the conditions of a single sprite event for three different altitudes. The lines indicate the same as in figure 1.

channel contributing to the production of $\mathrm{CO}_{2}\left(\begin{array}{ll}0 & 10) \\ 0 & \text { before }\end{array}\right.$ the pulse is over (time $\leqslant 5 \mu \mathrm{s}$ ) is

$\mathrm{P} 482: \mathrm{CO}_{2}(100) \rightarrow \mathrm{CO}_{2}(010)+h \nu_{7}(13.9 \mu \mathrm{m})$,

followed by the almost negligible direct electron-impact excitation:

$$
\mathrm{P} 42: \mathrm{CO}_{2}+\mathrm{e} \leftrightarrow \mathrm{CO}_{2}(010)+\mathrm{e},
$$

while $\mathrm{CO}_{2}\left(\begin{array}{lll}0 & 1 & 0\end{array}\right)$ is mainly lost due to its radiative decay:

$\mathrm{P} 483: \mathrm{CO}_{2}(010) \rightarrow \mathrm{CO}_{2}+h v_{8}(14.9 \mu \mathrm{m})$.

After the pulse (time $>5 \mu \mathrm{s}$ ), the $\mathrm{CO}_{2}(010)$ emission brightness keeps growing up to about $1 \mathrm{~s}$ when the losses due to $\mathrm{P} 483$ become dominant and produce its decline and further disappearance at about $10 \mathrm{~s}$.

The emission brightness associated with the $4.26 \mu \mathrm{m}$ is clearly the strongest out of the four IR $\mathrm{CO}_{2}$ transitions considered here since its spontaneous emission coefficient is also the highest one $\left(450 \mathrm{~s}^{-1}\right)$. The predicted brightness for the $4.26 \mu \mathrm{m}$ emission leads one to think that, perhaps, it could be observed from outer space.

\section{Conclusions}

In this paper we have tried to evaluate the local chemical impact of single sprite events on the Earth mesosphere at three different altitudes $(63,68$ and $78 \mathrm{~km})$. In order to do this, we have developed a full kinetic approach including the coupling of the rate equations for the different atmospheric components considered to a Boltzmann transport equation. The latter has allowed us to self-consistently evaluate the electron distribuction function of the transient non-equilibrium air plasma formed following the passage of a fast electric pulse through the mesosphere. Although the model presented is just an approximation to this complex problem, we have been able to get some insights in connection with the expected enhancements of important species such as, for instance, nitride oxides, ozone and/or negative ions. At $68 \mathrm{~km}$, the concentrations of $\mathrm{NO}$ and $\mathrm{NO}_{2}$ increase by about one order of 
magnitude while that of $\mathrm{NO}_{3}$ exhibits an important growth of up to almost three orders of magnitude. However, the variation of the $\mathrm{O}_{3}$ density predicted by the model in the sprite streamer head is negligible in all the altitudes investigated. The impact of humidity has also been evaluated by explicitly incorporating $\mathrm{H} / \mathrm{OH}$ containing chemical reactions. According to our findings, the presence of $4 \mathrm{ppm}$ of $\mathrm{H}_{2} \mathrm{O}$ hardly affects the concentrations of the species evaluated. The only detectable effect was that in $\mathrm{O}_{3}^{-}$at 68 and $78 \mathrm{~km}$ and, especially, in $\mathrm{CO}_{4}^{-}$though its number density is very small. The present model predicts that the electron density can go up to $10^{4} \mathrm{~cm}^{-3}$ (at $68 \mathrm{~km}$ ) and up to more than $10^{6} \mathrm{~cm}^{-3}$ (at $63 \mathrm{~km}$ ). The latter values, together with the calculation of the electron mobilities, allowed us to estimate the impact of a single sprite event on the electron component of the electrical conductivity of air between 63 and $78 \mathrm{~km}$. We found that the predicted electrical conductivities can reach values of up to $10^{-7} \mho \mathrm{cm}^{-1}$ (at $68 \mathrm{~km}$ ), that is, an enhancement of four orders of magnitude is predicted over its background mid-latitude and nighttime value at $70 \mathrm{~km}$. The total power delivered by the streamer head of a single sprite event is also estimated and it results in values that go from $1677 \mathrm{~W}$ (at $78 \mathrm{~km}$ ) to $78 \mathrm{MW}$ (at $63 \mathrm{~km}$ ). The analysis of the temporal evolution of the electron distribution function during and after the pulse indicates that its departure from a Maxwellian EDF is important.

Finally, we studied the emission brightness of several important radiative transitions associated with sprites in the visible, IR and UV regions of the electromagnetic spectrum. We found that, in general, the LBH emission brightness is always higher than that from the NO- $\gamma$ band system. The evaluation of four different emissions (4.26, 9.4, 13.9 and $14.9 \mu \mathrm{m}$ ) from vibrationally excited $\mathrm{CO}_{2}$ molecules shows that all of them exhibit noticeable enhancements, although the one associated with $4.26 \mu \mathrm{m}$ is the most important since it reaches $1 \mathrm{MR}$ at $63 \mathrm{~km}$ and almost $100 \mathrm{MR}$ at $68 \mathrm{~km}$. The latter could be seen from space with appropriate equipment.

\section{Acknowledgments}

The author acknowledges enriching discussions with Dave Sentman, Torsten Neubert, Victor Pasko, Oliver Chanrion, Vasco Guerra, Carl-Fredrik Enell, Gennady Milikh, Robert Roussel-Dupre, Anne Bourdon and Cheng-Ling Kuo. He would like to thank Manuel López-Puertas (IAA-CSIC) for providing WACCM3 initial data values of atmospheric chemical components. Partial financial support was provided by CSIC under Grant No 2006HU0002 and by MEC under Project Nos MAT2006-13006-C02-01 and ENE2006-14577C04-03. The author also wishes to thank the guest editors (Ute Ebert and Dave Sentman) of this special cluster issue for organizing such a stimulating conference in Leiden, last autumn 2007, and the Lorentz Center for the support offered.

\section{Appendix A.}

Initial values of atmospheric species with concentrations (in $\left.\mathrm{cm}^{-3}\right)$ different from zero at $38^{\circ}$ latitude $\left(0^{\circ}\right.$ longitude $)$ during midnight conditions and for three values of altitudes: 63, 68 and $78 \mathrm{~km}$. The relative concentrations of the background atmospheric components were the same for the three heights considered: $\mathrm{N}_{2}(78.08 \%), \mathrm{O}_{2}$ (20.94\%), $\mathrm{Ar}$ $(0.094 \%), \mathrm{CO}_{2}(35 \mathrm{ppm})$ and $\mathrm{H}_{2} \mathrm{O}(4 \mathrm{ppm})$. These initial values are obtained from the latest version (v3) of the Whole Atmosphere Community Climate Model (WACCM) based on the National Center for Atmospheric Research's Community Atmospheric Model (CAM). The background pressures and gas temperatures used for the different altitudes investigated are 0.068 Torr $\left(T_{\mathrm{g}}=238 \mathrm{~K}\right), 0.034$ Torr $\left(T_{\mathrm{g}}=220 \mathrm{~K}\right)$ and 0.0083 Torr $\left(T_{\mathrm{g}}=200 \mathrm{~K}\right)$ for $63 \mathrm{~km}, 68 \mathrm{~km}$ and $78 \mathrm{~km}$, respectively.

\begin{tabular}{llll}
\hline Species & $h=63 \mathrm{~km}$ & $h=68 \mathrm{~km}$ & $h=78 \mathrm{~km}$ \\
\hline$N_{\mathrm{e}}$ & $3.000 \times 10^{1}$ & $5.000 \times 10^{1}$ & $7.000 \times 10^{1}$ \\
$\mathrm{O}_{2}^{+}$ & $3.000 \times 10^{1}$ & $5.000 \times 10^{1}$ & $7.000 \times 10^{1}$ \\
$\mathrm{O}$ & $4.448 \times 10^{0}$ & $5.215 \times 10^{3}$ & $5.330 \times 10^{8}$ \\
$\mathrm{O}_{3}$ & $4.555 \times 10^{9}$ & $2.116 \times 10^{9}$ & $5.199 \times 10^{7}$ \\
$\mathrm{~N}$ & 0 & $3.481 \times 10^{0}$ & $8.222 \times 10^{2}$ \\
$\mathrm{NO}$ & $1.344 \times 10^{6}$ & $9.719 \times 10^{5}$ & $4.648 \times 10^{3}$ \\
$\mathrm{NO}_{2}$ & $2.038 \times 10^{6}$ & $4.864 \times 10^{5}$ & $3.447 \times 10^{4}$ \\
$\mathrm{NO}_{3}$ & $3.219 \times 10^{2}$ & $1.759 \times 10^{1}$ & 0 \\
$\mathrm{~N}_{2} \mathrm{O}$ & $2.619 \times 10^{5}$ & $9.623 \times 10^{4}$ & $7.746 \times 10^{3}$ \\
$\mathrm{H}$ & $3.502 \times 10^{1}$ & $1.950 \times 10^{2}$ & $2.077 \times 10^{7}$ \\
$\mathrm{OH}$ & $5.135 \times 10^{4}$ & $6.990 \times 10^{4}$ & $4.611 \times 10^{6}$ \\
$\mathrm{H}_{2}$ & $2.707 \times 10^{9}$ & $2.673 \times 10^{9}$ & $1.662 \times 10^{9}$ \\
$\mathrm{HO}_{2}$ & $9.513 \times 10^{5}$ & $7.331 \times 10^{5}$ & $1.820 \times 10^{6}$ \\
$\mathrm{H}_{2} \mathrm{O}_{2}$ & $2.688 \times 10^{5}$ & $2.563 \times 10^{5}$ & $1.941 \times 10^{3}$ \\
$\mathrm{HNO}_{3}$ & $6.112 \times 10^{1}$ & $6.711 \times 10^{0}$ & $2.874 \times 10^{0}$ \\
$\mathrm{CO}^{3}$ & $1.375 \times 10^{9}$ & $1.830 \times 10^{9}$ & $3.245 \times 10^{9}$ \\
$\mathrm{~N}_{2}$ & $2.137 \times 10^{15}$ & $1.165 \times 10^{15}$ & $3.129 \times 10^{14}$ \\
$\mathrm{O}_{2}$ & $5.731 \times 10^{14}$ & $3.126 \times 10^{14}$ & $8.395 \times 10^{13}$ \\
$\mathrm{Ar}^{13}$ & $2.585 \times 10^{13}$ & $1.410 \times 10^{13}$ & $3.786 \times 10^{12}$ \\
$\mathrm{CO}_{2}$ & $9.579 \times 10^{11}$ & $5.225 \times 10^{11}$ & $1.403 \times 10^{11}$ \\
$\mathrm{H}_{2} \mathrm{O}$ & $1.095 \times 10^{10}$ & $5.972 \times 10^{9}$ & $1.603 \times 10^{9}$ \\
\hline
\end{tabular}

\section{Appendix B.}

Reactions and rate coefficients associated with the electrondriven chemistry and heavy particle chemistry. The rate coefficients for the electron-impact processes are evaluated using the calculated electron distribution function (EDF) and the corresponding cross sections. When cross sections are not available, the rates of electronic processes are given as $k_{\mathrm{e}}=a \times T_{\mathrm{e}}^{b} \times \exp \left(-c / T_{\mathrm{e}}\right)$ where $T_{\mathrm{e}}$ (in $\mathrm{eV}$ ) is the 'electron temperature'. The rate coefficients of the heavy particle (neutrals and ions) reactions are parametrized as $k_{\mathrm{h}}=d \times$ $\left(T_{\mathrm{g}} / 300\right)^{e} \times \exp \left(-f / T_{\mathrm{g}}\right) T_{\mathrm{g}}$ (in $\mathrm{K}$ ) being the background gas temperature for which the rates are known. The units of $k_{\mathrm{e}, \mathrm{h}}$ are $\mathrm{cm}^{3} \mathrm{~s}^{-1}$ and $\mathrm{cm}^{6} \mathrm{~s}^{-1}$ for two- and three-body reactions, respectively. The reference source of the cross sections and/or rates used is indicated in the last column of each of the tables. 


\begin{tabular}{|c|c|c|c|c|c|}
\hline & Reaction & & ces & & \\
\hline$E D$ & ependent processes (1) & & & & \\
\hline 1 & $\mathrm{Ar}+\mathrm{e} \rightarrow \operatorname{Ar}\left({ }^{3} \mathrm{P}_{2}\right)+\mathrm{e}$ & & & & \\
\hline 2 & $\mathrm{Ar}+\mathrm{e} \rightarrow \mathrm{Ar}^{+}+2 \mathrm{e}$ & & & & \\
\hline 3 & $\mathrm{~N}_{2}+\mathrm{e} \leftrightarrow \mathrm{N}_{2}\left(v_{i}\right)+\mathrm{e} ;(i=1, \ldots 8)$ & & & & \\
\hline 4 & $\mathrm{~N}_{2}\left(v_{1}\right)+\mathrm{e} \leftrightarrow \mathrm{N}_{2}\left(v_{2}\right)+\mathrm{e}$ & & & & \\
\hline 5 & $\mathrm{~N}_{2}\left(v_{2}\right)+\mathrm{e} \leftrightarrow \mathrm{N}_{2}\left(v_{3}\right)+\mathrm{e}$ & & & & \\
\hline 6 & $\mathrm{~N}_{2}\left(v_{3}\right)+\mathrm{e} \leftrightarrow \mathrm{N}_{2}\left(v_{4}\right)+\mathrm{e}$ & & & & \\
\hline 7 & $\mathrm{~N}_{2}\left(v_{4}\right)+\mathrm{e} \leftrightarrow \mathrm{N}_{2}\left(v_{5}\right)+\mathrm{e}$ & & & & \\
\hline 8 & $\mathrm{~N}_{2}\left(v_{5}\right)+\mathrm{e} \leftrightarrow \mathrm{N}_{2}\left(v_{6}\right)+\mathrm{e}$ & & & & \\
\hline 9 & $\mathrm{~N}_{2}\left(v_{6}\right)+\mathrm{e} \leftrightarrow \mathrm{N}_{2}\left(v_{7}\right)+\mathrm{e}$ & & & & \\
\hline 10 & $\mathrm{~N}_{2}\left(v_{7}\right)+\mathrm{e} \leftrightarrow \mathrm{N}_{2}\left(v_{8}\right)+\mathrm{e}$ & & & & \\
\hline 11 & $\mathrm{~N}_{2}+\mathrm{e} \rightarrow \mathrm{N}_{2}\left(A^{3} \Sigma_{\mathrm{u}}^{+}\right)+\mathrm{e}$ & & & & \\
\hline 12 & $\mathrm{~N}_{2}+\mathrm{e} \rightarrow \mathrm{N}_{2}\left(a^{1} \Pi_{\mathrm{g}}\right)+\mathrm{e}$ & & & & \\
\hline 13 & $\mathrm{~N}_{2}+\mathrm{e} \rightarrow \mathrm{N}_{2}\left(a^{\prime 1} \Sigma_{\mathrm{u}}^{-}\right)+\mathrm{e}$ & & & & \\
\hline 14 & $\mathrm{~N}_{2}+\mathrm{e} \rightarrow \mathrm{N}_{2}\left(B^{3} \Pi_{\mathrm{g}}\right)+\mathrm{e}$ & & & & \\
\hline 15 & $\mathrm{~N}_{2}+\mathrm{e} \rightarrow \mathrm{N}_{2}\left(C^{3} \Pi_{\mathrm{u}}\right)+\mathrm{e}$ & & & & \\
\hline 16 & $\mathrm{~N}_{2}+\mathrm{e} \rightarrow \mathrm{N}_{2}^{+}+2 \mathrm{e}$ & & & & \\
\hline 17 & $\mathrm{~N}_{2}+\mathrm{e} \rightarrow \mathrm{N}_{2}^{+}\left(B^{2} \Sigma_{\mathrm{u}}^{+}\right)+2 \mathrm{e}$ & & & & \\
\hline 18 & $\mathrm{~N}_{2}+\mathrm{e} \rightarrow \mathrm{N}+\mathrm{N}+\mathrm{e}$ & & & & \\
\hline 19 & $\mathrm{~N}_{2}+\mathrm{e} \rightarrow \mathrm{N}+\mathrm{N}\left({ }^{2} \mathrm{D}\right)+\mathrm{e}$ & & & & \\
\hline 20 & $\mathrm{~N}_{2}+\mathrm{e} \rightarrow \mathrm{N}+\mathrm{N}\left({ }^{2} \mathrm{P}\right)+\mathrm{e}$ & & & & \\
\hline 21 & $\mathrm{O}_{2}+\mathrm{e} \rightarrow \mathrm{O}_{2}^{+}+2 \mathrm{e}$ & & & & \\
\hline 22 & $\mathrm{O}_{2}+\mathrm{e} \rightarrow \mathrm{O}_{2}\left(a^{1} \Delta_{\mathrm{g}}\right)+\mathrm{e}$ & & & & \\
\hline 23 & $\mathrm{O}_{2}+\mathrm{e} \rightarrow \mathrm{O}_{2}\left(b^{1} \Sigma_{\mathrm{g}}^{+}\right)+\mathrm{e}$ & & & & \\
\hline 24 & $\mathrm{O}_{2}+\mathrm{e} \rightarrow \mathrm{O}+\mathrm{O}+\mathrm{e}$ & & & & \\
\hline 25 & $\mathrm{O}_{2}+\mathrm{e} \rightarrow \mathrm{O}^{-}+\mathrm{O}$ & & & & \\
\hline 26 & $\mathrm{O}_{3}+\mathrm{e} \rightarrow \mathrm{O}^{-}+\mathrm{O}_{2}$ & & & & \\
\hline 27 & $\mathrm{O}_{3}+\mathrm{e} \rightarrow \mathrm{O}_{2}^{-}+\mathrm{O}$ & & & & \\
\hline 28 & $\mathrm{O}+\mathrm{e} \rightarrow \mathrm{O}^{+}+2 \mathrm{e}$ & & & & \\
\hline 29 & $\mathrm{O}+\mathrm{e} \rightarrow \mathrm{O}\left({ }^{1} \mathrm{D}\right)+\mathrm{e}$ & & & & \\
\hline 30 & $\mathrm{O}+\mathrm{e} \rightarrow \mathrm{O}\left({ }^{1} \mathrm{~S}\right)+\mathrm{e}$ & & & & \\
\hline 31 & $\mathrm{~N}_{2} \mathrm{O}+\mathrm{e} \rightarrow \mathrm{N}_{2}+\mathrm{O}^{-}$ & & & & \\
\hline 32 & $\mathrm{~N}_{2} \mathrm{O}+\mathrm{e} \rightarrow \mathrm{N}_{2} \mathrm{O}^{+}+2 \mathrm{e}$ & & & & \\
\hline 33 & $\mathrm{NO}+\mathrm{e} \rightarrow \mathrm{N}+\mathrm{O}^{-}$ & & & & \\
\hline 34 & $\mathrm{NO}+\mathrm{e} \rightarrow \mathrm{NO}^{+}+2 \mathrm{e}$ & & & & \\
\hline 35 & $\mathrm{NO}+\mathrm{e} \rightarrow \mathrm{NO}\left(A^{2} \Sigma^{+}\right)+\mathrm{e}$ & & & & \\
\hline$E D$ & ependent processes (2) & & & & \\
\hline 36 & $\mathrm{H}_{2} \mathrm{O}+\mathrm{e} \rightarrow \mathrm{H}+\mathrm{OH}+\mathrm{e}$ & & & & \\
\hline 37 & $\mathrm{H}_{2} \mathrm{O}+\mathrm{e} \rightarrow \mathrm{O}\left({ }^{1} \mathrm{D}\right)+\mathrm{H}_{2}+\mathrm{e}$ & & & & \\
\hline 38 & $\mathrm{H}_{2} \mathrm{O}+\mathrm{e} \rightarrow \mathrm{H}_{2} \mathrm{O}^{+}+2 \mathrm{e}$ & & & & \\
\hline 39 & $\mathrm{H}_{2} \mathrm{O}+\mathrm{e} \rightarrow \mathrm{OH}^{-}+\mathrm{H}$ & & & & \\
\hline 40 & $\mathrm{H}_{2} \mathrm{O}+\mathrm{e} \rightarrow \mathrm{H}^{-}+\mathrm{OH}$ & & & & \\
\hline 41 & $\mathrm{H}_{2} \mathrm{O}+\mathrm{e} \rightarrow \mathrm{H}_{2}+\mathrm{O}^{-}$ & & & & \\
\hline 42 & $\mathrm{CO}_{2}+\mathrm{e} \leftrightarrow \mathrm{CO}_{2}\left(\begin{array}{lll}0 & 1 & 0\end{array}\right)+\mathrm{e}$ & & & & \\
\hline 43 & $\mathrm{CO}_{2}+\mathrm{e} \leftrightarrow \mathrm{CO}_{2}\left(\begin{array}{lll}1 & 0 & 0\end{array}\right)+\mathrm{e}$ & & & & \\
\hline 44 & $\mathrm{CO}_{2}+\mathrm{e} \leftrightarrow \mathrm{CO}_{2}\left(\begin{array}{lll}0 & 0 & 1\end{array}\right)+\mathrm{e}$ & & & & \\
\hline 45 & $\mathrm{CO}_{2}+\mathrm{e} \rightarrow \mathrm{CO}+\mathrm{O}^{-}$ & & & & \\
\hline & Reaction & $a$ & $b$ & $c$ & References \\
\hline$T_{\mathrm{e}}-c$ & endent processes: ionization and di & ociative is & & & \\
\hline 46 & $\mathrm{e}+\mathrm{NO}_{2} \rightarrow \mathrm{NO}_{2}^{+}+2 \mathrm{e}$ & $2.6 \mathrm{E}-9$ & 0.5 & 10.0 & {$[80,81]$} \\
\hline 47 & $\mathrm{e}+\mathrm{NO} \rightarrow \mathrm{O}^{+}+\mathrm{N}+2 \mathrm{e}$ & $2.9 \mathrm{E}-9$ & 0.5 & 21.0 & {$[80,81]$} \\
\hline 48 & $\mathrm{e}+\mathrm{NO}_{2} \rightarrow \mathrm{NO}^{+}+\mathrm{O}+2 \mathrm{e}$ & $8.1 \mathrm{E}-9$ & 0.5 & 12.9 & {$[80,81]$} \\
\hline 49 & $\mathrm{e}+\mathrm{O}_{2} \rightarrow \mathrm{O}^{+}+\mathrm{O}+2 \mathrm{e}$ & $4.2 \mathrm{E}-9$ & 0.5 & 23.0 & {$[80,81]$} \\
\hline$T e-c$ & endent processes: dissociation & & & & \\
\hline 50 & $\mathrm{e}+\mathrm{O}_{3} \rightarrow \mathrm{O}_{2}+\mathrm{O}+\mathrm{e}$ & $1.0 \mathrm{E}-8$ & 0 & 0 & {$[82]$} \\
\hline 51 & $\mathrm{e}+\mathrm{NO} \rightarrow \mathrm{N}+\mathrm{O}+\mathrm{e}$ & $7.4 \mathrm{E}-9$ & 0 & 6.50 & {$[80,81]$} \\
\hline 52 & $\mathrm{e}+\mathrm{O}_{2} \rightarrow \mathrm{O}+\mathrm{O}\left({ }^{1} \mathrm{D}\right)+\mathrm{e}$ & $4.0 \mathrm{E}-8$ & 0 & 8.40 & {$[80,81]$} \\
\hline 53 & $\mathrm{e}+\mathrm{NO}_{2} \rightarrow \mathrm{NO}+\mathrm{O}+\mathrm{e}$ & $5.6 \mathrm{E}-9$ & 0 & 3.11 & {$[80,81]$} \\
\hline 54 & $\mathrm{e}+\mathrm{N}_{2} \mathrm{O} \rightarrow \mathrm{N}_{2}+\mathrm{O}+\mathrm{e}$ & $1.4 \mathrm{E}-9$ & 0 & 1.67 & {$[80,81]$} \\
\hline 55 & $\mathrm{e}+\mathrm{N}_{2} \mathrm{O} \rightarrow \mathrm{N}_{2}+\mathrm{O}\left({ }^{1} \mathrm{D}\right)+\mathrm{e}$ & $1.2 \mathrm{E}-9$ & 0 & 3.64 & {$[80,81]$} \\
\hline 56 & $\mathrm{e}+\mathrm{N}_{2} \mathrm{O} \rightarrow \mathrm{NO}+\mathrm{N}+\mathrm{e}$ & $1.0 \mathrm{E}-10$ & 0 & 4.93 & {$[80,81]$} \\
\hline$T e-c$ & endent processes: attachment & & & & \\
\hline & $\mathrm{e}+\mathrm{O}_{2}+\mathrm{O}_{2} \rightarrow \mathrm{O}_{2}^{-}+\mathrm{O}_{2}$ & $1.4 \mathrm{E}-29$ & & & {$[83]$} \\
\hline 58 & $\mathrm{e}+\mathrm{O}_{2}+\mathrm{N}_{2} \rightarrow \mathrm{O}_{2}^{-}+\mathrm{N}_{2}$ & $1.1 \mathrm{E}-31$ & & & [83] \\
\hline
\end{tabular}




\begin{tabular}{|c|c|c|c|c|c|c|}
\hline & Reaction & $a$ & $b$ & $c$ & References & \\
\hline 59 & $\mathrm{e}+\mathrm{O}+\mathrm{O}_{2} \rightarrow \mathrm{O}^{-}+\mathrm{O}_{2}$ & $1.0 \mathrm{E}-31$ & & & [69] & \\
\hline 60 & $\mathrm{e}+\mathrm{O}+\mathrm{N}_{2} \rightarrow \mathrm{O}^{-}+\mathrm{N}_{2}$ & $1.0 \mathrm{E}-31$ & & & [69] & \\
\hline 61 & $\mathrm{e}+\mathrm{NO}_{2} \rightarrow \mathrm{O}^{-}+\mathrm{NO}$ & $3.0 \mathrm{E}-11$ & & & {$[83]$} & \\
\hline 62 & $\mathrm{e}+\mathrm{NO}_{2} \rightarrow \mathrm{NO}_{2}^{-}$ & $1.0 \mathrm{E}-11$ & & & {$[83]$} & \\
\hline 63 & $\mathrm{e}+\mathrm{O}_{3}+\mathrm{O}_{2} \rightarrow \mathrm{O}_{3}^{-}+\mathrm{O}_{2}$ & $1.0 \mathrm{E}-31$ & & & [69] & \\
\hline 64 & $\mathrm{e}+\mathrm{NO}+\mathrm{N}_{2} \rightarrow \mathrm{NO}^{-}+\mathrm{N}_{2}$ & $1.0 \mathrm{E}-30$ & & & [83] & \\
\hline 65 & $\mathrm{e}+\mathrm{H}_{2} \mathrm{O}+\mathrm{O}_{2} \rightarrow \mathrm{O}_{2}^{-}+\mathrm{H}_{2} \mathrm{O}$ & $1.4 \mathrm{E}-29$ & & & {$[69]$} & \\
\hline \multicolumn{7}{|c|}{$T_{\mathrm{e}}$-dependent processes: recombination } \\
\hline 66 & $\mathrm{e}+\mathrm{N}_{2}^{+} \rightarrow \mathrm{N}+\mathrm{N}$ & $4.50 \mathrm{E}-8$ & -0.5 & & [83] & \\
\hline 67 & $\mathrm{e}+\mathrm{N}_{2}^{+} \rightarrow \mathrm{N}+\mathrm{N}\left({ }^{2} \mathrm{D}\right)$ & $3.21 \mathrm{E}-8$ & -0.5 & & {$[83]$} & \\
\hline 68 & $\mathrm{e}+\mathrm{N}_{2}^{+}+\mathrm{O}_{2} \rightarrow \mathrm{N}_{2}+\mathrm{O}_{2}$ & $2.49 \mathrm{E}-29$ & -1.5 & & {$[83]$} & \\
\hline 69 & $\mathrm{e}+\mathrm{O}_{2}^{+} \rightarrow \mathrm{O}+\mathrm{O}$ & $2.97 \mathrm{E}-9$ & -0.7 & & [84] & \\
\hline 70 & $\mathrm{e}+\mathrm{O}_{2}^{+} \rightarrow \mathrm{O}+\mathrm{O}\left({ }^{1} \mathrm{D}\right)$ & $8.67 E-9$ & -0.7 & & [84] & \\
\hline 71 & $\mathrm{e}+\mathrm{O}_{2}^{+} \rightarrow \mathrm{O}\left({ }^{1} \mathrm{D}\right)+\mathrm{O}\left({ }^{1} \mathrm{D}\right)$ & $6.87 \mathrm{E}-9$ & -0.7 & & {$[84]$} & \\
\hline 72 & $\mathrm{e}+\mathrm{NO}^{+} \rightarrow \mathrm{N}+\mathrm{O}$ & $1.66 \mathrm{E}-9$ & -1.5 & & [83] & \\
\hline 73 & $\mathrm{e}+\mathrm{NO}^{+} \rightarrow \mathrm{N}\left({ }^{2} \mathrm{D}\right)+\mathrm{O}$ & $7.76 \mathrm{E}-9$ & -1.0 & & [83] & \\
\hline 74 & $\mathrm{e}+\mathrm{NO}^{+}+\mathrm{O}_{2} \rightarrow \mathrm{NO}+\mathrm{O}_{2}$ & $2.49 \mathrm{E}-29$ & -1.5 & & [83] & \\
\hline 75 & $\mathrm{e}+\mathrm{NO}^{+}+\mathrm{N}_{2} \rightarrow \mathrm{NO}+\mathrm{N}_{2}$ & $2.49 \mathrm{E}-29$ & -1.5 & & [83] & \\
\hline 76 & $\mathrm{e}+\mathrm{O}_{2}^{+}+\mathrm{O}_{2} \rightarrow \mathrm{O}_{2}+\mathrm{O}_{2}$ & $2.49 \mathrm{E}-29$ & -1.5 & & [83] & \\
\hline 77 & $\mathrm{e}+\mathrm{N}_{4}^{+} \rightarrow \mathrm{N}_{2}+\mathrm{N}+\mathrm{N}$ & $3.13 \mathrm{E}-7$ & -0.41 & & [85] & \\
\hline 78 & $\mathrm{e}+\mathrm{N}_{4}^{+} \rightarrow \mathrm{N}_{2}^{+}+\mathrm{N}_{2}$ & $3.21 \mathrm{E}-7$ & -0.5 & & {$[83]$} & \\
\hline 79 & $\mathrm{e}+\mathrm{O}_{4}^{+} \rightarrow \mathrm{O}_{2}+\mathrm{O}+\mathrm{O}$ & $2.30 \mathrm{E}-6$ & & & [86] & \\
\hline 80 & $\mathrm{e}+\mathrm{O}_{4}^{+} \rightarrow \mathrm{O}_{2}+\mathrm{O}_{2}$ & $2.25 \mathrm{E}-7$ & -0.5 & & [83] & \\
\hline 81 & $\mathrm{e}+\mathrm{O}^{+}+\mathrm{e} \rightarrow \mathrm{O}+\mathrm{e}$ & $7.18 \mathrm{E}-25$ & -4.5 & & [83] & \\
\hline 82 & $\mathrm{e}+\mathrm{O}^{+}+\mathrm{N}_{2} \rightarrow \mathrm{O}+\mathrm{N}_{2}$ & $2.49 \mathrm{E}-29$ & -1.5 & & [83] & \\
\hline 83 & $\mathrm{e}+\mathrm{O}^{+}+\mathrm{O}_{2} \rightarrow \mathrm{O}+\mathrm{O}_{2}$ & $2.49 \mathrm{E}-29$ & -1.5 & & [83] & \\
\hline 84 & $\mathrm{e}+\mathrm{N}_{2} \mathrm{O}^{+} \rightarrow \mathrm{N}_{2}+\mathrm{O}$ & $3.22 \mathrm{E}-8$ & -0.5 & & {$[80,81]$} & \\
\hline 85 & $\mathrm{e}+\mathrm{NO}_{2}^{+} \rightarrow \mathrm{NO}+\mathrm{O}$ & $3.22 \mathrm{E}-8$ & -0.5 & & {$[80,81]$} & \\
\hline 86 & $\mathrm{e}+\mathrm{N}_{2} \mathrm{O}_{2}^{+} \rightarrow \mathrm{NO}+\mathrm{NO}$ & $3.61 \mathrm{E}-6$ & -0.5 & & [87] & \\
\hline 87 & $\mathrm{e}+\mathrm{N}_{2} \mathrm{O}_{2}^{+} \rightarrow \mathrm{N}_{2}+\mathrm{O}_{2}$ & $3.61 \mathrm{E}-6$ & -0.5 & & [87] & \\
\hline 88 & $\mathrm{e}+\mathrm{N}_{3}^{+} \rightarrow \mathrm{N}_{2}+\mathrm{N}$ & $5.56 \mathrm{E}-7$ & -0.5 & & {$[87]$} & \\
\hline 89 & $\mathrm{e}+\mathrm{N}_{3}^{+} \rightarrow \mathrm{N}_{2}\left(A^{3} \Sigma_{\mathrm{u}}^{+}\right)+\mathrm{N}$ & $6.91 \mathrm{E}-8$ & -0.5 & & {$[87]$} & \\
\hline \multirow[t]{2}{*}{90} & $\mathrm{e}+\mathrm{N}_{3}^{+} \rightarrow \mathrm{N}_{2}\left(B^{3} \Pi_{\mathrm{g}}\right)+\mathrm{N}$ & $6.91 \mathrm{E}-8$ & -0.5 & & {$[87]$} & \\
\hline & Reaction & $d$ & $e$ & $f$ & $T_{\mathrm{g}}(\mathrm{K})$ & References \\
\hline \multicolumn{7}{|c|}{ Heavy particle chemistry: ground neutrals (1) } \\
\hline 91 & $\mathrm{~N}+\mathrm{O}_{2} \rightarrow \mathrm{NO}+\mathrm{O}$ & $1.0 \mathrm{E}-11$ & 0 & 3473 & $200-1000$ & [83] \\
\hline 92 & $\mathrm{~N}+\mathrm{NO}_{2} \rightarrow 2 \mathrm{O}+\mathrm{N}_{2}$ & $9.1 \mathrm{E}-13$ & & & & {$[69]$} \\
\hline 93 & $\mathrm{~N}+\mathrm{NO}_{2} \rightarrow \mathrm{O}+\mathrm{N}_{2} \mathrm{O}$ & $3.0 \mathrm{E}-12$ & & & & [69] \\
\hline 94 & $\mathrm{~N}+\mathrm{NO}_{2} \rightarrow \mathrm{O}_{2}+\mathrm{N}_{2}$ & $7.0 \mathrm{E}-13$ & & & & [69] \\
\hline 95 & $\mathrm{~N}+\mathrm{NO}_{2} \rightarrow \mathrm{NO}+\mathrm{NO}$ & $2.3 \mathrm{E}-12$ & & & & [69] \\
\hline 96 & $\mathrm{NO}_{2}+\mathrm{NO}_{3}+\mathrm{O}_{2} \rightarrow \mathrm{N}_{2} \mathrm{O}_{5}+\mathrm{O}_{2}$ & $5.9 \mathrm{E}-29$ & -1.27 & & & [87] \\
\hline 97 & $\mathrm{NO}_{2}+\mathrm{NO}_{3}+\mathrm{N}_{2} \rightarrow \mathrm{N}_{2} \mathrm{O}_{5}+\mathrm{N}_{2}$ & $5.9 \mathrm{E}-29$ & -1.27 & & & {$[87]$} \\
\hline 98 & $\mathrm{NO}_{2}+\mathrm{NO}_{3}+\mathrm{NO} \rightarrow \mathrm{N}_{2} \mathrm{O}_{5}+\mathrm{NO}$ & $5.9 \mathrm{E}-29$ & -1.27 & & & [87] \\
\hline 99 & $\mathrm{NO}_{2}+\mathrm{NO}_{3}+\mathrm{N}_{2} \mathrm{O}_{5} \rightarrow 2 \mathrm{~N}_{2} \mathrm{O}_{5}$ & $5.9 \mathrm{E}-29$ & -1.27 & & & [87] \\
\hline 100 & $\mathrm{~N}_{2} \mathrm{O}_{5}+\mathrm{N}_{2} \rightarrow \mathrm{NO}_{2}+\mathrm{NO}_{3}+\mathrm{N}_{2}$ & $2.1 \mathrm{E}-11$ & -4.4 & 11080 & & [69] \\
\hline 101 & $\mathrm{~N}_{2} \mathrm{O}_{5}+\mathrm{O}_{2} \rightarrow \mathrm{NO}_{2}+\mathrm{NO}_{3}+\mathrm{O}_{2}$ & $2.1 \mathrm{E}-11$ & -4.4 & 11080 & & [69] \\
\hline 102 & $\mathrm{~N}_{2} \mathrm{O}_{5}+\mathrm{Ar} \rightarrow \mathrm{NO}_{2}+\mathrm{NO}_{3}+\mathrm{Ar}$ & $2.1 \mathrm{E}-11$ & -4.4 & 11080 & & [69] \\
\hline 103 & $\mathrm{~N}_{2} \mathrm{O}_{5}+\mathrm{O} \rightarrow \mathrm{N}_{2}+3 \mathrm{O}_{2}$ & $3.0 \mathrm{E}-16$ & 0.5 & & & [83] \\
\hline 104 & $\mathrm{NO}_{2}+\mathrm{O}_{3} \rightarrow \mathrm{NO}_{3}+\mathrm{O}_{2}$ & $1.2 \mathrm{E}-13$ & 0 & 2450 & $230-360$ & [69] \\
\hline \multicolumn{7}{|c|}{ Heavy particle chemistry: ground neutrals (2) } \\
\hline 105 & $\mathrm{O}+\mathrm{NO}_{2}+\mathrm{N}_{2} \rightarrow \mathrm{NO}_{3}+\mathrm{N}_{2}$ & $8.9 \mathrm{E}-32$ & -2.0 & & & [69] \\
\hline 106 & $\mathrm{O}+\mathrm{NO}_{2}+\mathrm{O}_{2} \rightarrow \mathrm{NO}_{3}+\mathrm{O}_{2}$ & $8.9 \mathrm{E}-32$ & -2.0 & & & [69] \\
\hline 107 & $\mathrm{O}+\mathrm{NO}_{3} \rightarrow \mathrm{NO}_{2}+\mathrm{O}_{2}$ & $1.0 \mathrm{E}-11$ & & & & [83] \\
\hline 108 & $\mathrm{NO}+\mathrm{NO}_{3} \rightarrow 2 \mathrm{NO}_{2}$ & $1.11 \mathrm{E}-11$ & & & & [69] \\
\hline 109 & $\mathrm{O}+\mathrm{NO}_{2} \rightarrow \mathrm{O}_{2}+\mathrm{NO}$ & $9.09 \mathrm{E}-12$ & 0.18 & & & [83] \\
\hline 110 & $\mathrm{~N}+\mathrm{O}_{3} \rightarrow \mathrm{NO}+\mathrm{O}_{2}$ & $2.0 \mathrm{E}-16$ & & & & [83] \\
\hline 111 & $\mathrm{O}+\mathrm{NO}+\mathrm{N}_{2} \rightarrow \mathrm{NO}_{2}+\mathrm{N}_{2}$ & $1.2 \mathrm{E}-31$ & -1.682 & & $200-2500$ & [69] \\
\hline 112 & $\mathrm{O}+\mathrm{NO}+\mathrm{O}_{2} \rightarrow \mathrm{NO}_{2}+\mathrm{O}_{2}$ & $9.3 \mathrm{E}-32$ & -1.682 & & $200-2500$ & [69] \\
\hline 113 & $\mathrm{O}+\mathrm{NO} \rightarrow \mathrm{NO}_{2}$ & $3.02 \mathrm{E}-11$ & -0.75 & & $200-2500$ & [88] \\
\hline 114 & $\mathrm{O}+\mathrm{NO} \rightarrow \mathrm{O}_{2}+\mathrm{N}$ & $8.93 \mathrm{E}-13$ & 1 & 19494.5 & $200-2500$ & [88] \\
\hline 115 & $\mathrm{~N}+\mathrm{NO} \rightarrow \mathrm{N}_{2}+\mathrm{O}$ & $3.51 \mathrm{E}-11$ & 0 & 49.84 & 196-3000 & [88] \\
\hline 116 & $\mathrm{O}_{3}+\mathrm{NO} \rightarrow \mathrm{O}_{2}+\mathrm{NO}_{2}$ & $4.3 \mathrm{E}-12$ & 0 & 1560 & & [83] \\
\hline 117 & $\mathrm{~N}+\mathrm{N}+\mathrm{N}_{2} \rightarrow \mathrm{N}_{2}+\mathrm{N}_{2}$ & $8.27 \mathrm{E}-34$ & 0 & -500 & & [83] \\
\hline 118 & $\mathrm{~N}+\mathrm{N}+\mathrm{N} \rightarrow \mathrm{N}_{2}+\mathrm{N}$ & $3.31 \mathrm{E}-27$ & -1.5 & & & {$[87]$} \\
\hline 119 & $\mathrm{O}+\mathrm{O}+\mathrm{N}_{2} \rightarrow \mathrm{O}_{2}+\mathrm{N}_{2}$ & $6.49 \mathrm{E}-35$ & 0 & -1039 & $190-4000$ & {$[69]$} \\
\hline
\end{tabular}




\begin{tabular}{|c|c|c|c|c|c|c|}
\hline & Reaction & $d$ & $e$ & $f$ & $T_{\mathrm{g}}(\mathrm{K})$ & References \\
\hline 120 & $\mathrm{O}+\mathrm{O}+\mathrm{N} \rightarrow \mathrm{O}_{2}+\mathrm{N}$ & $3.2 \mathrm{E}-33$ & -0.41 & & $290-4000$ & [69] \\
\hline 121 & $\mathrm{O}+\mathrm{O}_{2}+\mathrm{O}_{2} \rightarrow \mathrm{O}_{3}+\mathrm{O}_{2}$ & $7.6 \mathrm{E}-34$ & -1.9 & & $200-4000$ & [69] \\
\hline 122 & $\mathrm{O}+\mathrm{O}_{2}+\mathrm{N}_{2} \rightarrow \mathrm{O}_{3}+\mathrm{N}_{2}$ & $5.8 \mathrm{E}-34$ & -2.8 & & $200-4000$ & [69] \\
\hline 123 & $\mathrm{O}+\mathrm{O}_{2}+\mathrm{O}_{3} \rightarrow 2 \mathrm{O}_{3}$ & $1.5 \mathrm{E}-34$ & 0 & -750 & & [87] \\
\hline 124 & $\mathrm{O}+\mathrm{O}_{2}+\mathrm{O} \rightarrow \mathrm{O}_{3}+\mathrm{O}$ & $2.15 \mathrm{E}-34$ & 0 & -345 & $200-4000$ & [69] \\
\hline 125 & $\mathrm{O}+\mathrm{O}_{3} \rightarrow 2 \mathrm{O}_{2}$ & $2.0 \mathrm{E}-11$ & 0 & 2300 & $220-1000$ & [83] \\
\hline 126 & $\mathrm{~N}+\mathrm{O}+\mathrm{N}_{2} \rightarrow \mathrm{NO}+\mathrm{N}_{2}$ & $1.0 \mathrm{E}-32$ & -0.5 & & $200-4000$ & [69] \\
\hline 127 & $\mathrm{~N}+\mathrm{O}+\mathrm{O}_{2} \rightarrow \mathrm{NO}+\mathrm{O}_{2}$ & $1.0 \mathrm{E}-32$ & -0.5 & & $200-4000$ & [69] \\
\hline 128 & $\mathrm{NO}_{2}+\mathrm{N}_{2} \rightarrow \mathrm{NO}+\mathrm{O}+\mathrm{N}_{2}$ & $6.8 \mathrm{E}-6$ & -2 & 36180 & $200-4000$ & [69] \\
\hline 129 & $\mathrm{NO}_{2}+\mathrm{O}_{2} \rightarrow \mathrm{NO}+\mathrm{O}+\mathrm{O}_{2}$ & $5.3 \mathrm{E}-6$ & -2 & 36180 & $200-4000$ & [69] \\
\hline 130 & $\mathrm{NO}_{2}+\mathrm{NO} \rightarrow 2 \mathrm{NO}+\mathrm{O}$ & $5.3 \mathrm{E}-5$ & -2 & 36180 & $200-4000$ & [69] \\
\hline 131 & $\mathrm{NO}_{2}+\mathrm{NO}_{2} \rightarrow \mathrm{NO}+\mathrm{O}+\mathrm{NO}_{2}$ & $4.0 \mathrm{E}-5$ & -2 & 36180 & $200-4000$ & [69] \\
\hline 132 & $\mathrm{NO}_{2}+\mathrm{Ar} \rightarrow \mathrm{NO}+\mathrm{O}+\mathrm{Ar}$ & $4.0 \mathrm{E}-6$ & -2 & 36180 & $200-4000$ & [69] \\
\hline 133 & $\mathrm{NO}_{3}+\mathrm{N}_{2} \rightarrow \mathrm{NO}_{2}+\mathrm{O}+\mathrm{N}_{2}$ & $3.1 \mathrm{E}-5$ & -2 & 25000 & $200-1500$ & [69] \\
\hline 134 & $\mathrm{NO}_{3}+\mathrm{O}_{2} \rightarrow \mathrm{NO}_{2}+\mathrm{O}+\mathrm{O}_{2}$ & $3.1 \mathrm{E}-5$ & -2 & 25000 & $200-1500$ & [69] \\
\hline 135 & $\mathrm{NO}_{3}+\mathrm{NO} \rightarrow \mathrm{NO}_{2}+\mathrm{O}+\mathrm{NO}$ & $3.1 \mathrm{E}-5$ & -2 & 25000 & $200-1500$ & [69] \\
\hline 136 & $\mathrm{NO}_{3}+\mathrm{N} \rightarrow \mathrm{NO}_{2}+\mathrm{O}+\mathrm{N}$ & $3.1 \mathrm{E}-4$ & -2 & 25000 & $200-1500$ & [69] \\
\hline 137 & $\mathrm{NO}_{3}+\mathrm{O} \rightarrow \mathrm{NO}_{2}+\mathrm{O}+\mathrm{O}$ & $3.1 \mathrm{E}-4$ & -2 & 25000 & $200-1500$ & [69] \\
\hline 138 & $\mathrm{NO}_{3}+\mathrm{Ar} \rightarrow \mathrm{NO}_{2}+\mathrm{O}+\mathrm{Ar}$ & $3.72 \mathrm{E}-5$ & -2 & 25000 & $200-1500$ & [69] \\
\hline 139 & $\mathrm{NO}_{3}+\mathrm{N}_{2} \rightarrow \mathrm{NO}+\mathrm{O}_{2}+\mathrm{N}_{2}$ & $6.2 \mathrm{E}-5$ & -2 & 25000 & $200-1500$ & [69] \\
\hline 140 & $\mathrm{NO}_{3}+\mathrm{O}_{2} \rightarrow \mathrm{NO}+\mathrm{O}_{2}+\mathrm{O}_{2}$ & $6.2 \mathrm{E}-5$ & -2 & 25000 & $200-1500$ & [69] \\
\hline 141 & $\mathrm{NO}_{3}+\mathrm{NO} \rightarrow \mathrm{NO}+\mathrm{O}_{2}+\mathrm{NO}$ & $6.2 \mathrm{E}-5$ & -2 & 25000 & $200-1500$ & [69] \\
\hline 142 & $\mathrm{NO}_{3}+\mathrm{N} \rightarrow \mathrm{NO}+\mathrm{O}_{2}+\mathrm{N}$ & $7.44 \mathrm{E}-4$ & -2 & 25000 & $200-1500$ & [69] \\
\hline 143 & $\mathrm{NO}_{3}+\mathrm{O} \rightarrow \mathrm{NO}+\mathrm{O}_{2}+\mathrm{O}$ & $7.44 \mathrm{E}-4$ & -2 & 25000 & $200-1500$ & [69] \\
\hline 144 & $\mathrm{NO}_{3}+\mathrm{Ar} \rightarrow \mathrm{NO}+\mathrm{O}_{2}+\mathrm{Ar}$ & $7.44 \mathrm{E}-5$ & -2 & 25000 & $200-1500$ & [69] \\
\hline 145 & $\mathrm{CO}_{2}+\mathrm{O} \rightarrow \mathrm{CO}+\mathrm{O}_{2}$ & $2.81 \mathrm{E}-11$ & 0 & 26474 & $300-2500$ & {$[88]$} \\
\hline 146 & $\mathrm{CO}+\mathrm{O}+\mathrm{N}_{2} \rightarrow \mathrm{CO}_{2}+\mathrm{N}_{2}$ & $1.7 \mathrm{E}-33$ & 0 & 1510 & $250-4000$ & [88] \\
\hline 147 & $\mathrm{CO}+\mathrm{O}_{2} \rightarrow \mathrm{CO}_{2}+\mathrm{O}$ & $4.2 \mathrm{E}-12$ & 0 & 24000 & $300-6000$ & [88] \\
\hline 148 & $\mathrm{CO}+\mathrm{NO}_{2} \rightarrow \mathrm{CO}_{2}+\mathrm{NO}$ & $1.48 \mathrm{E}-10$ & 0 & 16967 & $300-2000$ & {$[88]$} \\
\hline \multicolumn{7}{|c|}{ Heavy particle chemistry: vibrational-vibrational processes } \\
\hline 149 & $\mathrm{~N}_{2}\left(v_{1}\right)+\mathrm{N}_{2}\left(v_{1}\right) \rightarrow \mathrm{N}_{2}\left(v_{2}\right)+\mathrm{N}_{2}$ & $3.0 \mathrm{E}-14$ & & & 200 & [89] \\
\hline 150 & $\mathrm{~N}_{2}\left(v_{1}\right)+\mathrm{N}_{2}\left(v_{2}\right) \rightarrow \mathrm{N}_{2}\left(v_{3}\right)+\mathrm{N}_{2}$ & $4.0 \mathrm{E}-14$ & & & 200 & [89] \\
\hline 151 & $\mathrm{~N}_{2}\left(v_{1}\right)+\mathrm{N}_{2}\left(v_{3}\right) \rightarrow \mathrm{N}_{2}\left(v_{4}\right)+\mathrm{N}_{2}$ & $5.0 \mathrm{E}-14$ & & & 200 & [89] \\
\hline 152 & $\mathrm{~N}_{2}\left(v_{1}\right)+\mathrm{N}_{2}\left(v_{4}\right) \rightarrow \mathrm{N}_{2}\left(v_{5}\right)+\mathrm{N}_{2}$ & $5.6 \mathrm{E}-14$ & & & 200 & [89] \\
\hline 153 & $\mathrm{~N}_{2}\left(v_{1}\right)+\mathrm{N}_{2}\left(v_{5}\right) \rightarrow \mathrm{N}_{2}\left(v_{6}\right)+\mathrm{N}_{2}$ & $6.0 \mathrm{E}-14$ & & & 200 & [89] \\
\hline 154 & $\mathrm{~N}_{2}\left(v_{1}\right)+\mathrm{N}_{2}\left(v_{6}\right) \rightarrow \mathrm{N}_{2}\left(v_{7}\right)+\mathrm{N}_{2}$ & $5.6 \mathrm{E}-14$ & & & 200 & [89] \\
\hline 155 & $\mathrm{~N}_{2}\left(v_{1}\right)+\mathrm{N}_{2}\left(v_{7}\right) \rightarrow \mathrm{N}_{2}\left(v_{8}\right)+\mathrm{N}_{2}$ & $5.0 \mathrm{E}-14$ & & & 200 & [89] \\
\hline 156 & $\mathrm{~N}_{2}\left(v_{1}\right)+\mathrm{CO}_{2} \rightarrow \mathrm{CO}_{2}\left(\begin{array}{lll}0 & 0 & 1\end{array}\right)+\mathrm{N}_{2}$ & $3.96 \mathrm{E}-13$ & & & 220 & [90] \\
\hline 157 & $\mathrm{~N}_{2}+\mathrm{CO}_{2}\left(\begin{array}{lll}0 & 0 & 1\end{array}\right) \rightarrow \mathrm{CO}_{2}+\mathrm{N}_{2}\left(v_{1}\right)$ & $4.33 \mathrm{E}-13$ & & & 220 & {$[90]$} \\
\hline \multicolumn{7}{|c|}{ Heavy particle chemistry: vibrational-translational processes } \\
\hline 158 & $\mathrm{~N}_{2}\left(v_{1}\right)+\mathrm{N}_{2} \rightarrow \mathrm{N}_{2}+\mathrm{N}_{2}$ & $3.5 \mathrm{E}-21$ & & & 500 & [91] \\
\hline 159 & $\mathrm{~N}_{2}\left(v_{2}\right)+\mathrm{N}_{2} \rightarrow \mathrm{N}_{2}\left(v_{1}\right)+\mathrm{N}_{2}$ & $6.5 \mathrm{E}-21$ & & & 500 & [91] \\
\hline 160 & $\mathrm{~N}_{2}\left(v_{3}\right)+\mathrm{N}_{2} \rightarrow \mathrm{N}_{2}\left(v_{2}\right)+\mathrm{N}_{2}$ & $1.5 \mathrm{E}-20$ & & & 500 & [91] \\
\hline 161 & $\mathrm{~N}_{2}\left(v_{4}\right)+\mathrm{N}_{2} \rightarrow \mathrm{N}_{2}\left(v_{3}\right)+\mathrm{N}_{2}$ & $2.5 \mathrm{E}-20$ & & & 500 & [91] \\
\hline 162 & $\mathrm{~N}_{2}\left(v_{5}\right)+\mathrm{N}_{2} \rightarrow \mathrm{N}_{2}\left(v_{4}\right)+\mathrm{N}_{2}$ & $3.5 \mathrm{E}-20$ & & & 500 & [91] \\
\hline 163 & $\mathrm{~N}_{2}\left(v_{6}\right)+\mathrm{N}_{2} \rightarrow \mathrm{N}_{2}\left(v_{5}\right)+\mathrm{N}_{2}$ & $7.0 \mathrm{E}-20$ & & & 500 & [91] \\
\hline 164 & $\mathrm{~N}_{2}\left(v_{7}\right)+\mathrm{N}_{2} \rightarrow \mathrm{N}_{2}\left(v_{6}\right)+\mathrm{N}_{2}$ & $1.0 \mathrm{E}-19$ & & & 500 & {$[91]$} \\
\hline \multicolumn{7}{|c|}{ Heavy particle chemistry: electronically excited neutrals (1) } \\
\hline 165 & $\operatorname{Ar}\left({ }^{3} \mathrm{P}_{2}\right)+\mathrm{N}_{2} \rightarrow \mathrm{Ar}+2 \mathrm{~N}$ & $3.6 \mathrm{E}-11$ & & & & [92] \\
\hline 166 & $\operatorname{Ar}\left({ }^{3} \mathrm{P}_{2}\right)+\mathrm{N}_{2} \rightarrow \operatorname{Ar}+\mathrm{N}_{2}\left(C^{3} \Pi_{\mathrm{u}}\right)$ & $3.0 \mathrm{E}-11$ & & & & [93] \\
\hline 167 & $\operatorname{Ar}\left({ }^{3} \mathrm{P}_{2}\right)+\mathrm{O}_{2} \rightarrow \mathrm{Ar}+2 \mathrm{O}$ & $2.1 \mathrm{E}-10$ & & & & [92] \\
\hline 168 & $\mathrm{Ar}\left({ }^{3} \mathrm{P}_{2}\right)+\mathrm{CO}_{2} \rightarrow \mathrm{Ar}+\mathrm{CO}+\mathrm{O}$ & $5.3 \mathrm{E}-10$ & & & & {$[92]$} \\
\hline 169 & $\operatorname{Ar}\left({ }^{3} \mathrm{P}_{2}\right)+\mathrm{NO} \rightarrow \mathrm{Ar}+\mathrm{N}+\mathrm{O}$ & $2.2 \mathrm{E}-10$ & & & & [92] \\
\hline 170 & $\operatorname{Ar}\left({ }^{3} \mathrm{P}_{2}\right)+\mathrm{N}_{2} \mathrm{O} \rightarrow \mathrm{Ar}+\mathrm{NO}+\mathrm{N}$ & $4.4 \mathrm{E}-10$ & & & & [92] \\
\hline 171 & $\operatorname{Ar}\left({ }^{3} \mathrm{P}_{2}\right)+\mathrm{N}_{2} \mathrm{O} \rightarrow \mathrm{Ar}+\mathrm{N}_{2}+\mathrm{O}$ & $4.4 \mathrm{E}-10$ & & & & {$[92]$} \\
\hline 172 & $\mathrm{~N}\left({ }^{2} \mathrm{D}\right)+\mathrm{O}_{2} \rightarrow \mathrm{NO}+\mathrm{O}$ & $1.5 \mathrm{E}-12$ & & & & {$[83]$} \\
\hline 173 & $\mathrm{~N}\left({ }^{2} \mathrm{D}\right)+\mathrm{O} \rightarrow \mathrm{N}+\mathrm{O}\left({ }^{1} \mathrm{D}\right)$ & $4.0 \mathrm{E}-13$ & & & & [69] \\
\hline 174 & $\mathrm{~N}\left({ }^{2} \mathrm{D}\right)+\mathrm{N}_{2} \rightarrow \mathrm{N}+\mathrm{N}_{2}$ & $6.0 \mathrm{E}-15$ & & & & {$[69]$} \\
\hline 175 & $\mathrm{~N}\left({ }^{2} \mathrm{D}\right)+\mathrm{NO} \rightarrow \mathrm{N}_{2}+\mathrm{O}$ & $1.8 \mathrm{E}-10$ & & & & [69] \\
\hline 176 & $\mathrm{~N}\left({ }^{2} \mathrm{D}\right)+\mathrm{N}_{2} \mathrm{O} \rightarrow \mathrm{NO}+\mathrm{N}_{2}$ & $3.5 \mathrm{E}-12$ & & & & {$[69]$} \\
\hline 177 & $\mathrm{~N}\left({ }^{2} \mathrm{P}\right)+\mathrm{N} \rightarrow \mathrm{N}\left({ }^{2} \mathrm{D}\right)+\mathrm{N}$ & $1.8 \mathrm{E}-12$ & & & & [69] \\
\hline 178 & $\mathrm{~N}\left({ }^{2} \mathrm{P}\right)+\mathrm{O}_{2} \rightarrow \mathrm{NO}+\mathrm{O}$ & $2.6 \mathrm{E}-15$ & & & & [69] \\
\hline 179 & $\mathrm{~N}\left({ }^{2} \mathrm{P}\right)+\mathrm{N}_{2} \rightarrow \mathrm{N}+\mathrm{N}_{2}$ & $2.0 \mathrm{E}-18$ & & & & [69] \\
\hline 180 & $\mathrm{~N}\left({ }^{2} \mathrm{P}\right)+\mathrm{NO} \rightarrow \mathrm{N}_{2}+\mathrm{O}$ & $3.0 \mathrm{E}-11$ & & & & [69] \\
\hline 181 & $\mathrm{~N}_{2}\left(a^{1} \Pi_{\mathrm{g}}\right)+\mathrm{N}_{2}\left(a^{1} \Pi_{\mathrm{g}}\right) \rightarrow \mathrm{N}_{2}+\mathrm{N}_{2}^{+}+\mathrm{e}$ & $2.0 \mathrm{E}-10$ & & & & {$[87]$} \\
\hline
\end{tabular}




\begin{tabular}{|c|c|c|c|c|c|c|}
\hline & Reaction & $d$ & $e$ & $f$ & $T_{\mathrm{g}}(\mathrm{K})$ & References \\
\hline $\begin{array}{l}182 \\
183 \\
184 \\
185 \\
186 \\
187\end{array}$ & $\begin{array}{l}\mathrm{N}_{2}\left(a^{1} \Pi_{\mathrm{g}}\right)+\mathrm{O}_{2} \rightarrow \mathrm{N}_{2}+2 \mathrm{O} \\
\mathrm{N}_{2}\left(a^{1} \Pi_{\mathrm{g}}\right)+\mathrm{N}_{2} \rightarrow \mathrm{N}_{2}+\mathrm{N}_{2} \\
\mathrm{~N}_{2}\left(a^{1} \Pi_{\mathrm{g}}\right)+\mathrm{NO} \rightarrow \mathrm{N}_{2}+\mathrm{N}+\mathrm{O} \\
\mathrm{N}_{2}\left(a^{\prime} \Sigma_{\mathrm{u}}\right)+\mathrm{N}_{2} \rightarrow \mathrm{N}_{2}\left(B^{3} \Pi_{\mathrm{g}}\right)+\mathrm{N}_{2} \\
\mathrm{~N}_{2}\left(a^{\prime} \Sigma_{\mathrm{u}}^{-}\right)+\mathrm{O}_{2} \rightarrow \mathrm{N}_{2}+2 \mathrm{O} \\
\mathrm{N}_{2}\left(a^{\prime} \Sigma_{\mathrm{u}}^{-}\right)+\mathrm{NO} \rightarrow \mathrm{N}_{2}+\mathrm{N}+\mathrm{O}\end{array}$ & $\begin{array}{l}2.8 \mathrm{E}-11 \\
2.0 \mathrm{E}-13 \\
3.6 \mathrm{E}-10 \\
2.0 \mathrm{E}-13 \\
2.8 \mathrm{E}-11 \\
3.6 \mathrm{E}-10\end{array}$ & & & & $\begin{array}{l}{[83]} \\
{[83]} \\
{[83]} \\
{[83]} \\
{[83]} \\
{[83]}\end{array}$ \\
\hline \multicolumn{7}{|c|}{ Heavy particle chemistry: electronically excited neutrals (2) } \\
\hline 188 & $\mathrm{~N}_{2}\left(a^{\prime}{ }^{1} \Sigma_{\mathrm{u}}^{-}\right)+\mathrm{N}_{2}\left(A^{3} \Sigma_{\mathrm{u}}^{+}\right) \rightarrow \mathrm{N}_{4}^{+}+\mathrm{e}$ & $1.5 \mathrm{E}-11$ & & & & [94] \\
\hline 189 & $\mathrm{~N}_{2}\left(a^{\prime} \Sigma_{\mathrm{u}}^{-}\right)+\mathrm{N}_{2}\left(a^{\prime} \Sigma^{1} \Sigma_{\mathrm{u}}^{-}\right) \rightarrow \mathrm{N}_{4}^{+}+\mathrm{e}$ & $1.0 \mathrm{E}-11$ & & & & [94] \\
\hline 190 & $\mathrm{~N}_{2}\left(C^{3} \Pi_{\mathrm{u}}\right)+\mathrm{N}_{2} \rightarrow \mathrm{N}_{2}\left(a^{\prime 1} \Sigma_{\mathrm{u}}^{-}\right)+\mathrm{N}_{2}$ & $1.0 \mathrm{E}-11$ & & & & {$[83]$} \\
\hline 191 & $\mathrm{~N}_{2}\left(C^{3} \Pi_{\mathrm{u}}\right)+\mathrm{O}_{2} \rightarrow \mathrm{N}_{2}+\mathrm{O}+\mathrm{O}\left({ }^{1} \mathrm{~S}\right)$ & $3.0 \mathrm{E}-10$ & & & & {$[69]$} \\
\hline 192 & $\mathrm{~N}_{2}\left(B^{3} \Pi_{\mathrm{g}}\right)+\mathrm{N}_{2} \rightarrow \mathrm{N}_{2}\left(A^{3} \Sigma_{\mathrm{u}}^{+}\right)+\mathrm{N}_{2}$ & $3.0 \mathrm{E}-11$ & & & & {$[69]$} \\
\hline 193 & $\mathrm{~N}_{2}\left(B^{3} \Pi_{\mathrm{g}}\right)+\mathrm{N}_{2} \rightarrow 2 \mathrm{~N}_{2}$ & $2.0 \mathrm{E}-12$ & & & & {$[69]$} \\
\hline 194 & $\mathrm{~N}_{2}\left(B^{3} \Pi_{\mathrm{g}}\right)+\mathrm{O}_{2} \rightarrow \mathrm{N}_{2}+\mathrm{O}+\mathrm{O}$ & $3.0 \mathrm{E}-10$ & & & & {$[69]$} \\
\hline 195 & $\mathrm{~N}_{2}\left(A^{3} \Sigma_{\mathrm{u}}^{+}\right)+\mathrm{N}_{2} \rightarrow 2 \mathrm{~N}_{2}$ & $3.0 \mathrm{E}-18$ & & & & {$[83]$} \\
\hline 196 & $\mathrm{~N}_{2}\left(A^{3} \Sigma_{\mathrm{u}}^{+}\right)+\mathrm{O}_{2} \rightarrow \mathrm{N}_{2}+2 \mathrm{O}$ & $2.54 \mathrm{E}-12$ & & & & {$[83]$} \\
\hline 197 & $\mathrm{~N}_{2}\left(A^{3} \Sigma_{u}^{+}\right)+\mathrm{O}_{2} \rightarrow \mathrm{N}_{2} \mathrm{O}+\mathrm{O}$ & $7.8 \mathrm{E}-12$ & & & & {$[83]$} \\
\hline 198 & $\mathrm{~N}_{2}\left(A^{3} \Sigma_{\mathrm{u}}^{+}\right)+\mathrm{O} \rightarrow \mathrm{NO}+\mathrm{N}\left({ }^{2} \mathrm{D}\right)$ & $7.0 \mathrm{E}-12$ & & & & {$[69]$} \\
\hline 199 & $\mathrm{~N}_{2}\left(A^{3} \Sigma_{\mathrm{u}}^{+}\right)+\mathrm{O} \rightarrow \mathrm{N}_{2}+\mathrm{O}\left({ }^{1} \mathrm{~S}\right)$ & $2.1 \mathrm{E}-11$ & & & & {$[83]$} \\
\hline 200 & $\mathrm{~N}_{2}\left(A^{3} \Sigma_{\mathrm{u}}^{+}\right)+\mathrm{N} \rightarrow \mathrm{N}_{2}+\mathrm{N}\left({ }^{2} \mathrm{P}\right)$ & $5.0 \mathrm{E}-11$ & & & & {$[69]$} \\
\hline 201 & $\mathrm{~N}_{2}\left(A^{3} \Sigma_{\mathrm{u}}^{+}\right)+\mathrm{N}_{2} \mathrm{O} \rightarrow \mathrm{N}_{2}+\mathrm{N}+\mathrm{NO}$ & $1.0 \mathrm{E}-11$ & & & & {$[83]$} \\
\hline 202 & $\mathrm{~N}_{2}\left(A^{3} \Sigma_{\mathrm{u}}^{+}\right)+\mathrm{N} \rightarrow \mathrm{N}_{2}+\mathrm{N}$ & $2.0 \mathrm{E}-11$ & & & & {$[69]$} \\
\hline 203 & $\mathrm{~N}_{2}\left(A^{3} \Sigma_{\mathrm{u}}^{+}\right)+\mathrm{NO} \rightarrow \mathrm{N}_{2}+\mathrm{NO}$ & $7.0 \mathrm{E}-11$ & & & & {$[83]$} \\
\hline 204 & $\mathrm{O}\left({ }^{1} \mathrm{D}\right)+\mathrm{N}_{2} \rightarrow \mathrm{O}+\mathrm{N}_{2}$ & $1.8 \mathrm{E}-11$ & 0 & -107 & & {$[83]$} \\
\hline 205 & $\mathrm{O}\left({ }^{1} \mathrm{D}\right)+\mathrm{O}_{2} \rightarrow \mathrm{O}+\mathrm{O}_{2}\left(b^{1} \Sigma_{\mathrm{g}}^{+}\right)$ & $2.56 \mathrm{E}-11$ & 0 & -67 & & {$[83]$} \\
\hline 206 & $\mathrm{O}\left({ }^{1} \mathrm{D}\right)+\mathrm{O}_{2} \rightarrow \mathrm{O}+\mathrm{O}_{2}\left(a^{1} \Delta_{\mathrm{g}}\right)$ & $1.0 \mathrm{E}-12$ & & & & [69] \\
\hline 207 & $\mathrm{O}\left({ }^{1} \mathrm{D}\right)+\mathrm{N}_{2} \mathrm{O} \rightarrow \mathrm{NO}+\mathrm{NO}$ & $7.2 \mathrm{E}-11$ & & & & {$[83]$} \\
\hline 208 & $\mathrm{O}\left({ }^{1} \mathrm{D}\right)+\mathrm{N}_{2} \mathrm{O} \rightarrow \mathrm{N}_{2} \mathrm{O}+\mathrm{O}$ & $1.0 \mathrm{E}-12$ & & & & {$[87]$} \\
\hline 209 & $\mathrm{O}\left({ }^{1} \mathrm{D}\right)+\mathrm{N}_{2} \mathrm{O} \rightarrow \mathrm{N}_{2}+\mathrm{O}_{2}$ & $4.9 \mathrm{E}-11$ & & & & {$[80,81]$} \\
\hline 210 & $\mathrm{O}\left({ }^{1} \mathrm{D}\right)+\mathrm{NO}_{2} \rightarrow \mathrm{O}_{2}+\mathrm{NO}$ & $3.0 \mathrm{E}-10$ & & & & {$[80,81]$} \\
\hline 211 & $\mathrm{O}\left({ }^{1} \mathrm{D}\right)+\mathrm{NO} \rightarrow \mathrm{O}_{2}+\mathrm{N}$ & $1.7 \mathrm{E}-10$ & & & & [83] \\
\hline 212 & $\mathrm{O}\left({ }^{1} \mathrm{D}\right)+\mathrm{O}_{3} \rightarrow 2 \mathrm{O}+\mathrm{O}_{2}$ & $1.2 \mathrm{E}-10$ & & & & {$[83]$} \\
\hline 213 & $\mathrm{O}\left({ }^{1} \mathrm{D}\right)+\mathrm{O}_{3} \rightarrow \mathrm{O}+\mathrm{O}_{3}$ & $2.41 \mathrm{E}-10$ & & & & {$[88]$} \\
\hline 214 & $\mathrm{O}\left({ }^{1} \mathrm{D}\right)+\mathrm{O}_{3} \rightarrow 2 \mathrm{O}_{2}$ & $2.4 \mathrm{E}-10$ & & & & {$[83]$} \\
\hline 215 & $\mathrm{O}\left({ }^{1} \mathrm{D}\right)+\mathrm{CO}_{2} \rightarrow \mathrm{O}+\mathrm{CO}_{2}$ & $7.4 \mathrm{E}-11$ & 0 & -120 & $200-300$ & {$[88]$} \\
\hline 216 & $\mathrm{O}\left({ }^{1} \mathrm{D}\right)+\mathrm{CO} \rightarrow \mathrm{CO}_{2}$ & $7.3 \mathrm{E}-11$ & & & $100-2100$ & {$[88]$} \\
\hline 217 & $\mathrm{O}\left({ }^{1} \mathrm{~S}\right)+\mathrm{NO} \rightarrow \mathrm{O}+\mathrm{NO}$ & $2.9 \mathrm{E}-10$ & & & & [69] \\
\hline 218 & $\mathrm{O}\left({ }^{1} \mathrm{~S}\right)+\mathrm{NO} \rightarrow \mathrm{O}\left({ }^{1} \mathrm{D}\right)+\mathrm{NO}$ & $5.1 \mathrm{E}-10$ & & & & [69] \\
\hline 219 & $\mathrm{O}\left({ }^{1} \mathrm{~S}\right)+\mathrm{O}_{2} \rightarrow \mathrm{O}_{2}+\mathrm{O}$ & $4.3 \mathrm{E}-12$ & 0 & 850 & & {$[83]$} \\
\hline 220 & $\mathrm{O}\left({ }^{1} \mathrm{~S}\right)+\mathrm{O}_{2}\left(a^{1} \Delta_{\mathrm{g}}\right) \rightarrow \mathrm{O}_{2}+\mathrm{O}\left({ }^{1} \mathrm{D}\right)$ & $3.6 \mathrm{E}-11$ & & & & {$[83]$} \\
\hline 221 & $\mathrm{O}\left({ }^{1} \mathrm{~S}\right)+\mathrm{O}_{2}\left(a^{1} \Delta_{\mathrm{g}}\right) \rightarrow 3 \mathrm{O}$ & $3.4 \mathrm{E}-11$ & & & & {$[83]$} \\
\hline 222 & $\mathrm{O}\left({ }^{1} \mathrm{~S}\right)+\mathrm{O}_{2}\left(a^{1} \Delta_{\mathrm{g}}\right) \rightarrow \mathrm{O}+\mathrm{O}_{2}\left(b^{1} \Sigma_{\mathrm{g}}^{+}\right)$ & $1.3 \mathrm{E}-10$ & & & & {$[83]$} \\
\hline 223 & $\mathrm{O}\left({ }^{1} \mathrm{~S}\right)+\mathrm{O} \rightarrow \mathrm{O}\left({ }^{1} \mathrm{D}\right)+\mathrm{O}$ & $5.0 \mathrm{E}-11$ & 0 & 301 & & {$[83]$} \\
\hline 224 & $\mathrm{O}\left({ }^{1} \mathrm{~S}\right)+\mathrm{O}_{3} \rightarrow \mathrm{O}_{2}+\mathrm{O}+\mathrm{O}\left({ }^{1} \mathrm{D}\right)$ & $2.9 \mathrm{E}-10$ & & & & {$[83]$} \\
\hline 225 & $\mathrm{O}\left({ }^{1} \mathrm{~S}\right)+\mathrm{O}_{3} \rightarrow 2 \mathrm{O}_{2}$ & $2.9 \mathrm{E}-10$ & & & & {$[83]$} \\
\hline 226 & $\mathrm{O}\left({ }^{1} \mathrm{~S}\right)+\mathrm{CO}_{2} \rightarrow \mathrm{O}+\mathrm{CO}_{2}$ & $3.09 \mathrm{E}-13$ & & & 300 & {$[88]$} \\
\hline 227 & $\mathrm{O}_{2}\left(a^{1} \Delta_{\mathrm{g}}\right)+\mathrm{N} \rightarrow \mathrm{O}+\mathrm{NO}$ & $2.0 \mathrm{E}-14$ & 0 & 600 & & {$[83]$} \\
\hline 228 & $\mathrm{O}_{2}\left(a^{1} \Delta_{\mathrm{g}}\right)+\mathrm{O} \rightarrow \mathrm{O}+\mathrm{O}_{2}$ & $7.0 \mathrm{E}-16$ & & & & {$[83]$} \\
\hline 229 & $\mathrm{O}_{2}\left(a^{1} \Delta_{\mathrm{g}}\right)+\mathrm{O}_{2} \rightarrow \mathrm{O}_{2}+\mathrm{O}_{2}$ & $2.2 \mathrm{E}-18$ & 0.8 & & & {$[83]$} \\
\hline 230 & $\mathrm{O}_{2}\left(a^{1} \Delta_{\mathrm{g}}\right)+\mathrm{N}_{2} \rightarrow \mathrm{O}_{2}+\mathrm{N}_{2}$ & $1.4 \mathrm{E}-19$ & & & & {$[95]$} \\
\hline 231 & $\mathrm{O}_{2}\left(a^{1} \Delta_{\mathrm{g}}\right)+\mathrm{NO} \rightarrow \mathrm{O}+\mathrm{NO}_{2}$ & $4.88 \mathrm{E}-18$ & & & & [88] \\
\hline \multicolumn{7}{|c|}{ Heavy particle chemistry: electronically excited neutrals (3) } \\
\hline 232 & $\mathrm{O}_{2}\left(a^{1} \Delta_{\mathrm{g}}\right)+\mathrm{O}_{3} \rightarrow 2 \mathrm{O}_{2}+\mathrm{O}$ & $5.2 \mathrm{E}-11$ & 0 & 2841 & $280-360$ & {$[88]$} \\
\hline 233 & $\mathrm{O}_{2}\left(a^{1} \Delta_{\mathrm{g}}\right)+\mathrm{NO} \rightarrow \mathrm{NO}+\mathrm{O}_{2}$ & $2.5 \mathrm{E}-11$ & & & & {$[83]$} \\
\hline 234 & $\mathrm{O}_{2}\left(b^{1} \Sigma_{\mathrm{g}}^{+}\right)+\mathrm{N}_{2} \rightarrow \mathrm{O}_{2}\left(a^{1} \Delta_{\mathrm{g}}\right)+\mathrm{N}_{2}$ & $4.9 \mathrm{E}-15$ & 0 & 253 & & [83] \\
\hline 235 & $\mathrm{O}_{2}\left(b^{1} \Sigma_{\mathrm{g}}^{+}\right)+\mathrm{O}_{2} \rightarrow \mathrm{O}_{2}\left(a^{1} \Delta_{\mathrm{g}}\right)+\mathrm{O}_{2}$ & $3.73 \mathrm{E}-16$ & 2.4 & 241 & & {$[83]$} \\
\hline 236 & $\mathrm{O}_{2}\left(b^{1} \Sigma_{\mathrm{g}}^{+}\right)+\mathrm{O} \rightarrow \mathrm{O}_{2}+\mathrm{O}$ & $8.0 \mathrm{E}-14$ & & & & {$[83]$} \\
\hline 237 & $\mathrm{O}_{2}\left(b^{1} \Sigma_{\mathrm{g}}^{+}\right)+\mathrm{O}_{3} \rightarrow 2 \mathrm{O}_{2}\left(a^{1} \Delta_{\mathrm{g}}\right)+\mathrm{O}$ & $1.8 \mathrm{E}-11$ & & & & {$[83]$} \\
\hline 238 & $\mathrm{O}_{2}\left(b^{1} \Sigma_{\mathrm{g}}^{+}\right)+\mathrm{NO} \rightarrow \mathrm{O}_{2}\left(a^{1} \Delta_{\mathrm{g}}\right)+\mathrm{NO}$ & $4.0 \mathrm{E}-14$ & & & & {$[83]$} \\
\hline 239 & $\mathrm{~N}_{2}\left(A^{3} \Sigma_{\mathrm{u}}^{+}\right)+\mathrm{NO} \rightarrow \mathrm{N}_{2}+\mathrm{NO}\left(A^{2} \Sigma^{+}\right)$ & $8.75 \mathrm{E}-11$ & & & & [96] \\
\hline 240 & $\mathrm{NO}\left(A^{2} \Sigma^{+}\right)+\mathrm{O}_{2} \rightarrow \mathrm{NO}+\mathrm{O}_{2}$ & $1.62 \mathrm{E}-10$ & & & & [96] \\
\hline 241 & $\mathrm{NO}\left(A^{2} \Sigma^{+}\right)+\mathrm{N}_{2} \rightarrow \mathrm{NO}+\mathrm{N}_{2}\left(A^{3} \Sigma_{\mathrm{u}}^{+}\right)$ & $5.0 \mathrm{E}-14$ & & & & [97] \\
\hline
\end{tabular}




\begin{tabular}{|c|c|c|c|c|c|c|}
\hline & Reaction & $d$ & $e$ & $f$ & $T_{\mathrm{g}}(\mathrm{K})$ & References \\
\hline \multicolumn{7}{|c|}{ Ionic chemistry: ion-ion recombination } \\
\hline 242 & $\mathrm{~N}_{2} \mathrm{O}_{2}^{+}+\mathrm{O}_{2}^{-} \rightarrow \mathrm{NO}+\mathrm{NO}+\mathrm{O}_{2}$ & $1.0 \mathrm{E}-7$ & & & & [87] \\
\hline 243 & $\mathrm{~N}_{2} \mathrm{O}_{2}^{+}+\mathrm{O}_{2}^{-} \rightarrow \mathrm{N}_{2}+\mathrm{O}_{2}+\mathrm{O}_{2}$ & $1.0 \mathrm{E}-7$ & & & & [87] \\
\hline 244 & $\mathrm{~N}_{2} \mathrm{O}_{2}^{+}+\mathrm{O}^{-} \rightarrow \mathrm{NO}+\mathrm{NO}+\mathrm{O}$ & $1.0 \mathrm{E}-7$ & & & & [87] \\
\hline 245 & $\mathrm{~N}_{2} \mathrm{O}_{2}^{+}+\mathrm{O}^{-} \rightarrow \mathrm{N}_{2}+\mathrm{O}+\mathrm{O}_{2}$ & $1.0 \mathrm{E}-7$ & & & & [87] \\
\hline 246 & $\mathrm{~N}_{2} \mathrm{O}_{2}^{+}+\mathrm{O}_{3}^{-} \rightarrow \mathrm{NO}+\mathrm{NO}+\mathrm{O}_{3}$ & $1.0 \mathrm{E}-7$ & & & & [87] \\
\hline 247 & $\mathrm{~N}_{2} \mathrm{O}_{2}^{+}+\mathrm{O}_{3}^{-} \rightarrow \mathrm{N}_{2}+\mathrm{O}_{2}+\mathrm{O}_{3}$ & $1.0 \mathrm{E}-7$ & & & & [87] \\
\hline 248 & $\mathrm{~N}_{2} \mathrm{O}_{2}^{+}+\mathrm{NO}^{-} \rightarrow \mathrm{NO}+\mathrm{NO}+\mathrm{NO}$ & $1.0 \mathrm{E}-7$ & & & & {$[87]$} \\
\hline 249 & $\mathrm{~N}_{2} \mathrm{O}_{2}^{+}+\mathrm{NO}^{-} \rightarrow \mathrm{NO}+\mathrm{N}_{2}+\mathrm{O}_{2}$ & $1.0 \mathrm{E}-7$ & & & & [87] \\
\hline 250 & $\mathrm{~N}_{2} \mathrm{O}_{2}^{+}+\mathrm{NO}_{2}^{-} \rightarrow \mathrm{NO}+\mathrm{NO}+\mathrm{NO}_{2}$ & $1.0 \mathrm{E}-7$ & & & & [87] \\
\hline 251 & $\mathrm{~N}_{2} \mathrm{O}_{2}^{+}+\mathrm{NO}_{2}^{-} \rightarrow \mathrm{NO}_{2}+\mathrm{N}_{2}+\mathrm{O}_{2}$ & $1.0 \mathrm{E}-7$ & & & & [87] \\
\hline 252 & $\mathrm{~N}_{2} \mathrm{O}_{2}^{+}+\mathrm{NO}_{3}^{-} \rightarrow \mathrm{NO}+\mathrm{NO}+\mathrm{NO}_{3}$ & $1.0 \mathrm{E}-7$ & & & & [87] \\
\hline 253 & $\mathrm{~N}_{2} \mathrm{O}_{2}^{+}+\mathrm{NO}_{3}^{-} \rightarrow \mathrm{NO}_{3}+\mathrm{N}_{2}+\mathrm{O}_{2}$ & $1.0 \mathrm{E}-7$ & & & & [87] \\
\hline 254 & $\mathrm{~N}_{3}^{+}+\mathrm{O}^{-} \rightarrow \mathrm{N}+\mathrm{N}_{2}+\mathrm{O}$ & $1.0 \mathrm{E}-7$ & & & & [87] \\
\hline 255 & $\mathrm{~N}_{3}^{+}+\mathrm{O}_{3}^{-} \rightarrow \mathrm{N}+\mathrm{N}_{2}^{-}+\mathrm{O}_{3}$ & $1.0 \mathrm{E}-7$ & & & & [87] \\
\hline 256 & $\mathrm{~N}_{3}^{+}+\mathrm{NO}^{-} \rightarrow \mathrm{N}+\mathrm{N}_{2}+\mathrm{NO}$ & $1.0 \mathrm{E}-7$ & & & & [87] \\
\hline 257 & $\mathrm{~N}_{3}^{+}+\mathrm{NO}_{3}^{-} \rightarrow \mathrm{N}+\mathrm{N}_{2}^{-}+\mathrm{NO}_{3}$ & $1.0 \mathrm{E}-7$ & & & & [87] \\
\hline 258 & $\mathrm{O}^{-}+\mathrm{NO}^{+}+\mathrm{O}_{2} \rightarrow \mathrm{NO}_{2}+\mathrm{O}_{2}$ & $2.0 \mathrm{E}-25$ & -2.5 & & & [69] \\
\hline 259 & $\mathrm{O}^{-}+\mathrm{O}_{2}^{+} \rightarrow \mathrm{O}+\mathrm{O}_{2}$ & $2.0 \mathrm{E}-7$ & -0.5 & & & [69] \\
\hline 260 & $\mathrm{O}^{-}+\mathrm{O}_{2}^{+}+\mathrm{O}_{2} \rightarrow \mathrm{O}_{3}+\mathrm{O}_{2}$ & $2.0 \mathrm{E}-25$ & -2.5 & & & [69] \\
\hline 261 & $\mathrm{O}_{2}^{-}+\mathrm{O}_{2}^{+} \rightarrow \mathrm{O}_{2}+\mathrm{O}_{2}$ & $2.0 \mathrm{E}-7$ & -0.5 & & & [69] \\
\hline 262 & $\mathrm{O}_{2}^{-}+\mathrm{NO}^{+} \rightarrow \mathrm{O}_{2}+\mathrm{N}+\mathrm{O}$ & $1.0 \mathrm{E}-7$ & & & & [69] \\
\hline 263 & $\mathrm{O}_{2}^{-}+\mathrm{NO}^{+}+\mathrm{O}_{2} \rightarrow 2 \mathrm{O}_{2}+\mathrm{NO}$ & $2.0 \mathrm{E}-25$ & -2.5 & & & [69] \\
\hline 264 & $\mathrm{O}_{3}^{-}+\mathrm{O}^{+} \rightarrow \mathrm{O}_{3}+\mathrm{O}$ & $2.0 \mathrm{E}-7$ & -0.5 & & & [69] \\
\hline 265 & $\mathrm{O}_{3}^{-}+\mathrm{O}_{2}^{+} \rightarrow \mathrm{O}_{3}+\mathrm{O}_{2}$ & $2.0 \mathrm{E}-7$ & -0.5 & & & [69] \\
\hline 266 & $\mathrm{O}_{3}^{-}+\mathrm{O}_{2}^{+} \rightarrow 2 \mathrm{O}+\mathrm{O}_{3}$ & $1.0 \mathrm{E}-7$ & & & & [69] \\
\hline 267 & $\mathrm{O}_{3}^{-}+\mathrm{NO}^{+} \rightarrow \mathrm{O}_{3}+\mathrm{NO}$ & $2.0 \mathrm{E}-7$ & -0.5 & & & [69] \\
\hline 268 & $\mathrm{NO}_{3}^{-}+\mathrm{NO}^{+} \rightarrow \mathrm{NO}_{3}+\mathrm{N}+\mathrm{O}$ & $1.0 \mathrm{E}-7$ & & & & [69] \\
\hline 269 & $\mathrm{NO}_{3}^{-}+\mathrm{O}_{2}^{+} \rightarrow \mathrm{NO}_{3}+\mathrm{O}+\mathrm{O}$ & $1.0 \mathrm{E}-7$ & & & & [69] \\
\hline \multicolumn{7}{|c|}{ Ionic chemistry: positive ions } \\
\hline 270 & $\mathrm{Ar}^{+}+\mathrm{N}_{2} \rightarrow \mathrm{Ar}+\mathrm{N}_{2}^{+}$ & $1.1 \mathrm{E}-11$ & & & & {$[98]$} \\
\hline 271 & $\mathrm{Ar}^{+}+\mathrm{O}_{2} \rightarrow \mathrm{Ar}+\mathrm{O}_{2}^{+}$ & $4.6 \mathrm{E}-11$ & & & & [99] \\
\hline 272 & $\mathrm{~N}_{2}^{+}+\mathrm{N}_{2}+\mathrm{N} \rightarrow \mathrm{N}_{3}^{+}+\mathrm{N}_{2}$ & $9.0 \mathrm{E}-30$ & 0 & -400 & & [69] \\
\hline 273 & $\mathrm{~N}_{2}^{+}+\mathrm{O} \rightarrow \mathrm{N}_{2}+\mathrm{O}^{+}$ & $1.0 \mathrm{E}-11$ & -0.2 & & & [83] \\
\hline 274 & $\mathrm{~N}_{2}^{+}+\mathrm{O} \rightarrow \mathrm{NO}^{+}+\mathrm{N}$ & $1.3 \mathrm{E}-10$ & -0.5 & & & [83] \\
\hline 275 & $\mathrm{~N}_{2}^{+}+\mathrm{O}_{2} \rightarrow \mathrm{N}_{2}+\mathrm{O}_{2}^{+}$ & $6.0 \mathrm{E}-11$ & -0.5 & & & [83] \\
\hline 276 & $\mathrm{~N}_{2}^{+}+\mathrm{O}_{3} \rightarrow \mathrm{O}_{2}^{+}+\mathrm{O}+\mathrm{N}_{2}$ & $1.0 \mathrm{E}-10$ & & & & [69] \\
\hline 277 & $\mathrm{~N}_{2}^{+}+\mathrm{N}_{2} \mathrm{O} \rightarrow \mathrm{N}_{2} \mathrm{O}^{+}+\mathrm{N}_{2}$ & $5.0 \mathrm{E}-10$ & & & & [69] \\
\hline 278 & $\mathrm{~N}_{2}^{+}+\mathrm{N}_{2} \mathrm{O} \rightarrow \mathrm{NO}^{+}+\mathrm{N}+\mathrm{N}_{2}$ & $4.0 \mathrm{E}-10$ & & & & {$[69]$} \\
\hline 279 & $\mathrm{~N}_{2}^{+}+\mathrm{NO} \rightarrow \mathrm{NO}^{+}+\mathrm{N}_{2}$ & $3.3 \mathrm{E}-10$ & & & & [83] \\
\hline 280 & $\mathrm{~N}_{2}^{+}+\mathrm{N}_{2}+\mathrm{N}_{2} \rightarrow \mathrm{N}_{4}^{+}+\mathrm{N}_{2}$ & $5.2 \mathrm{E}-29$ & -2.2 & & & [69] \\
\hline 281 & $\mathrm{~N}_{3}^{+}+\mathrm{N}_{2}\left(A^{3} \Sigma_{\mathrm{u}}^{+}\right) \rightarrow \mathrm{N}_{3}^{+}+\mathrm{N}_{2}$ & $3.0 \mathrm{E}-10$ & & & & [87] \\
\hline 282 & $\mathrm{~N}_{3}^{+}+\mathrm{O}_{2} \rightarrow \mathrm{O}_{2}^{+}+\mathrm{N}+\mathrm{N}_{2}$ & $2.3 \mathrm{E}-11$ & & & & [83] \\
\hline 283 & $\mathrm{~N}_{3}^{+}+\mathrm{O}_{2} \rightarrow \mathrm{NO}_{2}^{+}+\mathrm{N}_{2}$ & $4.4 \mathrm{E}-11$ & & & & [83] \\
\hline 284 & $\mathrm{~N}_{3}^{+}+\mathrm{N} \rightarrow \mathrm{N}_{2}^{+}+\mathrm{N}_{2}$ & $6.6 \mathrm{E}-11$ & & & & [83] \\
\hline 285 & $\mathrm{~N}_{3}^{+}+\mathrm{NO} \rightarrow \mathrm{NO}^{+}+\mathrm{N}+\mathrm{N}_{2}$ & $7.0 \mathrm{E}-11$ & & & & [83] \\
\hline 286 & $\mathrm{~N}_{3}^{+}+\mathrm{O}_{2} \rightarrow \mathrm{N}+\mathrm{N}_{2}+\mathrm{O}_{2}^{+}$ & $2.3 \mathrm{E}-11$ & & & & [83] \\
\hline 287 & $\mathrm{~N}_{3}^{+}+\mathrm{NO} \rightarrow \mathrm{N}_{2}+\mathrm{N}_{2} \mathrm{O}^{+}$ & 7.0E -11 & & & & [87] \\
\hline 288 & $\mathrm{~N}_{4}^{+}+\mathrm{O}_{2} \rightarrow \mathrm{O}_{2}^{+}+\mathrm{N}_{2}+\mathrm{N}_{2}$ & $2.5 \mathrm{E}-10$ & & & & [69] \\
\hline 289 & $\mathrm{~N}_{4}^{+}+\mathrm{O} \rightarrow \mathrm{O}^{+}+\mathrm{N}_{2}+\mathrm{N}_{2}$ & $2.5 \mathrm{E}-10$ & & & & {$[69]$} \\
\hline 290 & $\mathrm{O}^{+}+\mathrm{N}_{2} \rightarrow \mathrm{NO}^{+}+\mathrm{N}$ & $3.0 \mathrm{E}-12$ & & & & [83] \\
\hline 291 & $\mathrm{O}^{+}+\mathrm{O}_{2} \rightarrow \mathrm{O}_{2}^{+}+\mathrm{O}$ & $2.0 \mathrm{E}-11$ & -0.5 & & & [69] \\
\hline 292 & $\mathrm{O}^{+}+\mathrm{O}_{3} \rightarrow \mathrm{O}_{2}^{+}+\mathrm{O}_{2}$ & $1.0 \mathrm{E}-10$ & & & & [69] \\
\hline 293 & $\mathrm{O}^{+}+\mathrm{NO} \rightarrow \mathrm{NO}^{+}+\mathrm{O}$ & $2.4 \mathrm{E}-11$ & & & & [69] \\
\hline 294 & $\mathrm{O}^{+}+\mathrm{NO} \rightarrow \mathrm{O}_{2}^{+}+\mathrm{N}$ & $3.0 \mathrm{E}-12$ & & & & [69] \\
\hline 295 & $\mathrm{O}^{+}+\mathrm{N}_{2} \mathrm{O} \rightarrow \mathrm{NO}^{+}+\mathrm{NO}$ & $2.3 \mathrm{E}-10$ & & & & [69] \\
\hline 296 & $\mathrm{O}^{+}+\mathrm{N}_{2} \mathrm{O} \rightarrow \mathrm{O}_{2}^{+}+\mathrm{N}_{2}$ & $2.0 \mathrm{E}-11$ & & & & [69] \\
\hline 297 & $\mathrm{O}^{+}+\mathrm{N}_{2} \mathrm{O} \rightarrow \mathrm{N}_{2} \mathrm{O}^{+}+\mathrm{O}$ & $2.2 \mathrm{E}-11$ & & & & [69] \\
\hline 298 & $\mathrm{O}^{+}+\mathrm{NO}_{2} \rightarrow \mathrm{NO}_{2}^{+}+\mathrm{O}$ & $1.6 \mathrm{E}-9$ & & & & [69] \\
\hline 299 & $\mathrm{O}_{2}^{+}+\mathrm{N} \rightarrow \mathrm{NO}^{+}+\mathrm{O}$ & $1.2 \mathrm{E}-10$ & & & & [83] \\
\hline 300 & $\mathrm{O}_{2}^{+}+\mathrm{N}_{2} \rightarrow \mathrm{NO}^{+}+\mathrm{NO}$ & $1.0 \mathrm{E}-17$ & & & & [83] \\
\hline 301 & $\mathrm{O}_{2}^{+}+\mathrm{NO}_{2} \rightarrow \mathrm{NO}^{+}+\mathrm{O}_{3}$ & $1.0 \mathrm{E}-11$ & & & & [69] \\
\hline 302 & $\mathrm{O}_{2}^{+}+\mathrm{NO}_{2} \rightarrow \mathrm{NO}_{2}^{+}+\mathrm{O}_{2}$ & $6.6 \mathrm{E}-10$ & & & & [69] \\
\hline 303 & $\mathrm{O}_{2}^{+}+\mathrm{NO} \rightarrow \mathrm{O}_{2}+\mathrm{NO}^{+}$ & $4.4 \mathrm{E}-10$ & & & & [83] \\
\hline 304 & $\mathrm{O}_{2}^{+}+\mathrm{O}_{2}+\mathrm{O}_{2} \rightarrow \mathrm{O}_{4}^{+}+\mathrm{O}_{2}$ & $2.4 \mathrm{E}-30$ & -3.2 & & & [83] \\
\hline
\end{tabular}




\begin{tabular}{|c|c|c|c|c|c|c|}
\hline & Reaction & $d$ & $e$ & $f$ & $T_{\mathrm{g}}(\mathrm{K})$ & References \\
\hline 305 & $\mathrm{O}_{2}^{+}+\mathrm{N}_{2}+\mathrm{N}_{2} \rightarrow \mathrm{N}_{2} \mathrm{O}_{2}^{+}+\mathrm{N}_{2}$ & $9.0 \mathrm{E}-31$ & -2 & & & {$[83]$} \\
\hline 306 & $\mathrm{O}_{4}^{+}+\mathrm{O}_{2}\left(a^{1} \Delta_{\mathrm{g}}\right) \rightarrow \mathrm{O}_{2}^{+}+\mathrm{O}_{2}+\mathrm{O}_{2}$ & $1.0 \mathrm{E}-10$ & & & & [83] \\
\hline 307 & $\mathrm{O}_{4}^{+}+\mathrm{O}_{2}\left(b^{1} \Sigma_{\mathrm{g}}^{+}\right) \rightarrow \mathrm{O}_{2}^{+}+\mathrm{O}_{2}+\mathrm{O}_{2}$ & $1.0 \mathrm{E}-10$ & & & & [83] \\
\hline 308 & $\mathrm{O}_{4}^{+}+\mathrm{N}_{2} \rightarrow \mathrm{N}_{2} \mathrm{O}_{2}^{+}+\mathrm{O}_{2}$ & $4.6 \mathrm{E}-12$ & 2.5 & 2650 & & [69] \\
\hline 309 & $\mathrm{O}_{4}^{+}+\mathrm{NO} \rightarrow \mathrm{NO}^{+}+\mathrm{O}_{2}+\mathrm{O}_{2}$ & $1.0 \mathrm{E}-10$ & & & & {$[83]$} \\
\hline 310 & $\mathrm{O}_{4}^{+}+\mathrm{O} \rightarrow \mathrm{O}_{2}^{+}+\mathrm{O}_{3}$ & $3.0 \mathrm{E}-10$ & & & & [83] \\
\hline 311 & $\mathrm{O}_{4}^{+}+\mathrm{O}_{2} \rightarrow \mathrm{O}_{2}^{+}+\mathrm{O}_{2}+\mathrm{O}_{2}$ & $3.3 \mathrm{E}-6$ & -4 & 5030 & & {$[83]$} \\
\hline 312 & $\mathrm{NO}_{2}^{+}+\mathrm{NO} \rightarrow \mathrm{NO}^{+}+\mathrm{NO}_{2}$ & $2.9 \mathrm{E}-10$ & & & & [69] \\
\hline 313 & $\mathrm{~N}_{2} \mathrm{O}^{+}+\mathrm{NO} \rightarrow \mathrm{NO}^{+}+\mathrm{N}_{2} \mathrm{O}$ & $2.9 \mathrm{E}-10$ & & & & [69] \\
\hline \multicolumn{7}{|c|}{ Ionic chemistry: negative ions (1) } \\
\hline 314 & $\mathrm{O}^{-}+\mathrm{N}_{2} \rightarrow \mathrm{N}_{2} \mathrm{O}+\mathrm{e}$ & $1.0 \mathrm{E}-12$ & & & & [69] \\
\hline 315 & $\mathrm{O}^{-}+\mathrm{O}_{2} \rightarrow \mathrm{O}_{3}+\mathrm{e}$ & $5.0 \mathrm{E}-15$ & & & & [83] \\
\hline 316 & $\mathrm{O}^{-}+\mathrm{O} \rightarrow \mathrm{O}_{2}+\mathrm{e}$ & $5.0 \mathrm{E}-10$ & & & & [83] \\
\hline 317 & $\mathrm{O}^{-}+\mathrm{N} \rightarrow \mathrm{NO}+\mathrm{e}$ & $2.6 \mathrm{E}-10$ & & & & [83] \\
\hline 318 & $\mathrm{O}^{-}+\mathrm{N}_{2}\left(A^{3} \Sigma_{\mathrm{u}}^{+}\right) \rightarrow \mathrm{O}+\mathrm{N}_{2}+\mathrm{e}$ & $2.2 \mathrm{E}-9$ & & & & [83] \\
\hline 319 & $\mathrm{O}^{-}+\mathrm{O}_{2}\left(a^{1} \Delta_{\mathrm{g}}\right) \rightarrow \mathrm{O}_{3}+\mathrm{e}$ & $3.0 \mathrm{E}-10$ & & & & {$[83]$} \\
\hline 320 & $\mathrm{O}^{-}+\mathrm{O}_{3} \rightarrow 2 \mathrm{O}_{2}+\mathrm{e}$ & $5.3 \mathrm{E}-10$ & & & & [83] \\
\hline 321 & $\mathrm{O}^{-}+\mathrm{NO} \rightarrow \mathrm{NO}_{2}+\mathrm{e}$ & $2.6 \mathrm{E}-10$ & & & & [83] \\
\hline 322 & $\mathrm{O}^{-}+\mathrm{N}_{2} \mathrm{O} \rightarrow \mathrm{NO}^{-}+\mathrm{NO}$ & $2.1 \mathrm{E}-10$ & & & & {$[83]$} \\
\hline 323 & $\mathrm{O}^{-}+\mathrm{NO}_{2} \rightarrow \mathrm{NO}_{2}^{-}+\mathrm{O}$ & $1.2 \mathrm{E}-9$ & & & & [83] \\
\hline 324 & $\mathrm{O}^{-}+\mathrm{O}_{2}+\mathrm{O}_{2} \rightarrow \mathrm{O}_{3}^{-}+\mathrm{O}_{2}$ & $1.1 \mathrm{E}-30$ & -1 & & & {$[83]$} \\
\hline 325 & $\mathrm{O}^{-}+\mathrm{O}_{3} \rightarrow \mathrm{O}_{3}^{-}+\mathrm{O}^{-}$ & $5.3 \mathrm{E}-10$ & & & & {$[83]$} \\
\hline 326 & $\mathrm{O}^{-}+\mathrm{O}_{2}\left(a^{1} \Delta_{\mathrm{g}}^{3}\right) \rightarrow \mathrm{O}_{2}^{-}+\mathrm{O}$ & $1.0 \mathrm{E}-10$ & & & & [69] \\
\hline 327 & $\mathrm{O}^{-}+\mathrm{N}_{2}\left(B^{3} \Pi_{\mathrm{g}}\right) \rightarrow \mathrm{O}+\mathrm{N}_{2}+\mathrm{e}$ & $1.9 \mathrm{E}-9$ & & & & {$[69]$} \\
\hline 328 & $\mathrm{O}^{-}+\mathrm{CO} \rightarrow \mathrm{CO}_{2}+\mathrm{e}$ & $6.0 \mathrm{E}-10$ & -0.32 & & & [100] \\
\hline 329 & $\mathrm{O}^{-}+\mathrm{CO}_{2}+\mathrm{Ar} \rightarrow \mathrm{CO}_{3}^{-}+\mathrm{Ar}$ & $3.1 \mathrm{E}-28$ & 0.5 & & & {$[101]$} \\
\hline 330 & $\mathrm{O}^{-}+2 \mathrm{CO}_{2} \rightarrow \mathrm{CO}_{3}^{-}+\mathrm{CO}_{2}$ & $3.1 \mathrm{E}-28$ & 0.5 & & & {$[101]$} \\
\hline 331 & $\mathrm{O}_{2}^{-}+\mathrm{O} \rightarrow \mathrm{O}^{-}+\mathrm{O}_{2}$ & $3.3 \mathrm{E}-10$ & & & & {$[83]$} \\
\hline 332 & $\mathrm{O}_{2}^{-}+\mathrm{O} \rightarrow \mathrm{O}_{3}+\mathrm{e}$ & $1.5 \mathrm{E}-10$ & & & & {$[83]$} \\
\hline 333 & $\mathrm{O}_{2}^{-}+\mathrm{O}_{2} \rightarrow \mathrm{O}_{2}+\mathrm{O}_{2}+\mathrm{e}$ & $2.7 \mathrm{E}-18$ & 0.5 & 5590 & & {$[83]$} \\
\hline 334 & $\mathrm{O}_{2}^{-}+\mathrm{O}_{2}\left(a^{1} \Delta_{\mathrm{g}}\right) \rightarrow \mathrm{O}_{2}+\mathrm{O}_{2}+\mathrm{e}$ & $2.0 \mathrm{E}-10$ & & & & {$[83]$} \\
\hline 335 & $\mathrm{O}_{2}^{-}+\mathrm{O}_{2}\left(b^{1} \Sigma_{\mathrm{g}}^{+}\right) \rightarrow \mathrm{O}_{2}+\mathrm{O}_{2}+\mathrm{e}$ & $3.6 \mathrm{E}-10$ & & & & {$[83]$} \\
\hline 336 & $\mathrm{O}_{2}^{-}+\mathrm{N}_{2} \rightarrow \mathrm{O}_{2}+\mathrm{N}_{2}+\mathrm{e}$ & $1.9 \mathrm{E}-12$ & 0.5 & 4990 & & {$[69]$} \\
\hline 337 & $\mathrm{O}_{2}^{-}+\mathrm{N} \rightarrow \mathrm{NO}_{2}+\mathrm{e}$ & $5.0 \mathrm{E}-10$ & & & & {$[83]$} \\
\hline 338 & $\mathrm{O}_{2}^{-}+\mathrm{NO}_{2} \rightarrow \mathrm{O}_{2}+\mathrm{NO}_{2}^{-}$ & $8.0 \mathrm{E}-10$ & & & & {$[83]$} \\
\hline 339 & $\mathrm{O}_{2}^{-}+\mathrm{O}_{3} \rightarrow \mathrm{O}_{2}+\mathrm{O}_{3}^{-}$ & $4.0 \mathrm{E}-10$ & & & & {$[83]$} \\
\hline 340 & $\mathrm{O}_{2}^{-}+\mathrm{N}_{2}\left(A^{3} \Sigma_{\mathrm{u}}^{+}\right) \rightarrow \mathrm{O}_{2}+\mathrm{N}_{2}+\mathrm{e}$ & $2.1 \mathrm{E}-9$ & & & & {$[69]$} \\
\hline 341 & $\mathrm{O}_{2}^{-}+\mathrm{N}_{2}\left(B^{3} \Pi_{\mathrm{g}}\right) \rightarrow \mathrm{O}_{2}+\mathrm{N}_{2}+\mathrm{e}$ & $2.5 \mathrm{E}-9$ & & & & [69] \\
\hline 342 & $\mathrm{O}_{3}^{-}+\mathrm{O} \rightarrow \mathrm{O}_{2}^{-}+\mathrm{O}_{2}$ & $2.5 \mathrm{E}-10$ & & & & [102] \\
\hline 343 & $\mathrm{O}_{3}^{-}+\mathrm{O} \rightarrow 2 \mathrm{O}_{2}+\mathrm{e}$ & $1.4 \mathrm{E}-10$ & & & & [83] \\
\hline 344 & $\mathrm{O}_{3}^{-}+\mathrm{NO} \rightarrow \mathrm{NO}_{3}^{-}+\mathrm{O}$ & $1.0 \mathrm{E}-11$ & & & & [83] \\
\hline 345 & $\mathrm{O}_{3}^{-}+\mathrm{NO}_{2} \rightarrow \mathrm{O}_{3}^{-}+\mathrm{NO}_{2}^{-}$ & $7.0 \mathrm{E}-10$ & & & & [83] \\
\hline 346 & $\mathrm{O}_{3}^{-}+\mathrm{NO}_{2} \rightarrow \mathrm{NO}_{3}^{-}+\mathrm{O}_{2}$ & $2.0 \mathrm{E}-11$ & & & & [83] \\
\hline 347 & $\mathrm{O}_{3}^{-}+\mathrm{NO} \rightarrow \mathrm{NO}_{2}^{-}+\mathrm{O}_{2}$ & $2.6 \mathrm{E}-11$ & & & & [69] \\
\hline 348 & $\mathrm{O}_{3}^{-}+\mathrm{O}_{3} \rightarrow 3 \mathrm{O}_{2}+\mathrm{e}$ & $1.0 \mathrm{E}-10$ & & & & [102] \\
\hline 349 & $\mathrm{O}_{3}^{-}+\mathrm{CO}_{2} \rightarrow \mathrm{CO}_{3}^{-}+\mathrm{O}_{2}$ & $5.5 \mathrm{E}-10$ & 0.5 & & & {$[101]$} \\
\hline 350 & $\mathrm{NO}^{-}+\mathrm{O}_{2} \rightarrow \mathrm{O}_{2}^{-}+\mathrm{NO}$ & $5.0 \mathrm{E}-10$ & & & & [83] \\
\hline 351 & $\mathrm{NO}^{-}+\mathrm{NO}_{2} \rightarrow \mathrm{NO}_{2}^{-}+\mathrm{NO}$ & $7.4 \mathrm{E}-16$ & & & & [83] \\
\hline 352 & $\mathrm{NO}^{-}+\mathrm{N}_{2} \mathrm{O} \rightarrow \mathrm{NO}_{2}^{-}+\mathrm{N}_{2}$ & $2.8 \mathrm{E}-14$ & & & & {$[83]$} \\
\hline 353 & $\mathrm{NO}^{-}+\mathrm{CO}_{2} \rightarrow \mathrm{NO}+\mathrm{CO}_{2}+\mathrm{e}$ & $8.3 \mathrm{E}-12$ & & & $193-506$ & [103] \\
\hline 354 & $\mathrm{NO}^{-}+\mathrm{CO} \rightarrow \mathrm{NO}+\mathrm{CO}+\mathrm{e}$ & $5.0 \mathrm{E}-13$ & & & $193-506$ & [103] \\
\hline 355 & $\mathrm{NO}^{-}+\mathrm{N}_{2} \mathrm{O} \rightarrow \mathrm{NO}+\mathrm{N}_{2} \mathrm{O}+\mathrm{e}$ & $5.1 \mathrm{E}-12$ & & & $193-506$ & [103] \\
\hline 356 & $\mathrm{NO}^{-}+\mathrm{NO} \rightarrow 2 \mathrm{NO}+\mathrm{e}$ & $5.0 \mathrm{E}-12$ & & & $285-506$ & [103] \\
\hline 357 & $\mathrm{NO}_{2}^{-}+\mathrm{O}_{3} \rightarrow \mathrm{O}_{2}+\mathrm{NO}_{3}^{-}$ & $1.8 \mathrm{E}-11$ & & & & [83] \\
\hline \multicolumn{7}{|c|}{ Ionic chemistry: negative ions (2) } \\
\hline 358 & $\mathrm{NO}_{2}^{-}+\mathrm{NO}_{2} \rightarrow \mathrm{NO}_{3}^{-}+\mathrm{NO}$ & $4.0 \mathrm{E}-12$ & & & & [69] \\
\hline 359 & $\mathrm{NO}_{2}^{-}+\mathrm{NO}_{3} \rightarrow \mathrm{NO}_{2}+\mathrm{NO}_{3}^{-}$ & $5.0 \mathrm{E}-10$ & & & & [69] \\
\hline 360 & $\mathrm{NO}_{3}^{-}+\mathrm{NO} \rightarrow \mathrm{NO}_{2}^{-}+\mathrm{NO}_{2}^{-}$ & $3.0 \mathrm{E}-15$ & & & & [69] \\
\hline 361 & $\mathrm{CO}_{3}^{-}+\mathrm{O} \rightarrow \mathrm{O}_{2}^{-}+\mathrm{CO}_{2}$ & $1.1 \mathrm{E}-10$ & 0.5 & & & {$[101]$} \\
\hline 362 & $\mathrm{CO}_{3}^{-}+\mathrm{NO} \rightarrow \mathrm{NO}_{2}^{-}+\mathrm{CO}_{2}$ & $1.1 \mathrm{E}-11$ & 0.5 & & & {$[101]$} \\
\hline 363 & $\mathrm{CO}_{3}^{-}+\mathrm{NO}_{2} \rightarrow \mathrm{NO}_{3}^{-}+\mathrm{CO}_{2}$ & $2.0 \mathrm{E}-10$ & 0.5 & & & {$[101]$} \\
\hline 364 & $\mathrm{CO}_{4}^{-}+\mathrm{O} \rightarrow \mathrm{CO}_{3}^{-}+\mathrm{O}_{2}$ & $1.3 \mathrm{E}-10$ & 0.5 & & & {$[101]$} \\
\hline 365 & $\mathrm{CO}_{4}^{-}+\mathrm{O}_{3} \rightarrow \mathrm{O}_{3}^{-}+\mathrm{CO}_{2}+\mathrm{O}_{2}$ & $1.4 \mathrm{E}-10$ & 0.5 & & & [101] \\
\hline 366 & $\mathrm{CO}_{4}^{-}+\mathrm{NO} \rightarrow \mathrm{NO}_{3}^{-}+\mathrm{CO}_{2}$ & $4.8 \mathrm{E}-11$ & & & & {$[100]$} \\
\hline
\end{tabular}




\begin{tabular}{|c|c|c|c|c|c|c|}
\hline & Reaction & $d$ & $e$ & $f$ & $T_{\mathrm{g}}(\mathrm{K})$ & References \\
\hline \multicolumn{7}{|c|}{ Humid air chemistry: ground neutrals (1) } \\
\hline 367 & $\mathrm{H}+\mathrm{O}_{2} \rightarrow \mathrm{O}+\mathrm{OH}$ & $3.7 \mathrm{E}-10$ & 0 & 8455 & & {$[87]$} \\
\hline 368 & $\mathrm{H}+\mathrm{O}_{2}+\mathrm{H}_{2} \rightarrow \mathrm{HO}_{2}+\mathrm{H}_{2}$ & $5.79 \mathrm{E}-32$ & -0.8 & 0 & & [104] \\
\hline 369 & $\mathrm{H}+\mathrm{O}_{2}+\mathrm{N}_{2} \rightarrow \mathrm{HO}_{2}+\mathrm{N}_{2}$ & $5.94 \mathrm{E}-32$ & -1.0 & 0 & & {$[105]$} \\
\hline 370 & $\mathrm{H}+\mathrm{O}_{2}+\mathrm{O}_{2} \rightarrow \mathrm{HO}_{2}+\mathrm{O}_{2}$ & $5.94 \mathrm{E}-32$ & -1.0 & 0 & & {$[105]$} \\
\hline 371 & $\mathrm{H}+\mathrm{OH}+\mathrm{N}_{2} \rightarrow \mathrm{H}_{2} \mathrm{O}+\mathrm{N}_{2}$ & $6.88 \mathrm{E}-31$ & -2.0 & 0 & & {$[104]$} \\
\hline 372 & $\mathrm{H}+\mathrm{OH}+\mathrm{O}_{2} \rightarrow \mathrm{H}_{2} \mathrm{O}+\mathrm{O}_{2}$ & $6.88 \mathrm{E}-31$ & -2.0 & 0 & & {$[104]$} \\
\hline 373 & $\mathrm{H}+\mathrm{NO}_{2} \rightarrow \mathrm{NO}+\mathrm{OH}$ & $2.2 \mathrm{E}-10$ & 0 & 182 & $296-760$ & {$[106]$} \\
\hline 374 & $\mathrm{H}+\mathrm{O}_{3} \rightarrow \mathrm{O}_{2}+\mathrm{OH}$ & $7.78 \mathrm{E}-11$ & 0.2551 & 327.8 & & [88] \\
\hline 375 & $\mathrm{H}+\mathrm{O}_{3} \rightarrow \mathrm{HO}_{2}+\mathrm{O}$ & $7.5 \mathrm{E}-13$ & & & & [88] \\
\hline 376 & $\mathrm{H}+\mathrm{HO}_{2} \rightarrow \mathrm{H}_{2}+\mathrm{O}_{2}$ & $2.57 \mathrm{E}-11$ & 0.5598 & 346 & & [88] \\
\hline 377 & $\mathrm{H}+\mathrm{HO}_{2} \rightarrow \mathrm{OH}+\mathrm{OH}$ & $2.35 \mathrm{E}-10$ & 0 & 373.7 & & [88] \\
\hline 378 & $\mathrm{H}+\mathrm{HO}_{2} \rightarrow \mathrm{H}_{2} \mathrm{O}+\mathrm{O}$ & $9.18 \mathrm{E}-11$ & 0 & 971.9 & & {$[88]$} \\
\hline 379 & $\mathrm{H}+\mathrm{HNO} \rightarrow \mathrm{H}_{2}+\mathrm{NO}$ & $2.35 \mathrm{E}-11$ & 0.94 & 249 & & [88] \\
\hline 380 & $\mathrm{H}+\mathrm{NO}+\mathrm{N}_{2} \rightarrow \mathrm{HNO}+\mathrm{N}_{2}$ & $7.32 \mathrm{E}-32$ & -1.318 & 184.3 & & {$[107]$} \\
\hline 381 & $\mathrm{H}+\mathrm{NO}+\mathrm{O}_{2} \rightarrow \mathrm{HNO}+\mathrm{O}_{2}$ & $7.32 \mathrm{E}-32$ & -1.318 & 184.3 & & {$[107]$} \\
\hline 382 & $\mathrm{H}+\mathrm{NO}_{3} \rightarrow \mathrm{NO}_{2}+\mathrm{OH}$ & $5.8 \mathrm{E}-10$ & 0 & 750 & & [69] \\
\hline 383 & $\mathrm{H}+\mathrm{H}_{2} \mathrm{O}_{2} \rightarrow \mathrm{OH}+\mathrm{H}_{2} \mathrm{O}$ & $4.0 \mathrm{E}-11$ & 0 & 2000 & & [88] \\
\hline 384 & $\mathrm{H}+\mathrm{H}_{2} \mathrm{O}_{2} \rightarrow \mathrm{H}_{2}+\mathrm{HO}_{2}$ & $8.0 \mathrm{E}-11$ & 0 & 4000 & & [88] \\
\hline 385 & $\mathrm{H}+\mathrm{CO}_{2} \rightarrow \mathrm{OH}+\mathrm{CO}$ & $2.51 \mathrm{E}-10$ & 0 & 13357 & $300-2500$ & {$[88]$} \\
\hline 386 & $\mathrm{H}+\mathrm{CO}+\mathrm{N}_{2} \rightarrow \mathrm{HCO}+\mathrm{N}_{2}$ & $1.9 \mathrm{E}-33$ & 0 & 842 & $300-2000$ & [88] \\
\hline 387 & $\mathrm{OH}+\mathrm{OH} \rightarrow \mathrm{H}_{2} \mathrm{O}+\mathrm{O}$ & $1.55 \mathrm{E}-13$ & 1.408 & -267.3 & $200-2500$ & [88] \\
\hline 388 & $\mathrm{OH}+\mathrm{O} \rightarrow \mathrm{O}_{2}+\mathrm{H}$ & $2.10 \mathrm{E}-11$ & -0.186 & 153.9 & $200-5000$ & [88] \\
\hline 389 & $\mathrm{OH}+\mathrm{H} \rightarrow \mathrm{H}_{2}+\mathrm{O}$ & $1.12 \mathrm{E}-14$ & 3.406 & 1233 & $300-2500$ & {$[88]$} \\
\hline 390 & $\mathrm{OH}+\mathrm{H}_{2} \rightarrow \mathrm{H}_{2} \mathrm{O}+\mathrm{H}$ & 2.31E-12 & 1.47 & 1761 & $200-3000$ & [88] \\
\hline 391 & $\mathrm{OH}+\mathrm{O}_{3} \rightarrow \mathrm{HO}_{2}+\mathrm{O}_{2}$ & $1.47 \mathrm{E}-12$ & 0 & 932.7 & $200-450$ & [88] \\
\hline 392 & $\mathrm{OH}+\mathrm{HO}_{2} \rightarrow \mathrm{H}_{2} \mathrm{O}+\mathrm{O}_{2}$ & $4.38 \mathrm{E}-11$ & 0 & -110.9 & $200-2550$ & {$[88]$} \\
\hline 393 & $\mathrm{OH}+\mathrm{OH}+\mathrm{N}_{2} \rightarrow \mathrm{H}_{2} \mathrm{O}_{2}+\mathrm{N}_{2}$ & $6.05 \mathrm{E}-31$ & -3 & 0 & $300-2500$ & {$[88]$} \\
\hline 394 & $\mathrm{OH}+\mathrm{OH}+\mathrm{O}_{2} \rightarrow \mathrm{H}_{2} \mathrm{O}_{2}+\mathrm{O}_{2}$ & $6.05 \mathrm{E}-31$ & -3 & 0 & $300-2500$ & {$[88]$} \\
\hline 395 & $\mathrm{OH}+\mathrm{OH}+\mathrm{H}_{2} \mathrm{O} \rightarrow \mathrm{H}_{2} \mathrm{O}_{2}+\mathrm{H}_{2} \mathrm{O}$ & $1.54 \mathrm{E}-31$ & -2.021 & -183.6 & & [88] \\
\hline 396 & $\mathrm{OH}+\mathrm{H}_{2} \mathrm{O}_{2} \rightarrow \mathrm{H}_{2} \mathrm{O}+\mathrm{HO}_{2}$ & $4.53 \mathrm{E}-12$ & 0 & 288.9 & $200-2500$ & {$[88]$} \\
\hline 397 & $\mathrm{OH}+\mathrm{HNO}_{2} \rightarrow \mathrm{H}_{2} \mathrm{O}+\mathrm{NO}_{2}$ & $1.8 \mathrm{E}-11$ & 0 & 390 & $280-430$ & {$[88]$} \\
\hline 398 & $\mathrm{OH}+\mathrm{N}_{2} \mathrm{O} \rightarrow \mathrm{HO}_{2}+\mathrm{N}_{2}$ & $3.69 \mathrm{E}-13$ & 0 & 2740 & $300-2700$ & {$[88]$} \\
\hline \multicolumn{7}{|c|}{ Humid air chemistry: ground neutrals (2) } \\
\hline 399 & $\mathrm{OH}+\mathrm{NO}+\mathrm{N}_{2} \rightarrow \mathrm{HNO}_{2}+\mathrm{N}_{2}$ & $7.4 \mathrm{E}-31$ & -2.4 & & $200-400$ & [95] \\
\hline 400 & $\mathrm{OH}+\mathrm{NO}+\mathrm{O}_{2} \rightarrow \mathrm{HNO}_{2}+\mathrm{O}_{2}$ & $7.4 \mathrm{E}-31$ & -2.4 & & $200-400$ & [95] \\
\hline 401 & $\mathrm{OH}+\mathrm{NO}_{2}+\mathrm{N}_{2} \rightarrow \mathrm{HNO}_{3}+\mathrm{N}_{2}$ & $2.6 \mathrm{E}-30$ & -2.9 & & $200-300$ & [95] \\
\hline 402 & $\mathrm{OH}+\mathrm{NO}_{2}+\mathrm{O}_{2} \rightarrow \mathrm{HNO}_{3}+\mathrm{O}_{2}$ & $2.2 \mathrm{E}-30$ & -2.9 & & $200-300$ & {$[95]$} \\
\hline 403 & $\mathrm{OH}+\mathrm{NO}_{3} \rightarrow \mathrm{HO}_{2}+\mathrm{NO}_{2}$ & $2.2 \mathrm{E}-11$ & & & & [108] \\
\hline 404 & $\mathrm{OH}+\mathrm{HNO} \rightarrow \mathrm{H}_{2} \mathrm{O}+\mathrm{NO}$ & $1.26 \mathrm{E}-11$ & 0.99 & 334.2 & $300-4000$ & [88] \\
\hline 405 & $\mathrm{OH}+\mathrm{HNO}_{3} \rightarrow \mathrm{H}_{2} \mathrm{O}+\mathrm{NO}_{3}$ & $7.2 \mathrm{E}-15$ & 0 & -785 & & [109] \\
\hline 406 & $\mathrm{OH}+\mathrm{N} \rightarrow \mathrm{NO}+\mathrm{H}$ & $3.92 \mathrm{E}-11$ & 0 & -72.3 & $250-515$ & {$[88]$} \\
\hline 407 & $\mathrm{OH}+\mathrm{CO} \rightarrow \mathrm{H}+\mathrm{CO}_{2}$ & $4.35 \mathrm{E}-14$ & 1.35 & -364.6 & $200-2200$ & [88] \\
\hline 408 & $\mathrm{HO}_{2}+\mathrm{O}_{3} \rightarrow \mathrm{OH}+2 \mathrm{O}_{2}$ & $1.66 \mathrm{E}-13$ & 0 & 1409.6 & $200-500$ & {$[88]$} \\
\hline 409 & $\mathrm{HO}_{2}+\mathrm{HO}_{2} \rightarrow \mathrm{H}_{2} \mathrm{O}_{2}+\mathrm{O}_{2}$ & $8.05 \mathrm{E}-11$ & -1.0 & & $300-2500$ & {$[88]$} \\
\hline 410 & $\mathrm{HO}_{2}+\mathrm{O} \rightarrow \mathrm{OH}+\mathrm{O}_{2}$ & $2.9 \mathrm{E}-11$ & 0 & -200 & $300-2500$ & [88] \\
\hline 411 & $\mathrm{HO}_{2}+\mathrm{NO} \rightarrow \mathrm{OH}+\mathrm{NO}_{2}$ & $3.6 \mathrm{E}-12$ & 0 & -240 & $230-2000$ & {$[88]$} \\
\hline 412 & $\mathrm{HO}_{2}+\mathrm{HO}_{2}+\mathrm{N}_{2} \rightarrow \mathrm{H}_{2} \mathrm{O}_{2}+\mathrm{O}_{2}+\mathrm{N}_{2}$ & $1.9 \mathrm{E}-33$ & 0 & -980 & & {$[95]$} \\
\hline 413 & $\mathrm{HO}_{2}+\mathrm{HO}_{2}+\mathrm{O}_{2} \rightarrow \mathrm{H}_{2} \mathrm{O}_{2}+2 \mathrm{O}_{2}$ & $1.9 \mathrm{E}-33$ & 0 & -980 & & [95] \\
\hline 414 & $\mathrm{HO}_{2}+\mathrm{NO} \rightarrow \mathrm{O}_{2}+\mathrm{HNO}$ & $9.1 \mathrm{E}-19$ & 0 & -2819 & $271-303$ & {$[88]$} \\
\hline 415 & $\mathrm{HO}_{2}+\mathrm{NO}_{2} \rightarrow \mathrm{HNO}_{2}+\mathrm{O}_{2}$ & $1.2 \mathrm{E}-13$ & & & & {$[88]$} \\
\hline 416 & $\mathrm{HO}_{2}+\mathrm{NO}_{3} \rightarrow \mathrm{HNO}_{3}+\mathrm{O}_{2}$ & $9.21 \mathrm{E}-13$ & & & & {$[88]$} \\
\hline 417 & $\mathrm{HO}_{2}+\mathrm{N} \rightarrow \mathrm{OH}+\mathrm{NO}$ & $2.19 \mathrm{E}-11$ & & & & [88] \\
\hline 418 & $\mathrm{HO}_{2}+\mathrm{CO} \rightarrow \mathrm{OH}+\mathrm{CO}_{2}$ & $2.51 \mathrm{E}-10$ & 0 & 11900 & $300-2500$ & [88] \\
\hline 419 & $\mathrm{~N}_{2} \mathrm{O}_{5}+\mathrm{H}_{2} \mathrm{O} \rightarrow 2 \mathrm{HNO}_{3}$ & $5.0 \mathrm{E}-19$ & & & & {$[108]$} \\
\hline 420 & $\mathrm{O}+\mathrm{H}_{2} \rightarrow \mathrm{OH}+\mathrm{H}$ & $9.0 \mathrm{E}-12$ & 1.0 & 4480 & & [69] \\
\hline 421 & $\mathrm{O}+\mathrm{H}_{2} \mathrm{O}_{2} \rightarrow \mathrm{OH}+\mathrm{HO}_{2}$ & $1.79 \mathrm{E}-13$ & 2.92 & 1394 & $200-2500$ & [88] \\
\hline 422 & $\mathrm{HNO}_{2}+\mathrm{O} \rightarrow \mathrm{OH}+\mathrm{NO}_{2}$ & $1.0 \mathrm{E}-12$ & 0 & 2000 & & [69] \\
\hline 423 & $\mathrm{HNO}_{3}+\mathrm{O} \rightarrow \mathrm{OH}+\mathrm{NO}_{3}$ & $1.0 \mathrm{E}-12$ & 0 & 4000 & & [69] \\
\hline 424 & $\mathrm{HNO}_{2}+\mathrm{NO}_{3} \rightarrow \mathrm{HNO}_{3}+\mathrm{NO}_{2}$ & $2.0 \mathrm{E}-15$ & & & & [88] \\
\hline 425 & $\mathrm{H}_{2} \mathrm{O}_{2}+\mathrm{NO}_{3} \rightarrow \mathrm{HO}_{2}+\mathrm{HNO}_{3}$ & $4.1 \mathrm{E}-16$ & & & & {$[110]$} \\
\hline \multicolumn{7}{|c|}{ Humid air chemistry: electronically excited neutrals } \\
\hline 426 & $\mathrm{~N}_{2}\left(A^{3} \Sigma_{\mathrm{u}}^{+}\right)+\mathrm{H}_{2} \mathrm{O} \rightarrow \mathrm{N}_{2}+\mathrm{H}+\mathrm{OH}$ & $5.0 \mathrm{E}-14$ & & & & {$[88]$} \\
\hline 427 & $\mathrm{~N}_{2}\left(a^{1} \Pi_{\mathrm{g}}\right)+\mathrm{H}_{2} \mathrm{O} \rightarrow \mathrm{N}_{2}+\mathrm{H}+\mathrm{OH}$ & $5.0 \mathrm{E}-14$ & & & & [88] \\
\hline 428 & $\mathrm{O}\left({ }^{1} \mathrm{D}\right)+\mathrm{H}_{2} \mathrm{O} \rightarrow \mathrm{OH}+\mathrm{OH}$ & $2.190 \mathrm{E}-10$ & & & $200-350$ & [88] \\
\hline 429 & $\mathrm{O}\left({ }^{1} \mathrm{D}\right)+\mathrm{H}_{2} \rightarrow \mathrm{OH}+\mathrm{H}$ & $1.1 \mathrm{E}-10$ & & & $200-350$ & [88] \\
\hline
\end{tabular}




\begin{tabular}{|c|c|c|c|c|c|c|c|}
\hline & Reaction & \multicolumn{2}{|l|}{$d$} & $e$ & $f$ & $T_{\mathrm{g}}(\mathrm{K})$ & References \\
\hline 430 & $\mathrm{O}\left({ }^{1} \mathrm{D}\right)+\mathrm{H}_{2} \mathrm{O} \rightarrow \mathrm{H}_{2}+\mathrm{O}_{2}$ & \multicolumn{2}{|c|}{$3.57 \mathrm{E}-10$} & & & $100-2100$ & [88] \\
\hline 431 & $\mathrm{O}\left({ }^{1} \mathrm{D}\right)+\mathrm{H}_{2} \mathrm{O}_{2} \rightarrow \mathrm{H}_{2} \mathrm{O}+\mathrm{O}_{2}$ & \multicolumn{2}{|c|}{$5.2 \mathrm{E}-10$} & & & & [88] \\
\hline 432 & $\mathrm{O}\left({ }^{1} \mathrm{~S}\right)+\mathrm{H}_{2} \mathrm{O} \rightarrow \mathrm{O}+\mathrm{H}_{2} \mathrm{O}$ & \multicolumn{2}{|c|}{$3.0 \mathrm{E}-10$} & & & & [111] \\
\hline 433 & $\mathrm{O}\left({ }^{1} \mathrm{~S}\right)+\mathrm{H}_{2} \mathrm{O} \rightarrow \mathrm{OH}+\mathrm{OH}$ & \multicolumn{2}{|c|}{$5.0 \mathrm{E}-10$} & & & & [111] \\
\hline 434 & $\mathrm{O}\left({ }^{1} \mathrm{~S}\right)+\mathrm{H}_{2} \mathrm{O} \rightarrow \mathrm{H}_{2}+\mathrm{O}_{2}$ & \multicolumn{2}{|c|}{$5.0 \mathrm{E}-10$} & & & & [111] \\
\hline 435 & $\mathrm{O}_{2}\left(a^{1} \Delta_{\mathrm{g}}\right)+\mathrm{H}_{2} \mathrm{O} \rightarrow \mathrm{O}_{2}+\mathrm{H}_{2} \mathrm{O}$ & \multicolumn{2}{|c|}{$3.0 \mathrm{E}-18$} & & & & [87] \\
\hline 436 & $\mathrm{O}_{2}\left(b^{1} \Sigma_{\mathrm{g}}^{+}\right)+\mathrm{H}_{2} \mathrm{O} \rightarrow \mathrm{O}_{2}+\mathrm{H}_{2} \mathrm{O}$ & \multicolumn{2}{|c|}{$6.7 \mathrm{E}-12$} & & & & {$[87]$} \\
\hline \multicolumn{8}{|c|}{ Humid air chemistry: ion-ion recombination } \\
\hline 437 & $\mathrm{H}_{3} \mathrm{O}^{+}+\mathrm{NO}_{2}^{-} \rightarrow \mathrm{H}_{2} \mathrm{O}+\mathrm{OH}+\mathrm{NO}$ & \multicolumn{2}{|c|}{$1.0 \mathrm{E}-6$} & & & & {$[112,113]$} \\
\hline 438 & $\mathrm{H}_{3} \mathrm{O}^{+}+\mathrm{O}_{3}^{-} \rightarrow \mathrm{H}_{2} \mathrm{O}+\mathrm{OH}+\mathrm{O}_{2}$ & \multicolumn{2}{|c|}{$1.0 \mathrm{E}-6$} & & & & {$[112,113]$} \\
\hline 439 & $\mathrm{H}_{3} \mathrm{O}^{+}+\mathrm{H}_{2} \mathrm{O}_{2}^{-} \rightarrow 2 \mathrm{H}_{2} \mathrm{O}+\mathrm{OH}$ & \multicolumn{2}{|c|}{$1.0 \mathrm{E}-6$} & & & & {$[112,113]$} \\
\hline 440 & $\mathrm{H}_{3} \mathrm{O}^{+}+\mathrm{H}_{2} \mathrm{O}_{3}^{-} \rightarrow 2 \mathrm{H}_{2} \mathrm{O}+\mathrm{HO}_{2}$ & \multicolumn{2}{|c|}{$1.0 \mathrm{E}-6$} & & & & {$[112,113]$} \\
\hline 441 & $\mathrm{H}_{3} \mathrm{O}^{+}+\mathrm{H}_{2} \mathrm{O}_{4}^{-} \rightarrow 2 \mathrm{H}_{2} \mathrm{O}+\mathrm{OH}+\mathrm{O}_{2}$ & \multicolumn{2}{|c|}{$1.0 \mathrm{E}-6$} & & & & {$[112,113]$} \\
\hline 442 & $\mathrm{H}_{3} \mathrm{O}^{+}+\mathrm{H}_{3} \mathrm{O}_{2}^{-} \rightarrow 3 \mathrm{H}_{2} \mathrm{O}$ & $1.0 \mathrm{H}$ & & & & & {$[112,113]$} \\
\hline 443 & $\mathrm{OH}^{+}+\mathrm{H}_{2} \mathrm{O}_{2}^{-} \rightarrow \mathrm{H}_{2} \mathrm{O}+\mathrm{HO}_{2}$ & $1.0 \mathrm{H}$ & & & & & {$[112,113]$} \\
\hline 444 & $\mathrm{OH}^{+}+\mathrm{H}_{2} \mathrm{O}_{3}^{-} \rightarrow \mathrm{H}_{2} \mathrm{O}+\mathrm{OH}+\mathrm{O}_{2}$ & $1.0 \mathrm{H}$ & & & & & {$[112,113]$} \\
\hline Hum & air chemistry: positive ions & & & & & & \\
\hline 445 & $\mathrm{O}^{+}+\mathrm{H}_{2} \rightarrow \mathrm{OH}^{+}+\mathrm{H}$ & 1.62 & -9 & & & & [114] \\
\hline 446 & $\mathrm{O}^{+}+\mathrm{H}_{2} \mathrm{O} \rightarrow \mathrm{H}_{2} \mathrm{O}^{+}+\mathrm{O}$ & $2.6 \mathrm{H}$ & & & & & [114] \\
\hline 447 & $\mathrm{~N}_{2}^{+}+\mathrm{H}_{2} \mathrm{O} \rightarrow \mathrm{H}_{2} \mathrm{O}^{+}+\mathrm{N}_{2}$ & $2.4 \mathrm{H}$ & & & & & [114] \\
\hline 448 & $\mathrm{~N}_{4}^{+}+\mathrm{H}_{2} \mathrm{O} \rightarrow \mathrm{H}_{2} \mathrm{O}^{+}+\mathrm{N}_{2}+\mathrm{N}_{2}$ & $3.0 \mathrm{H}$ & & & & & {$[102]$} \\
\hline 449 & $\mathrm{H}_{2} \mathrm{O}^{+}+\mathrm{O}_{2} \rightarrow \mathrm{H}_{2} \mathrm{O}+\mathrm{O}_{2}^{+}$ & $3.3 \mathrm{H}$ & -10 & & & & {$[114]$} \\
\hline 450 & $\mathrm{H}_{2} \mathrm{O}^{+}+\mathrm{H}_{2} \mathrm{O} \rightarrow \mathrm{H}_{3} \mathrm{O}^{+}+\mathrm{OH}$ & 1.85 & -9 & & & & [114] \\
\hline 451 & $\mathrm{OH}^{+}+\mathrm{O}_{2} \rightarrow \mathrm{OH}+\mathrm{O}_{2}^{+}$ & $3.8 \mathrm{H}$ & -10 & & & & [114] \\
\hline 452 & $\mathrm{H}_{2} \mathrm{O}^{+}+\mathrm{NO}_{2} \rightarrow \mathrm{H}_{2} \mathrm{O}+\mathrm{NO}_{2}^{+}$ & $1.2 \mathrm{H}$ & & & & & [114] \\
\hline 453 & $\mathrm{H}_{2} \mathrm{O}^{+}+\mathrm{NO} \rightarrow \mathrm{H}_{2} \mathrm{O}+\mathrm{NO}^{+}$ & $4.6 \mathrm{H}$ & & & & & [114] \\
\hline Hum & air chemistry: negative ions & & & & & & \\
\hline 454 & $\mathrm{O}^{-}+\mathrm{H}_{2} \rightarrow \mathrm{H}_{2} \mathrm{O}+\mathrm{e}$ & $7.0 \mathrm{H}$ & -10 & & & & [69] \\
\hline 455 & $\mathrm{O}_{2}^{-}+\mathrm{H}_{2} \mathrm{O} \rightarrow \mathrm{O}_{2}+\mathrm{H}_{2} \mathrm{O}+\mathrm{e}$ & $5.0 \mathrm{H}$ & & 0 & 5000 & & {$[100]$} \\
\hline 456 & $\mathrm{OH}^{-}+\mathrm{O}_{3} \rightarrow \mathrm{OH}+\mathrm{O}_{3}^{-}$ & $9.0 \mathrm{H}$ & -10 & 0.5 & & & {$[101]$} \\
\hline 457 & $\mathrm{OH}^{-}+\mathrm{O} \rightarrow \mathrm{HO}_{2}+\mathrm{e}$ & $4.0 \mathrm{~F}$ & -10 & 0.5 & & & {$[101]$} \\
\hline 458 & $\mathrm{H}^{-}+\mathrm{H}_{2} \mathrm{O} \rightarrow \mathrm{OH}^{-}+\mathrm{H}_{2}$ & $1.0 \mathrm{H}$ & & & & & [69] \\
\hline 459 & $\mathrm{H}_{2} \mathrm{O}_{2}^{-}+\mathrm{O}_{2} \rightarrow \mathrm{H}_{2} \mathrm{O}+\mathrm{O}_{3}^{-}$ & $6.2 \mathrm{H}$ & -11 & & & & {$[102]$} \\
\hline 460 & $\mathrm{H}_{2} \mathrm{O}_{2}^{-}+\mathrm{H}_{2} \mathrm{O} \rightarrow \mathrm{H}_{3} \mathrm{O}_{2}^{-}+\mathrm{OH}$ & $1.0 \mathrm{H}$ & -11 & & & & {$[115]$} \\
\hline 461 & $\mathrm{O}^{-}+\mathrm{H}_{2} \mathrm{O}+\mathrm{N}_{2} \rightarrow \mathrm{H}_{2} \mathrm{O}_{2}^{-}+\mathrm{N}_{2}$ & $1.3 \mathrm{H}$ & -28 & & & & {$[115]$} \\
\hline 462 & $\mathrm{O}^{-}+\mathrm{H}_{2} \mathrm{O}+\mathrm{O}_{2} \rightarrow \mathrm{H}_{2} \mathrm{O}_{2}^{-}+\mathrm{O}_{2}$ & $1.3 \mathrm{H}$ & -28 & & & & [115] \\
\hline 463 & $\mathrm{O}_{2}^{-}+\mathrm{H}_{2} \mathrm{O}+\mathrm{N}_{2} \rightarrow \mathrm{H}_{2} \mathrm{O}_{3}^{-}+\mathrm{N}_{2}$ & $2.2 \mathrm{H}$ & -28 & & & & {$[115]$} \\
\hline 464 & $\mathrm{O}_{2}^{-}+\mathrm{H}_{2} \mathrm{O}+\mathrm{O}_{2} \rightarrow \mathrm{H}_{2} \mathrm{O}_{3}^{-}+\mathrm{O}_{2}$ & $2.2 \mathrm{H}$ & -28 & & & & {$[115]$} \\
\hline 465 & $\mathrm{O}_{3}^{-}+\mathrm{H}_{2} \mathrm{O}+\mathrm{N}_{2} \rightarrow \mathrm{H}_{2} \mathrm{O}_{4}^{-}+\mathrm{N}_{2}$ & $2.7 \mathrm{E}$ & -28 & & & & {$[115]$} \\
\hline 466 & $\mathrm{O}_{3}^{-}+\mathrm{H}_{2} \mathrm{O}+\mathrm{O}_{2} \rightarrow \mathrm{H}_{2} \mathrm{O}_{4}^{-}+\mathrm{O}_{2}$ & $2.7 \mathrm{E}$ & -28 & & & & {$[115]$} \\
\hline 467 & $\mathrm{OH}^{-}+\mathrm{H}_{2} \mathrm{O}+\mathrm{N}_{2} \rightarrow \mathrm{H}_{3} \mathrm{O}_{2}^{-}+\mathrm{N}_{2}$ & $2.5 \mathrm{H}$ & -28 & & & & {$[115]$} \\
\hline 468 & $\mathrm{OH}^{-}+\mathrm{H}_{2} \mathrm{O}+\mathrm{O}_{2} \rightarrow \mathrm{H}_{3} \mathrm{O}_{2}^{-}+\mathrm{O}_{2}$ & $2.5 \mathrm{~F}$ & -28 & & & & {$[115]$} \\
\hline 469 & $\mathrm{O}_{2}^{-}+\mathrm{HNO}_{3} \rightarrow \mathrm{NO}_{3}^{-}+\mathrm{HO}_{2}$ & $2.9 \mathrm{H}$ & & & & & {$[102]$} \\
\hline 470 & $\mathrm{H}_{2} \mathrm{O}_{3}^{-}+\mathrm{NO}_{2} \rightarrow \mathrm{NO}_{2}^{-}+\mathrm{H}_{2} \mathrm{O}+\mathrm{O}_{2}$ & $9.0 \mathrm{H}$ & -10 & & & & {$[102]$} \\
\hline 471 & $\mathrm{H}_{2} \mathrm{O}_{3}^{-}+\mathrm{NO} \rightarrow \mathrm{NO}_{3}^{-}+\mathrm{H}_{2} \mathrm{O}$ & $3.1 \mathrm{H}$ & -10 & & & & {$[102]$} \\
\hline 472 & $\mathrm{H}_{2} \mathrm{O}_{3}^{-}+\mathrm{O}_{3} \rightarrow \mathrm{O}_{3}^{-}+\mathrm{H}_{2} \mathrm{O}+\mathrm{O}_{2}$ & $8.0 \mathrm{H}$ & -10 & & & & {$[102]$} \\
\hline 473 & $\mathrm{H}_{2} \mathrm{O}_{4}^{-}+\mathrm{CO}_{2} \rightarrow \mathrm{CO}_{3}^{-}+\mathrm{H}_{2} \mathrm{O}+\mathrm{O}_{2}$ & $1.8 \mathrm{H}$ & -10 & & & & {$[115]$} \\
\hline 474 & $\mathrm{H}_{2} \mathrm{O}_{3}^{-}+\mathrm{CO}_{2} \rightarrow \mathrm{CO}_{4}^{-}+\mathrm{H}_{2} \mathrm{O}$ & $5.8 \mathrm{H}$ & -10 & & & & {$[115]$} \\
\hline 475 & $\mathrm{CO}_{3}^{-}+\mathrm{HNO}_{3} \rightarrow \mathrm{NO}_{3}^{-}+\mathrm{CO}_{2}+\mathrm{OH}$ & 3.51 & -10 & & & & {$[102]$} \\
\hline & Reaction & & $A\left(\mathrm{~s}^{-1}\right)$ & & $\lambda(\mathrm{nm})$ & $\kappa$ & References \\
\hline Radi & ive processes & & & & & & \\
\hline 476 & $\begin{array}{l}\mathrm{N}_{2}\left(B^{3} \Pi_{\mathrm{g}}\left(v^{\prime}=6,7,6,7\right)\right) \rightarrow \mathrm{N}_{2}\left(A^{3} \Sigma\right. \\
\left.\quad\left(v^{\prime \prime}=3,4,2,3\right)\right)+h v_{1}\end{array}$ & & $1.34 \mathrm{E}+5$ & & $\begin{array}{l}662.3 ; 654.48 \\
606.9 ; 601.3\end{array}$ & 1 & [69] \\
\hline 477 & $\begin{array}{l}\mathrm{N}_{2}\left(C^{3} \Pi_{\mathrm{u}}\left(v^{\prime}=0,1,1,2\right)\right) \rightarrow \mathrm{N}_{2}\left(B^{3} \mathrm{I}\right. \\
\left.\quad\left(v^{\prime \prime}=4,5,4,6\right)\right)+h v_{2}\end{array}$ & & $2.45 \mathrm{E}+7$ & & $\begin{array}{l}434.36 ; 426.97 \\
399.80 ; 420.05\end{array}$ & 1 & [69] \\
\hline 478 & $\mathrm{~N}_{2}^{+}\left(B^{2} \Sigma_{\mathrm{u}}^{+}\left(v^{\prime}=0\right)\right) \rightarrow \mathrm{N}_{2}^{+}\left(X^{2} \Sigma_{\mathrm{g}}^{+}\left(v^{\prime \prime}=\right.\right.$ & $h v_{3}$ & $1.58 \mathrm{E}+7$ & & 427.80 & 1 & [116] \\
\hline 479 & $\mathrm{NO}\left(A^{2} \Sigma^{+}\left(v^{\prime}=0\right)\right) \rightarrow \mathrm{NO}\left(X^{2} \Pi_{\mathrm{r}}\left(v^{\prime \prime}\right.\right.$ & $+h v_{4}$ & $5.0 \mathrm{E}+6$ & & 227.0 & 1 & [116] \\
\hline 480 & $\mathrm{CO}_{2}\left(\begin{array}{lll}0 & 0 & 1\end{array}\right) \rightarrow \mathrm{CO}_{2}\left(\begin{array}{lll}1 & 0 & 0\end{array}\right)+h \nu_{5}$ & & 0.2 & & 9400.0 & 1 & [116] \\
\hline 481 & $\mathrm{CO}_{2}\left(\begin{array}{lll}0 & 0 & 1\end{array}\right) \rightarrow \mathrm{CO}_{2}+h v_{6}$ & & 450 & & 4260.0 & 1 & [116] \\
\hline 482 & $\mathrm{CO}_{2}(100) \rightarrow \mathrm{CO}_{2}(010)+h v_{7}$ & & 2.08 & & 13900.0 & 1 & [116] \\
\hline 483 & $\mathrm{CO}_{2}(010) \rightarrow \mathrm{CO}_{2}+h v_{8}$ & & 1.56 & & 14900.0 & 1 & [116] \\
\hline 484 & $\mathrm{O}\left({ }^{1} \mathrm{D}\right) \rightarrow \mathrm{O}+h v_{9}$ & & $5.1 \mathrm{E}-3$ & & 630.0 & 1 & [117] \\
\hline 485 & $\mathrm{O}\left({ }^{1} \mathrm{~S}\right) \rightarrow \mathrm{O}\left({ }^{1} \mathrm{D}\right)+h v_{10}$ & & 1.34 & & 557.7 & 1 & [117] \\
\hline 486 & $\mathrm{~N}_{2}\left(a^{1} \Pi_{\mathrm{g}}\left(v^{\prime}=0\right)\right) \rightarrow \mathrm{N}_{2}\left(X^{1} \Sigma_{\mathrm{g}}^{+}\left(v^{\prime \prime}=\right.\right.$ & $h v_{11}$ & $8.55 \mathrm{E}+3$ & & 155.2 & 1 & {$[69]$} \\
\hline
\end{tabular}




\section{References}

[1] Wilson C T R 1925 Proc. Phys. Soc. Lond. 37 32D

[2] Neubert T 2003 Science 300 747-9

[3] Pasko V P 2003 Nature 423 927-9

[4] Franz R C 1990 Science 24948

[5] Sentman D D, Westcott E M, Osborne D L, Hampton D L and Heavner M J 1995 Geophys. Res. Lett. 22 1205-8

[6] Rairden R L and Mende S B 1995 Geophys. Res. Lett. 223465

[7] Lyons W A 1996 J. Geophys. Res. 101 29641-52

[8] Winckler J R, Lyons W A, Nelson T E and Nemzek R J 1996 J. Geophys. Res. 1016997

[9] Stanley M, Krehbiel P, Brook M, Moore C, Rison W and Abrahams B 1999 Geophys. Res. Lett. 26 3201-4

[10] Gerken E A, Inan U S and Barrington-Leigh C P 2000 Geophys. Res. Lett. 27 2637-40

[11] Barrington-Leigh C P, Inan U S and Stanley M 2001 J. Geophys. Res. 106 1741-50

[12] Vaughan O H Jr, Blakeslee R J, Boeck W L, Vonnegut B, Brook M and McKune J 1992 Mon. Weather Rev. 1201459

[13] Boeck W L, Vaughan O H Jr, Blakeslee R J,Vonnegut B, Brook M and McKune J 1995 J. Geophys. Res. 1001465

[14] Boeck W L, Vaughan O H Jr, Blakeslee R J, Vonnegut B and Brook M 1998 J. Atmos. Sol. Terr. Phys. 60 669-77

[15] Blanc E, Farges T, Roche R, Brebion D, Hua T, Labarthe A and Melnikov V 2004 J. Geophys. Res. 109 A02306

[16] Yair Y, Israelevich P, Devir A D, Moalem M, Price C Joseph J H, Levin Z, Ziv A, Sternlieb A and Teller A 2004 J. Geophys. Res. 109 D15201

[17] Kuo C L, Hsu R R, Chen A B, Su H T, Lee L C, Mende S B, Frey H U, Fukunishi H and Takahashi Y 2005 Geophys. Res. Lett. 32 L19103

[18] Liu N et al 2006 Geophys. Res. Lett. 33 L01101

[19] Mende S B, Frey H U, Hsu R R, Su H T, Chen A B, Lee L C, Sentman D D, Takahashi Y and Fukunishi H 2005 J. Geophys. Res. 110 A11312

[20] Adachi T, Fukunishi H, Takahashi Y, Hiraki Y, Hsu R R, Su H T, Chen A B, Mende S B, Frey H U and Lee L C 2006 Geophys. Res. Lett. 3317803

[21] http://smsc.cnes.fr/TARANIS/index.htm

[22] http://spacecenter.dk/research/solarphysics/asim/asim

[23] Gerken E A and Inan U S 2003 J. Atmos. Sol. Terr. Phys. 65 567-72

[24] Gerken E A and Inan U S 2005 IEEE Trans. Plasma Sci. 33 282-3

[25] Marshall R A and Inan U S 2005 Geophys. Res. Lett. 32 L05804

[26] Marshall R A and Inan U S 2006 Radio Sci. 41 RS6S43

[27] Cummer S A, Jaugey N C, Li J B, Lyons W A, Nelson T E and Gerken E A 2006 Geophys. Res. Lett. 33 L04104

[28] McHarg M G, Stenbaek-Nielsen H C and Kammae T 2007 Geophys. Res. Lett. 34 L06804

[29] Stenbaek-Nielsen H C, McHarg M G, Kanmae T and Sentman D D 2007 Geophys. Res. Lett. 34 L11105

[30] Raizer Y P, Milikh G M, Schneider M N and Novakovski S V 1998 J. Phys. D: Appl. Phys. 31 3255-64

[31] Raizer Y P 1991 Gas Discharge Physics (New York: Springer)

[32] Mende S B, Rairden R L, Swenson G R and Lyons W A 1995 Geophys. Res. Lett. 22 2633-6

[33] Hampton D L, Heavner M J, Wescott E M and Sentman D D 1996 Geophys. Res. Lett. 23 89-92

[34] Taranenko Y N, Inan U S and Bell T F 1993 Geophys. Res. Lett. 20 1539-42

[35] Taranenko Y N, Inan U S and Bell T F 1993 Geophys. Res. Lett. $202675-8$

[36] Pasko V P, Inan U S, Bell T F and Taranenko Y N 1997 J. Geophys. Res. 102 4529-61
[37] Heavner M J, Sentman D D, Moudry D R, Wescott E M, Siefring C L, Morril J S and Bucsela E 2000 Sprites, Blue Jets, and Elves: Optical Evidence of Energy Transport Across the Stratopause ed D E Siskind et al (Washington, DC: American Geophysical Union) pp 69-82

[38] Armstrong R A, Shorter J, Taylor M, Suszcynsky D M, Lyons W and Jeong L 1998 J. Atmos. Sol. Terr. Phys. $60787-99$

[39] Armstrong R A, Suszcynsky D M, Lyons W A and Nelson T E 2000 Geophys. Res. Lett. 27 653-6

[40] Morrill J S et al 2002 Geophys. Res. Lett. 291462

[41] Bucsela E, Morrill J S, Heavner M J, Siefring C L, Berg S L, Hampton D, Moudry D R, Wescott E M and Sentman D D 2003 J. Atmos. Sol. Terr. Phys. 65 583-90

[42] Green B D, Fraser M E, Rawlins W T, Jeong L, Blumberg W A M, Mende S B, Swenson G R, Hampton D L, Wescott E M and Sentman D D 1996 Geophys. Res. Lett. 23 2161-4

[43] Morrill J S, Bucsela E J, Pasko V P, Berg S L, Benesch W M, Wescott E M and Heavner M J 1998 J. Atmos. Sol. Terr. Phys. 60 811-29

[44] Milikh G, Valdivia J A and Papadopoulos K 1998 J. Atmos. Sol. Terr. Phys. 60 907-15

[45] Picard R H, Inan U S, Pasko V P, Winick J R and Wintersteiner P P 1997 Geophys. Res. Lett. 24 2635-8

[46] Milikh G M, Usikov D A and Valdivia J A 1998 J. Atmos. Sol. Terr. Phys. 60 895-905

[47] Liu N and Pasko V P 2005 Geophys. Res. Lett. 32 L05104

[48] Liu N and Pasko V P 2007 Geophys. Res. Lett. 34 L16103

[49] Mende S, Frey H, Hsu R R, Su H T, Chen A, Lee L C, Fukunishi H and Takahashi Y 2004 EOS Trans. Am. Geophys. Uuion 85 (Fall Meet. Suppl.) Abstract AE51A-02

[50] Sentman D D and Wescott E M 1995 Phys. Plasmas 2 2514-22

[51] Stenbaek-Nielsen H C, Moudry D R, Wescott E M, Sentman D D and Sabbas F T S 2000 Geophys. Res. Lett. 27 3829-32

[52] Mishin E 1997 Geophys. Res. Lett. 24 1919-22

[53] Armstrong R A, Suszynsky D M, Lyons W A and Williams E R 2001 National Radio Science Meeting (URSI) (Boulder, CO)

[54] Baehr J, Schlager H, Ziereis H, Stock P, van Velthoven P, Busen R, Ström J and Schumann U 2003 Geophys. Res. Lett. 301598

[55] Sentman D D, Moudry D R, Stenbaek-Nielsen H C, Wescott E M and Sao Sabbas F T 2000 EOS Trans. Am. Geophys. Union (Fall Meeting Suppl.) Abstract A11E-01

[56] Hiraki Y, Tong L, Fukunishi H, Nanbu K, Kasai Y and Ichimura A 2004 Geophys. Res. Lett. 31 L14105

[57] Sentman D D, Stenbaek-Nielsen H C, McHarg M G and Morrill J S 2008 J. Geophys. Res. 13 D1112

[58] Enell C F et al 2008 Ann. Geophys. 26 13-27

[59] Hiraki Y, Kasai Y and Fukunishi H 2008 Atmos. Chem. Phys. 8 2311-36

[60] Arnone E, Kero A, Dinelli B M, Enell C F, Arnold N F, Papandrea E, Rodger C J, Carlotti M, Ridolfi M and Turunen E 2008 Geophys. Res. Lett. 35 L05807

[61] Kulikovsky A A 1997 IEEE Trans. Plasma Sci. 25 439-47

[62] Morgan W L and Penetrante B M 1990 Comput. Phys. Comm. 58 127-52

[63] Hindmarsh A C 1983 Scientific Computing, Applications of Mathematics and Computing to the Physical Sciences vol 1 ed R S Stepleman et al (Amsterdam: North Holland) pp 55-64

[64] Radhakrishnan K and Hindmarsh A C 1993 LLNL Report UCRL-ID-113855

[65] https://computation.llnl.gov/casc/software.html 
[66] Gear C W 1971 Numerical Initial Value Problems in Ordinary Differential Equations (Englewood Cliffs, NJ: Prentice-Hall)

[67] Liu N and Pasko V P 2004 J. Geophys. Res. 109 A04301

[68] Bourdon A, Pasko V P, Liu N Y, Célestin S, Ségur P and Marode E 2007 Plasma Sources. Sci. Technol. 16 656-78

[69] Capitelli M, Ferreira C M, Gordiets B F and Osipov A I 2000 Plasma Kinetics in Atmospheric Gases (Berlin: Springer)

[70] Collins W D et al 2004 Description of the NCAR Community Atmospheric Model (CAM3) (Boulder, CO: National Center for Atmospheric Research)

[71] http://www.ccsm.ucar.edu/models/atm-cam/

[72] http://jilawww.colorado.edu/avp/collision_data/

[73] Christophorou L G 1984 Electron-Molecule Interactions and Their Applications vol 1 (New York: Academic) p 376

[74] Skalny J D, Matejcik S, Kiendler A, Stamatovic A and Märck T D 1996 Chem. Phys. Lett. 255 112-8

[75] Brook E, Harrison M F A and Smith A C H 1978 J. Phys. B: At. Mol. Phys. 11 3115-32

[76] Majeed T and Strickland D J 1997 J. Phys. Chem. Ref. Data 26 335-49

[77] Hayashi M 1990 Nonequilibrium Processes in Partially Ionized Gases (NATO ASI Series vol B220) ed M Capitelli and J N Bardsley (New York: Plenum) p 333

[78] Itikawa Y and Mason N 2005 J. Phys. Chem. Ref. Data $341-22$

[79] Yousfi M and Benabdessadok M D 1996 J. Appl. Phys. 80 6619-30

[80] Castillo M, Méndez I, Islyaikin A M, Herrero V J and Tanarro I 2005 J. Phys. Chem. A 109 6255-63

[81] Castillo M 2004 Spectrometry and kinetics of cold plasmas of nitrogen oxides and air $P h D$ Thesis

[82] Gudmundsson J T, Kouznetsov I G, Patel K K and Lieberman M A 2000 J. Phys. D: Appl. Phys. 34 1100-9

[83] Kossyi I A, Kostinsky A Y, Matveyev A A and Silakov V P 1992 Plasma Sources Sci. Technol. 1 207-20

[84] Peverall R et al 2001 J. Chem. Phys. 114 6679-89

[85] Whitaker M, Biondi M A and Johnsen R 1981 Phys. Rev. A $24743-5$

[86] Kruger V and Olander D R 1976 J. Phys. Chem. 80 1676-84

[87] Starikovskaia S M, Starikovskii A Y and Zatsepin D V 2001 Combust. Theory Modelling 5 91-129

[88] NIST Chemical Kinetics Database http://kinetics.nist.gov/ kinetics/index.jsp

[89] Cacciatore M, Kurnosov A and Napartovich A 2005 J. Chem. Phys. 123174315

[90] Moore C B, Wood R E, Hu B L and Yardley J T 1967 J. Chem. Phys. 46 4222-31

[91] Kurnosov A, Napartovich A, Shnyrev S and Cacciatore M 2007 J. Phys. Chem A 111 7057-65

[92] Piper L G, Velazco J E and Setser D W 1973 J. Chem. Phys. $593323-40$

[93] Bourène M and Le Calvé J 1973 J. Chem. Phys. 58 1452-8

[94] Gordiets B F, Ferreira C M, Guerra V L, Loureiro J M A H, Nahorny J, Pagnon D, Touzeau M and Vialle M 1995 IEEE Trans. Plasma Sci. 23 750-67
[95] Atkinson R, Baulch D L, Hampson R F Jr, Kerr J A and Troe J 1989 J. Phys. Chem. Ref. Data 18 881-1097

[96] Simek M 2003 Plasma Sources Sci. Technol. 12 421-31

[97] Thoman J W Jr, Gray J A, Durant J L Jr and Paul P H 1992 J. Chem. Phys. 97 8156-63

[98] Lindinger W, Howorka F, Lukac P, Kuhn S, Villinger H, Alge E and Ramler H 1981 Phys. Rev. A 23 2319-26

[99] Midey A J, Williams S, Miller T M, Larsen P T and Viggiano A A 2002 J. Phys. Chem. A 106 11739-42

[100] Bortner M H and Baurer T (ed) 1972 Defense Nuclear Agency Reaction Rate Handbook 2nd edn (ref. DNA1948H) (Washington, DC: Defense Nuclear Agency)

[101] Brasseur G and Solomon S 1986 Aeronomy of the Middle Atmosphere 2nd edn (Dordrecht: Reidel)

[102] Kazil J 2002 The University of Bern Atmospheric Ion Model: time-dependent ion modeling in the stratosphere, mesosphere and lower thermosphere $P h D$ Thesis

[103] Albritton D L 1978 At. Data Nucl. Data Tables 22 1-101

[104] GRI-MECH 3 Reaction Rate Database http://www.me.berkeley.edu/gri-mech/

[105] Baulch D L, Cox R A, Hampson Jt. R F, Kerr J A, Troe J and Watson R T 1984 J. Phys. Chem. Ref. Data 13 1259-378

[106] Ko T and Fontijn A 1991 J. Phys. Chem. 95 3984-7

[107] Tsang W and Herron J T 1991 J. Phys. Chem. Ref. Data 20 609-63

[108] Sander S P (ed) 2006 Chemical kinetics and photochemical data for use in atmospheric studies, evaluation number 15 JPL Publication No 06-2, 2006 (electronic copies can be downloaded from http://jpldataeval.jpl.nasa.gov/)

[109] Brasseur G and Solomon S 2005 Aeronomy of the Middle Atmosphere 3rd edn (Dordrecht: Springer)

[110] Simpson D 1995 J. Geophys. Res. 100 22891-906

[111] Slanger T G and Black G 1978 J. Chem. Phys. 68 989-97

[112] McGowan S 1965 Phys. Med. Biol. 10 25-40

[113] McGowan S 1967 Can. J. Phys. 45 439-48

[114] Anicich V G 1993 J. Phys. Chem. Ref. Data 22 1469-569

[115] Fritzenwallner J and Kopp E 1998 Adv. Space Res. 21 891-4

[116] Radzig A A and Smirnov B M 1985 Reference Data on Atoms, Molecules and Ions (Berlin: Springer)

[117] Wiese W L, Smith M W and Glennon B M 1966 Atomic Transition Probabilities: Hydrogen through Neon NSRDS-NBS 4 vol 1 (Washington, DC: National Bureau of Standards)

[118] Siskind D E and Summers M E 1998 Geophys. Res. Lett. $252133-6$

[119] Hale L C 1994 J. Geophys. Res. 99 21089-96

[120] Hunten D M, Roach F M and Chamberlain J W 1956 J. Atmos. Terr. Phys. 8 345-6

[121] De Benedictis S and Dilecce G 1996 J. Physique III 6 1189-204

[122] De Benedictis S, Dilecce G and Simek M 1997 J. Phys. D: Appl. Phys. 30 2887-94

[123] Simek M, Babický V, Clupek M, De Benedictis S, Dilecce G and Sunka P 1998 J. Phys. D: Appl. Phys. 31 2591-602

[124] Simek M 2002 J. Phys. D: Appl. Phys. 35 1967-80 